\title{
A De Novo Enantioselective Total Synthesis of Laulimalide
}

\author{
Scott G. Nelson,* Wing S. Cheung, Andrew J. Kassick, and Mark A. Hilfiker \\ Department of Chemistry, University of Pittsburgh, Pittsburgh, Pennsylvania 15260

\section{Supporting Information}

General Information: Optical rotations were measured on a Perkin-Elmer 241 digital polarimeter with a sodium lamp at ambient temperature and are reported as follows: $[\alpha]_{\lambda}(c \mathrm{~g} / 100 \mathrm{~mL})$. Infrared spectra were recorded on a Nicolet Avatar 360 FT-IR spectrometer. ${ }^{1} \mathrm{H}$ NMR spectra were recorded on Bruker DPX 301/302 (300 MHz), Avance 500 (500 MHz), or LC-NMR $600(600 \mathrm{MHz})$ spectrometers. Chemical shifts are reported in ppm from tetramethylsilane with the solvent resonance as the internal standard $\left(\mathrm{CHCl}_{3}: \delta 7.26 \mathrm{ppm}\right)$. Data are reported as follows: chemical shift, multiplicity ( $\mathrm{s}=$ singlet, $\mathrm{d}=$ doublet, $\mathrm{t}=$ triplet, $\mathrm{q}=$ quartet, $\mathrm{br}=$ broad, $\mathrm{m}=$ multiplet $)$, coupling constants $(\mathrm{Hz})$, integration. ${ }^{13} \mathrm{C}$ NMR spectra were recorded on a Bruker DPX 301/302 (75 MHz) or Avance 500 (125 $\mathrm{MHz})$ spectrometers with complete proton decoupling. Chemical shifts are reported in ppm from tetramethylsilane with the solvent as the internal standard (deuterochloroform: $\delta 77.0 \mathrm{ppm}$ ). Mass spectra were obtained on a VG-7070 or Fisons Autospec high resolution magnetic sector mass spectrometer. Analytical thin layer chromatography was performed on EM Reagent $0.25 \mathrm{~mm}$ silica gel $60-\mathrm{F}$ plates. Flash chromatography was performed as previously described on 230-240 mesh silica gel. ${ }^{1}$ Analytical gas liquid chromatography (GLC) was performed on a Hewlet-Packard 5890 Series II gas chromatograph with a flame ionization detector and split mode capillary injection system, using a Chiraldex $^{\text {TM }}$ G-TA column $(20 \mathrm{~m}$ x $0.25 \mathrm{~mm}$ ) (Advanced Separation Technologies Inc.). Hydrogen was used as the carrier gas at the indicated pressures. Analytical high performance liquid chromatograph (HPLC) was performed on a Hewlett Packard 1100 liquid chromatograph equipped with a variable wavelength UV detector (deuterium lamp, 190-600 nm), using a Daicel Chiralcel ${ }^{\mathrm{TM}}$ OD-H column $(250 \times 4.6 \mathrm{~mm})$ (Daicel Inc.). HPLC grade isopropanol and hexanes were used as the eluting solvents.

All experiments were carried out under a nitrogen atmosphere in oven or flame-dried glassware using standard inert atmosphere techniques for introducing reagents and solvents. Commercially available solvents and reagents were purified and dried using standard procedures. The catalyst complex 4 was prepared according to the published procedure. ${ }^{2}$

$\mathrm{O}_{\mathrm{O}} \quad$ (4R)-4-Methyloxetan-2-one (5): To a $-78{ }^{\circ} \mathrm{C}$ solution of $1.3 \mathrm{~g}$ of aluminum complex 4 $(2.27 \mathrm{mmol})$ and $14.6 \mathrm{~g}$ of tetra- $n$-butylammonium bromide $(45.4 \mathrm{mmol})$ in $91 \mathrm{~mL}$ of $\mathrm{CH}_{2} \mathrm{Cl}_{2}$ was added $6.72 \mathrm{~mL}$ of ${ }^{i} \operatorname{Pr}_{2} \mathrm{NEt}(38.6 \mathrm{mmol})$ followed by $3.20 \mathrm{~mL}$ of acetyl bromide (43.1 mmol). The resulting yellow solution was stirred two minutes at $-78{ }^{\circ} \mathrm{C}$ whereupon $1.27 \mathrm{~mL}$ of acetaldehyde $(22.7 \mathrm{mmol})$ was added dropwise via syringe. The reaction was maintained at $-78{ }^{\circ} \mathrm{C}$ for $12 \mathrm{~h}$ before the reaction mixture was poured into ice-cold hexanes $(300 \mathrm{~mL})$. The resulting mixture was eluted through silica gel $(40 \% \mathrm{EtOAc} / \mathrm{Hex})$ and the eluant was concentrated to yield $1.7 \mathrm{~g}(87 \%$, crude) of $\mathbf{5}$ as a pale yellow liquid that was sufficiently pure to use in subsequent transformations. Separation of the enantiomers by chiral GC [Chiraldex G-TA column, flow rate $1.5 \mathrm{~mL} / \mathrm{min}$, method: $80{ }^{\circ} \mathrm{C}$ for $5.0 \mathrm{~min}$, ramp @ $5.0{ }^{\circ} \mathrm{C} / \mathrm{min}$ to $100{ }^{\circ} \mathrm{C}$ for $10.0 \mathrm{~min}$, ramp $@ 5.0{ }^{\circ} \mathrm{C}$ to $130{ }^{\circ} \mathrm{C}$ for $5 \mathrm{~min}$. $\mathrm{T}_{\mathrm{r}} 8.04 \mathrm{~min}(R)$ and $9.05 \mathrm{~min}(S)$ ] determined the enantiomeric excess to be $99 \%$. ${ }^{1} \mathrm{H} \mathrm{NMR}(300 \mathrm{MHz}$,

Still, W. C.; Kahn, M.; Mitra, A. J. Org. Chem. 1978, 43, 2923-2925.

Nelson, S. G.; Peelen, T. J.; Wan, Z. J. Am. Chem. Soc. 1999, 121, 9742-9743. 
$\left.\mathrm{CDCl}_{3}\right): \delta 4.61(\mathrm{ddq}, J=4.2,6.0,12.0 \mathrm{~Hz}, 1 \mathrm{H}), 3.48(\mathrm{dd}, J=5.7,16.3 \mathrm{~Hz}, 1 \mathrm{H}), 2.98(\mathrm{dd}, J=4.3,16.3$ $\mathrm{Hz}, 1 \mathrm{H}), 1.47(\mathrm{~d}, J=8.2 \mathrm{~Hz}, 3 \mathrm{H}) .{ }^{13} \mathrm{C} \mathrm{NMR}\left(75 \mathrm{MHz}, \mathrm{CDCl}_{3}\right): \delta 168.0,67.7,44.0,20.2$.

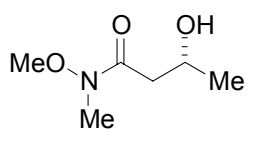

(3R)-3-Hydroxy- $N$-methoxy- $N$-methylbutyramide: To a $0{ }^{\circ} \mathrm{C}$ solution of $6.32 \mathrm{~g}$ of $\mathrm{N}, \mathrm{O}$-dimethylhydroxylamine hydrochloride $(65.1 \mathrm{mmol})$ in $30 \mathrm{~mL} \mathrm{CH}_{2} \mathrm{Cl}_{2}$ was added $65 \mathrm{~mL}$ of dimethylaluminum chloride (65 $\mathrm{mmol}$ of $1 \mathrm{M}$ hexanes solution). The suspension was added a solution of 5 in $5 \mathrm{~mL}$ of $\mathrm{CH}_{2} \mathrm{Cl}_{2}$ via cannula. The reaction mixture was suspension was added a solution of 5 in $5 \mathrm{~mL}$ of $\mathrm{CH}_{2} \mathrm{Cl}_{2}$ via cannula. The reaction mixture was maintained at ambient temperature overnight whereupon $36 \mathrm{~mL}\left(3 \mathrm{~mL} / \mathrm{mmol} \mathrm{Me}_{2} \mathrm{AlCl}\right)$ of $\mathrm{pH} 8$ phosphate buffer was added. The reaction mixture was filtered through Celite to remove the solid aluminum salts and the layers of the filtrate were separated. The aqueous portion was extracted with $\mathrm{CH}_{2} \mathrm{Cl}_{2}(3 \times 100 \mathrm{~mL})$ and the combined organics were dried over $\mathrm{Na}_{2} \mathrm{SO}_{4}$, filtered, and concentrated. The crude oil was purified by silica gel chromatography $\left(\mathrm{Et}_{2} \mathrm{O}\right)$ to provide $3.8 \mathrm{~g}(81 \%)$ of the $\beta$-hydroxyl amide as a pale yellow oil: $[\alpha]_{\mathrm{D}}=-58\left(\right.$ c 3.0, $\left.\mathrm{CHCl}_{3}\right)$; IR (thin film): $3448,3008,2974$, 2938, 1642, 1420, 1389, 1216, 1002, $754 \mathrm{~cm}^{-1}$; ${ }^{1} \mathrm{H}$ NMR (300 MHz, $\left.\mathrm{CDCl}_{3}\right): \delta 4.21$ (ddq, $J=2.6,6.3$, $9.0 \mathrm{~Hz}, 1 \mathrm{H}), 3.70(\mathrm{~s}, 3 \mathrm{H}), 3.20$ (s, 3H), 2.67 (d, $J=16.7 \mathrm{~Hz}, 1 \mathrm{H}), 2.44(\mathrm{dd}, J=9.5,16.8 \mathrm{~Hz}, 1 \mathrm{H}), 1.24$ $(\mathrm{d}, J=6.3 \mathrm{~Hz}, 3 \mathrm{H}) ;{ }^{13} \mathrm{C} \mathrm{NMR}\left(75 \mathrm{MHz}, \mathrm{CDCl}_{3}\right): \delta 173.6,64.0,61.2,39.7,31.7,22.2$; HRMS calcd for $\mathrm{C}_{6} \mathrm{H}_{13} \mathrm{NO}_{3}: 147.0895$, found 147.0895 .

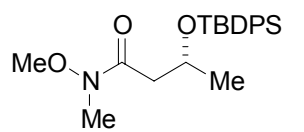

(3R)-3-(tert-Butyldiphenylsilyloxy)- $N$-methoxy- $N$-methylbutyramide (6): To a $0{ }^{\circ} \mathrm{C}$ solution of $0.730 \mathrm{~g}$ of the $\beta$-hydroxyl amide $(4.96 \mathrm{mmol})$ in $8 \mathrm{~mL}$ of $\mathrm{CH}_{2} \mathrm{Cl}_{2}$ was added $1.73 \mathrm{~mL}$ of ${ }^{i} \operatorname{Pr}_{2} \mathrm{NEt}(9.93 \mathrm{mmol}), 1.42 \mathrm{~mL}$ of TBDPSCl (5.46 mmol), and

$0.607 \mathrm{~g}$ of DMAP $(4.96 \mathrm{mmol})$. The resulting solution was warmed to ambient temperature and maintained for $18 \mathrm{~h}$. Saturated aqueous $\mathrm{NaHCO}_{3}(20 \mathrm{~mL})$ was added and the mixture was extracted with $\mathrm{CH}_{2} \mathrm{Cl}_{2}(3 \times 20 \mathrm{~mL})$. The combined organics were washed with $1 \mathrm{M} \mathrm{HCl}(50 \mathrm{~mL})$ and brine $(50$ $\mathrm{mL}$ ), dried over $\mathrm{Na}_{2} \mathrm{SO}_{4}$, filtered, and concentrated. The crude product was purified by flash chromatography on silica gel (15\% EtOAc/hexanes) to afford $1.8 \mathrm{~g}(94 \%)$ of $\mathbf{6}$ as a pale yellow oil. $[\alpha]_{\mathrm{D}}=-9.1$ (c 3.8, $\mathrm{CHCl}_{3}$ ); IR (thin film): 3069, 3045, 2964, 2930, 2856, 1660, 1472, 1385, 1178, $1002,940 \mathrm{~cm}^{-1} ;{ }^{1} \mathrm{H}$ NMR $\left(300 \mathrm{MHz}, \mathrm{CDCl}_{3}\right): \delta 7.71-7.79(\mathrm{~m}, 4 \mathrm{H}), 7.36-7.46(\mathrm{~m}, 6 \mathrm{H}), 4.45$ (sextet, $J=$ $6.0 \mathrm{~Hz}, 1 \mathrm{H}), 3.61(\mathrm{~s}, 3 \mathrm{H}), 3.14(\mathrm{~s}, 3 \mathrm{H}), 2.84$ (dd, $J=6.0,15.0 \mathrm{~Hz}, 1 \mathrm{H}), 2.44$ (dd, $J=6.0,15.0 \mathrm{~Hz}, 1 \mathrm{H})$, $1.16(\mathrm{~d}, J=6.0 \mathrm{~Hz}, 3 \mathrm{H}), 1.07(\mathrm{~s}, 9 \mathrm{H}) ;{ }^{13} \mathrm{C} \mathrm{NMR}\left(75 \mathrm{MHz}, \mathrm{CDCl}_{3}\right): \delta 171.9,135.8,135.7,134.5,134.0$, 129.5, 129.4, 127.4, 127.3, 66.9, 61.1, 41.8, 31.4, 26.9, 23.7, 19.1; HRMS calcd for $\mathrm{C}_{22} \mathrm{H}_{30} \mathrm{NO}_{3} \mathrm{Si}$ : 384.1995, found 384.1976.

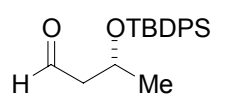

(3R)-3-(tert-Butyldiphenylsilyloxy)butyraldehyde: To a $-78{ }^{\circ} \mathrm{C}$ solution of $0.700 \mathrm{~g}$ of $6(1.82 \mathrm{mmol})$ in $11 \mathrm{~mL}$ of $\mathrm{Et}_{2} \mathrm{O}$ was added $2 \mathrm{~mL}$ of a $1.0 \mathrm{M}$ hexanes solution of ${ }^{i} \mathrm{Bu}_{2} \mathrm{AlH}(2.00 \mathrm{mmol})$ dropwise. The resulting colorless solution was maintained at $-78{ }^{\circ} \mathrm{C}$ for $30 \mathrm{~min}$ whereupon a $1 \mathrm{M} \mathrm{HCl}$ solution $(20 \mathrm{~mL})$ was added and the resulting mixture was extracted with $\mathrm{Et}_{2} \mathrm{O}(3 \times 20 \mathrm{~mL})$. The combined organics were washed with brine $(30 \mathrm{~mL})$ and filtered through Celite. The filtrate was then dried over $\mathrm{Na}_{2} \mathrm{SO}_{4}$, filtered, and concentrated. Purification of the crude oil by flash chromatography (5\% EtOAc/hexanes) afforded $0.569 \mathrm{~g}(95 \%)$ of the title aldehyde as a clear, colorless liquid. $[\alpha]_{\mathrm{D}}=+7.5\left(c\right.$ 2.9, $\left.\mathrm{CHCl}_{3}\right)$; IR (thin film) 3069, 3048, 2961, 2930, 2893, 2859, 2720, 1728, 1425, 1379, 1110, $823 \mathrm{~cm}^{-1} ;{ }^{1} \mathrm{H}$ NMR $\left(300 \mathrm{MHz}, \mathrm{CDCl}_{3}\right): \delta 9.78(\mathrm{t}, J=2.6 \mathrm{~Hz}, 1 \mathrm{H})$, 7.69-7.75 (m, 4H), 7.38-7.49 (m, 6H), 4.38 (sextet, $J=6.0 \mathrm{~Hz}, 1 \mathrm{H}), 2.57$ (ddd, $J=2.9,6.0,15.8 \mathrm{~Hz}$, $1 \mathrm{H}), 2.49$ (ddd, $J=2.2,5.6,15.8 \mathrm{~Hz}, 1 \mathrm{H}), 1.21(\mathrm{~d}, J=6.0 \mathrm{~Hz}, 3 \mathrm{H}), 1.08(\mathrm{~s}, 9 \mathrm{H}) ;{ }^{13} \mathrm{C}$ NMR $(75 \mathrm{MHz}$, 
$\left.\mathrm{CDCl}_{3}\right): \delta 202.1,136.1,134.4,134.0,130.2,130.0,128.0,127.9,66.0,53.1,27.2,24.1,19.5 ; \mathrm{HRMS}$ calcd for $\mathrm{C}_{16} \mathrm{H}_{17} \mathrm{O}_{2} \mathrm{Si}$ : 269.0998, found 269.0999.

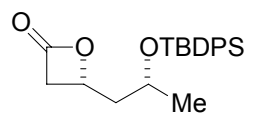

(4R, 2'R)-4-[2-tert-Butyldiphenylsilyloxy)propyl]oxetan-2-one (7): To a $-50{ }^{\circ} \mathrm{C}$ solution of $0.870 \mathrm{~g}$ of aluminum complex $4(1.50 \mathrm{mmol})$ in $25 \mathrm{~mL}$ of $\mathrm{CH}_{2} \mathrm{Cl}_{2}$ was added $4.43 \mathrm{~mL}$ of ${ }^{i} \operatorname{Pr}_{2} \mathrm{NEt}(25.4 \mathrm{mmol})$ followed by $2.10 \mathrm{~mL}$ of acetyl bromide (28.4 $\mathrm{mmol}$ ). To the resulting yellow solution was added a solution of $4.88 \mathrm{~g}$ of aldehyde (prepared above; $15.0 \mathrm{mmol}$ ) in $5 \mathrm{~mL}$ of $\mathrm{CH}_{2} \mathrm{Cl}_{2}$. The reaction was maintained at $-50{ }^{\circ} \mathrm{C} 12 \mathrm{~h}$ and was then quenched by pouring into ice-cold hexanes $(150 \mathrm{~mL})$. The resulting mixture was filtered through silica gel $(50 \%$ EtOAc/Hex) and concentrated. The crude product was then purified by flash chromatography $(3 \%$ EtOAc/hexanes) to afford $4.77 \mathrm{~g}(86 \%)$ of 7 as a white solid. $[\alpha]_{\mathrm{D}}=+17\left(c 2.6, \mathrm{CHCl}_{3}\right)$; IR (thin film): 3072, 3051, 2964, 2930, 2893, 2859, 1824, 1425, 1376, 1110, $909 \mathrm{~cm}^{-1} ;{ }^{1} \mathrm{H}$ NMR $(300 \mathrm{MHz}$, $\mathrm{CDCl}_{3}$ ): $\delta$ 7.66-7.70 (m, 4H), 7.38-7.45 (m, 6H), 4.69 (dq, $\left.J=4.4,6.7 \mathrm{~Hz}, 1 \mathrm{H}\right), 4.04$ (dddd, $J=6.1$, $6.1,6.1,12.1 \mathrm{~Hz}, 1 \mathrm{H}), 3.29(\mathrm{dd}, J=5.8,16.3 \mathrm{~Hz}, 1 \mathrm{H}), 2.95$ (dd, $J=4.3,16.3 \mathrm{~Hz}, 1 \mathrm{H}), 2.13$ (ddd, $J=$ 6.3, 6.3, $14.0 \mathrm{~Hz}, 1 \mathrm{H}), 1.81(\mathrm{ddd}, J=5.0,7.0,14.0 \mathrm{~Hz}, 1 \mathrm{H}), 1.19(\mathrm{~d}, J=6.2 \mathrm{~Hz}, 3 \mathrm{H}), 1.09(\mathrm{~s}, 9 \mathrm{H}) ;{ }^{13} \mathrm{C}$ NMR (75 MHz, $\left.\mathrm{CDCl}_{3}\right): \delta 168.4,136.2,136.1,134.3,134.0,130.2,130.1,128.1,127.9,68.8,66.7$, 44.0, 43.6, 27.3, 23.6, 19.5; HRMS calcd for $\mathrm{C}_{18} \mathrm{H}_{19} \mathrm{O}_{3} \mathrm{Si}$ : 311.1103, found 311.1107.

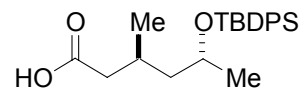

$(3 S, 5 R)$-5-(tert-Butyldiphenylsilyloxy)-3-methylhexanoic acid (8): To a $-50{ }^{\circ} \mathrm{C}$ solution of $2.69 \mathrm{~g}$ of $\mathrm{CuBr}(18.8 \mathrm{mmol})$ in $185 \mathrm{~mL}$ of THF and $20 \mathrm{~mL}$ of dimethylsulfide was slowly added $12.5 \mathrm{~mL}$ of a $3.0 \mathrm{M}$ ethereal solution of methylmagnesium bromide $(37.5 \mathrm{mmol})$ dropwise. The resulting pale green solution was stirred at $-50^{\circ} \mathrm{C}$ for $30 \mathrm{~min}$ then warmed to $-30{ }^{\circ} \mathrm{C}$ for $30 \mathrm{~min}$. The reaction was then cooled to $-50^{\circ} \mathrm{C}$ and $4.6 \mathrm{~g}$ of $7(12.5 \mathrm{mmol})$ in $15 \mathrm{~mL}$ of THF was added via cannula. After maintaining the reaction at $-50{ }^{\circ} \mathrm{C}$ for $45 \mathrm{~min}, 2.4 \mathrm{~mL}$ of TMSCl $(18.8 \mathrm{mmol})$ was added and the reaction was allowed to warm to $25^{\circ} \mathrm{C}$ overnight. A mixture of saturated $\mathrm{NH}_{4} \mathrm{Cl}(500 \mathrm{~mL})$ and $1 \mathrm{M} \mathrm{HCl}(200 \mathrm{~mL})$ was added and the resulting mixture was extracted with $\mathrm{Et}_{2} \mathrm{O}(4 \times 150 \mathrm{~mL})$. The combined organics were washed with saturated $\mathrm{NH}_{4} \mathrm{Cl}$ and brine $(50 \mathrm{~mL})$, dried over $\mathrm{Na}_{2} \mathrm{SO}_{4}$, filtered, and concentrated. The crude product was purified by flash chromatography $\left(10 \%\right.$ EtOAc/hexanes) to afford $3.85 \mathrm{~g}(80 \%)$ of $\mathbf{8}$ as a viscous pale yellow oil. $[\alpha]_{\mathrm{D}}=$ +6.7 (c 2.2, $\mathrm{CHCl}_{3}$ ); IR (thin film): 3070, 3045, 2961, 2928, 2853, 1704, 1426, 1373, 1108, 909, 820 $\mathrm{cm}^{-1} ;{ }^{1} \mathrm{H}$ NMR $\left(300 \mathrm{MHz}, \mathrm{CDCl}_{3}\right): \delta$ 7.77-7.82 (m, 4H), 7.41-7.52 (m, 6H), 3.92-4.02 (m, 1H), 2.20$2.32(\mathrm{~m}, 2 \mathrm{H}), 2.06-2.15(\mathrm{~m}, 1 \mathrm{H}), 1.69(\mathrm{ddd}, J=5.1,7.5,13.3 \mathrm{~Hz}, 1 \mathrm{H}), 1.32(\mathrm{ddd}, J=4.6,7.7,12.9 \mathrm{~Hz}$, $1 \mathrm{H}), 1.15-1.18(\mathrm{~m}, 12 \mathrm{H}), 0.91(\mathrm{~d}, J=6.4 \mathrm{~Hz}, 3 \mathrm{H}) ;{ }^{13} \mathrm{C}$ NMR $\left(75 \mathrm{MHz}, \mathrm{CDCl}_{3}\right): \delta 179.6,135.9,134.8$, 134.2, 129.6, 129.4, 127.5, 127.4, 67.5, 46.7, 41.9, 27.0, 26.7, 24.0, 19.7, 19.3; HRMS calcd for $\mathrm{C}_{19} \mathrm{H}_{23} \mathrm{O}_{3} \mathrm{Si}: 327.1416$, found 327.1419 .

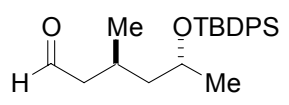

(3S, 5R)-5-(tert-Butyldiphenylsilyloxy)-3-methylhexanal (9): To a $25^{\circ} \mathrm{C}$ solution of $3.75 \mathrm{~g}$ of carboxylic acid $\mathbf{8}(9.76 \mathrm{mmol})$ in $50 \mathrm{~mL}$ of $\mathrm{Et}_{2} \mathrm{O}$ was slowly added 7.3 $\mathrm{mL}$ of a $2.0 \mathrm{M}$ THF solution of $\mathrm{H}_{3} \mathrm{~B} \cdot \mathrm{SMe}_{2}(14.6 \mathrm{mmol})$ dropwise. The resulting clear, colorless solution was heated to reflux and maintained $1 \mathrm{~h}$. After cooling to $25^{\circ} \mathrm{C}$, the solvent was evaporated and the remaining viscous residue was dissolved in $50 \mathrm{~mL}$ of $\mathrm{CH}_{2} \mathrm{Cl}_{2}$. To this colorless solution was added $5.26 \mathrm{~g}$ of pyridinium chlorochromate $(24.4 \mathrm{mmol})$ and the resulting brown suspension was heated to reflux and maintained for $2.5 \mathrm{~h}$. The reaction was then cooled to $25^{\circ} \mathrm{C}$, diluted with $\mathrm{Et}_{2} \mathrm{O}$, filtered through Celite, and concentrated. The crude product was purified by flash chromatography (5\% EtOAc/hexanes) to afford $3.05 \mathrm{~g}(85 \%)$ of 9 as a pale yellow oil: $[\alpha]_{\mathrm{D}}=-1.0\left(\mathrm{c} 2.6, \mathrm{CHCl}_{3}\right)$; IR (thin film): $3067,3048,2959,2928,2853,2708,1726,1426,1373,1111,1067,823 \mathrm{~cm}^{-1} ;{ }^{1} \mathrm{H}$ NMR 
$\left(300 \mathrm{MHz}, \mathrm{CDCl}_{3}\right): \delta 9.63(\mathrm{t}, J=2.5 \mathrm{~Hz}, 1 \mathrm{H}), 7.67-7.72(\mathrm{~m}, 4 \mathrm{H}), 7.36-7.44(\mathrm{~m}, 6 \mathrm{H}), 3.81-3.91(\mathrm{~m}$, $1 \mathrm{H}), 2.07-2.23(\mathrm{~m}, 2 \mathrm{H}), 1.55(\mathrm{ddd}, J=5.0,7.7,13.0 \mathrm{~Hz}, 1 \mathrm{H}), 1.23(\mathrm{ddd}, J=4.7,8.2,13.4 \mathrm{~Hz}, 1 \mathrm{H})$, $1.09(\mathrm{~d}, J=6.0 \mathrm{~Hz}, 3 \mathrm{H}), 1.06(\mathrm{~s}, 9 \mathrm{H}), 0.78(\mathrm{~d}, J=6.4 \mathrm{~Hz}, 3 \mathrm{H}) ;{ }^{13} \mathrm{C} \mathrm{NMR}\left(75 \mathrm{MHz}, \mathrm{CDCl}_{3}\right): \delta 202.6$, $135.9,134.7,134.2,129.6,129.5,127.6,127.4,67.5,51.3,47.1,27.1,24.9,24.0,20.0,19.3$.

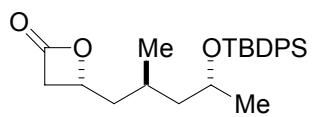

(4R, 2'S, 4'R)-4-[4'-(tert-Butyldiphenylsilyloxy)-2-methylpentyl]oxetan-2-one (10): To a $-50{ }^{\circ} \mathrm{C}$ solution of $0.704 \mathrm{~g}$ of aluminum triamine catalyst 4 (1.21 $\mathrm{mmol})$ in $16 \mathrm{~mL}$ of $\mathrm{CH}_{2} \mathrm{Cl}_{2}$ was added $2.40 \mathrm{~mL}$ of $i \mathrm{Pr}_{2} \mathrm{NEt}(13.7 \mathrm{mmol})$ followed by $1.13 \mathrm{~mL}$ of acetyl bromide $(15.3 \mathrm{mmol})$. The resulting yellow solution was stirred at $-50{ }^{\circ} \mathrm{C}$ whereupon $2.97 \mathrm{~g}$ of aldehyde $9(8.07 \mathrm{mmol})$ in $5 \mathrm{~mL}$ of $\mathrm{CH}_{2} \mathrm{Cl}_{2}$ was added slowly dropwise via syringe. The reaction was maintained at $-50{ }^{\circ} \mathrm{C}$ for $16 \mathrm{~h}$, whereupon the reaction was quenched by pouring into ice-cold hexanes $(100 \mathrm{~mL})$. The resulting mixture was filtered through silica gel $(50 \%$ EtOAc/Hex eluant) and the filtrate concentrated. The crude product mixture was purified by flash chromatography $\left(11 \%\right.$ hexanes/benzene) to afford $2.76 \mathrm{~g}(84 \%)$ of $\mathbf{1 0}$ as a white solid: $[\alpha]_{\mathrm{D}}=+21(c$ 2.3, $\mathrm{CHCl}_{3}$ ); IR (thin film): 3070, 3048, 2965, 2931, 2853, 1828, 1426, 1376, 1200, 1111, 1061, 820 $\mathrm{cm}^{-1} ;{ }^{1} \mathrm{H}$ NMR $\left(300 \mathrm{MHz}, \mathrm{CDCl}_{3}\right): \delta$ 7.66-7.72 (m, 4H), 7.35-7.47 (m, 6H), $4.45(\mathrm{dtd}, J=4.5,5.6,8.0$ $\mathrm{Hz}, 1 \mathrm{H}), 3.80-3.90$ (m, 1H), 3.45 (dd, $J=5.7,16.2 \mathrm{~Hz}, 1 \mathrm{H}), 2.95$ (dd, $J=4.3,16.2 \mathrm{~Hz}, 1 \mathrm{H}), 1.73-1.84$ $(\mathrm{m}, 1 \mathrm{H}), 1.67(\mathrm{ddd}, J=5.2,7.8,13.7 \mathrm{~Hz}, 1 \mathrm{H}), 1.54(\mathrm{ddd}, J=5.2,7.6,13.4 \mathrm{~Hz}, 1 \mathrm{H}), 1.37(\mathrm{ddd}, J=5.3$, 7.9, $13.6 \mathrm{~Hz}, 1 \mathrm{H}), 1.20$ (ddd, $J=4.9,8.2,12.7 \mathrm{~Hz}, 1 \mathrm{H}), 1.10(\mathrm{~d}, J=6.0 \mathrm{~Hz}, 3 \mathrm{H}), 1.05$ (s, 9H), $0.76(\mathrm{~d}$, $J=6.5 \mathrm{~Hz}, 3 \mathrm{H}) ;{ }^{13} \mathrm{C} \mathrm{NMR}\left(75 \mathrm{MHz}, \mathrm{CDCl}_{3}\right): \delta 168.2,135.9,134.7,134.3,129.6,129.5,127.6,127.4$, 69.7, 67.4, 47.2, 43.4, 42.2, 27.0, 26.7, 24.1, 19.6, 19.3; HRMS calcd for $\mathrm{C}_{21} \mathrm{H}_{25} \mathrm{O}_{3} \mathrm{Si}$ : 353.1572, found 353.1559 .

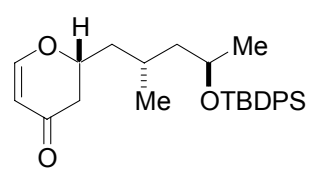

(2R, 2'S, $\left.\quad 4^{\prime} R\right)$-2-[4-(tert-Butyldiphenylsilyloxy)-2-methylpentyl]-2,3dihydropyran-4-one (11): To a $0{ }^{\circ} \mathrm{C}$ solution of $0.690 \mathrm{~mL}$ of diisopropylamine (4.93 mmol) in $20 \mathrm{~mL}$ of THF was added $2.95 \mathrm{~mL}$ of a $1.6 \mathrm{M}$ solution of ${ }^{n} \mathrm{BuLi}$ in hexanes $(4.68 \mathrm{mmol})$ slowly dropwise. The resulting solution was maintained at $0{ }^{\circ} \mathrm{C}$ for $30 \mathrm{~min}$ whereupon $0.590 \mathrm{~mL}$ of acetaldehyde $N$-piperidine hydrazone $(4.93 \mathrm{mmol})$ was added. The resulting heterogeneous mixture was stirred at $0{ }^{\circ} \mathrm{C}$ for $1 \mathrm{~h}$ then cooled to $-78{ }^{\circ} \mathrm{C}$ whereupon 1.01 $\mathrm{g}$ of $10(2.46 \mathrm{mmol})$ in $2 \mathrm{~mL}$ of THF was added via cannula. The resulting yellow solution was maintained at $-78{ }^{\circ} \mathrm{C}$ overnight. The reaction was quenched with saturated $\mathrm{NaHCO}_{3}$ and extracted with EtOAc $(3 \times 20 \mathrm{~mL})$. The combined organics were washed with brine, dried over $\mathrm{Na}_{2} \mathrm{SO}_{4}$, filtered, and concentrated. The remaining residue was dissolved in THF and treated with $2.8 \mathrm{~g}$ of camphorsulfonic acid $(12.1 \mathrm{mmol})$ and the reaction was warmed to $60{ }^{\circ} \mathrm{C}$ over the course of $1 \mathrm{~h}$ and then allowed to cool to ambient temperature. The reaction was quenched with saturated $\mathrm{NaHCO}_{3}$ and extracted with EtOAc. The combined organics were washed with brine, dried over $\mathrm{Na}_{2} \mathrm{SO}_{4}$, filtered, and concentrated. Purifying the crude product mixture by flash chromatography ( $8 \%$ EtOAc/hexanes) afforded $0.665 \mathrm{~g}(62 \%)$ of 11 as a yellow oil. $[\alpha]_{\mathrm{D}}=+68\left(c 2.1, \mathrm{CHCl}_{3}\right)$; IR (thin film): 3073, 3051, 2962, 2931, 2860, 1673, 1593, 1429, 1274, $1114,909 \mathrm{~cm}^{-1} ;{ }^{1} \mathrm{H}$ NMR $\left(300 \mathrm{MHz}, \mathrm{CDCl}_{3}\right): \delta 7.68-7.73$ $(\mathrm{m}, 4 \mathrm{H}), 7.35-7.47(\mathrm{~m}, 6 \mathrm{H}), 7.29(\mathrm{~d}, J=6.0 \mathrm{~Hz}, 1 \mathrm{H}), 5.39(\mathrm{dd}, J=1.0,6.0 \mathrm{~Hz}, 1 \mathrm{H}), 4.40$ (dddd, $J=$ 4.0, 4.0, 8.3, $13.2 \mathrm{~Hz}, 1 \mathrm{H}), 3.84-3.94(\mathrm{~m}, 1 \mathrm{H}), 2.43(\mathrm{dd}, J=12.5,16.8 \mathrm{~Hz}, 2 \mathrm{H}), 1.81-1.97(\mathrm{~m}, 1 \mathrm{H})$, 1.67 (ddd, $J=4.5,9.5,14.2 \mathrm{~Hz}, 1 \mathrm{H}), 1.52(\mathrm{ddd}, J=5.7,7.3,13.4 \mathrm{~Hz}, 1 \mathrm{H}), 1.12(\mathrm{~d}, J=6.0 \mathrm{~Hz}, 3 \mathrm{H})$, $1.06(\mathrm{~s}, 9 \mathrm{H}), 0.76(\mathrm{~d}, J=6.6 \mathrm{~Hz}, 3 \mathrm{H}) ;{ }^{13} \mathrm{C} \mathrm{NMR}\left(75 \mathrm{MHz}, \mathrm{CDCl}_{3}\right): \delta 192.5,163.0,135.9,134.7,134.3$, $129.5,129.4,127.5,127.4,106.9,67.5,47.6$, 47.1, 42.4, 41.9, 27.0, 25.3, 24.0, 19.4, 19.2; HRMS calcd for $\mathrm{C}_{23} \mathrm{H}_{27} \mathrm{O}_{3} \mathrm{Si}: 379.1729$, found 379.1729 . 


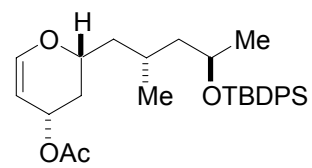

$(2 R, \quad 2 ' S, \quad 4 ' R, \quad 4 S)-2-[4-(t e r t-B u t y l d i p h e n y l s i l y l o x y)-2-m e t h y l p e n t y l]-3,4-$ dihydro-2 $\mathrm{H}$-pyran-4-yl-acetate: To a $0{ }^{\circ} \mathrm{C}$ solution of $0.408 \mathrm{~g}$ of $\mathbf{1 1}(0.936$ $\mathrm{mmol})$ and $0.418 \mathrm{~g}$ of $\mathrm{CeCl}_{3} \cdot 7 \mathrm{H}_{2} \mathrm{O}(1.12 \mathrm{mmol})$ in $10 \mathrm{~mL}$ of $\mathrm{MeOH}$ was added $0.039 \mathrm{~g}$ of $\mathrm{NaBH}_{4}(1.03 \mathrm{mmol})$ portionwise. After stirring $40 \mathrm{~min}$ at $0{ }^{\circ} \mathrm{C}$, the reaction was quenched by adding $10 \mathrm{~mL}$ of water. The mixture was extracted with $\mathrm{CH}_{2} \mathrm{Cl}_{2}(4 \times 20 \mathrm{~mL})$ and the combined organics were dried over $\mathrm{Na}_{2} \mathrm{SO}_{4}$, filtered, and concentrated to afford the corresponding allylic alcohol. The crude alcohol $(0.410 \mathrm{~g}, 0.936 \mathrm{mmol})$ was dissolved in $8 \mathrm{~mL}$ of $\mathrm{CH}_{2} \mathrm{Cl}_{2}$ and cooled to $0{ }^{\circ} \mathrm{C}$. To this solution was added $0.391 \mathrm{~mL}$ of $\mathrm{Et}_{3} \mathrm{~N}(2.81 \mathrm{mmol}), 0.011 \mathrm{~g}$ of DMAP $(0.0936 \mathrm{mmol})$, and $0.135 \mathrm{~mL}$ of acetic anhydride $(1.40 \mathrm{mmol})$. The resulting clear, colorless solution was maintained at ambient temperature for $2 \mathrm{~h}$ whereupon the reaction mixture was concentrated and purified by flash chromatography (hexanes/ $\mathrm{Et}_{3} \mathrm{~N} 50: 1$ ) to afford $0.404 \mathrm{~g} \mathrm{(90 \% )} \mathrm{of} \mathrm{the}$ allylic acetate as a clear colorless oil. $[\alpha]_{\mathrm{D}}=+17\left(\right.$ c 2.0, $\left.\mathrm{CHCl}_{3}\right)$; IR (thin film): 3070, 3048, 2961, 2931, 2856, 1729, 1645, 1429, 1370, 1231, 1108, 1040, $912 \mathrm{~cm}^{-1} ;{ }^{1} \mathrm{H}$ NMR $\left(300 \mathrm{MHz}, \mathrm{CDCl}_{3}\right): \delta$ 7.68$7.73(\mathrm{~m}, 4 \mathrm{H}), 7.35-7.43(\mathrm{~m}, 6 \mathrm{H}), 6.41(\mathrm{~d}, J=6.2 \mathrm{~Hz}, 1 \mathrm{H}), 5.38(\mathrm{tq} J=1.5,6.6 \mathrm{~Hz}, 1 \mathrm{H}), 4.72(\mathrm{ddd}, J=$ 2.2, 3.8, 6.2 Hz, 1H), 3.95-4.03 (m, 1H), 3.83-3.94 (m, 1H), 2.10-2.16 (m, 1H), $2.05(\mathrm{~s}, 3 \mathrm{H}), 1.78-1.95$ $(\mathrm{m}, 1 \mathrm{H}), 1.57-1.69(\mathrm{~m}, 1 \mathrm{H}), 1.47-1.56(\mathrm{~m}, 1 \mathrm{H}), 1.19(\mathrm{ddd}, J=5.3,8.0,13.5 \mathrm{~Hz}, 1 \mathrm{H}), 1.06-1.10(\mathrm{~m}$, $12 \mathrm{H}), 0.75(\mathrm{~d}, J=6.5 \mathrm{~Hz}, 3 \mathrm{H}) ;{ }^{13} \mathrm{C}$ NMR $\left(75 \mathrm{MHz}, \mathrm{CDCl}_{3}\right): \delta 171.8,146.7,135.9,134.9,134.4$, $129.5,129.4,127.5,127.3,100.8,72.2$, 67.6, 65.7, 47.7, 42.2, 34.0, 27.0, 25.5, 24.0, 21.2, 19.5, 19.2; EI-MS e/v $423\left(\mathrm{M}^{+}-{ }^{t} \mathrm{Bu}\right), 363\left(\mathrm{M}^{+}{ }^{t} \mathrm{Bu}-\mathrm{AcOH}\right), 253,199,147$; HRMS calcd for $\mathrm{C}_{23} \mathrm{H}_{27} \mathrm{O}_{2} \mathrm{Si}$ : 363.1780 , found 363.1765 .

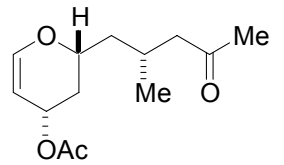

(2R, 4S, 2'S)-(2-methyl-4-oxopentyl)-3,4-dihydro-2H-pyran-4-yl-acetate (13): To a $0{ }^{\circ} \mathrm{C}$ solution of $0.400 \mathrm{~g}$ of the allylic acetate (prepared above; $0.833 \mathrm{mmol}$ ) in 0.25 $\mathrm{mL}$ of THF was slowly added $1.95 \mathrm{~mL}$ of a $1.0 \mathrm{M}$ THF solution of tetrabutylammonium fluoride $(1.95 \mathrm{mmol})$ dropwise. The reaction was warmed to ambient temperature and maintained for $6 \mathrm{~h}$ then diluted with EtOAc $(100 \mathrm{~mL})$. The resulting solution was washed with brine, dried over $\mathrm{Na}_{2} \mathrm{SO}_{4}$, filtered, and concentrated. The crude alcohol was dissolved in $6 \mathrm{~mL}$ of $\mathrm{CH}_{2} \mathrm{Cl}_{2}$ and $1.0 \mathrm{~g}$ of $4 \AA$ molecular sieves was added followed by $0.784 \mathrm{~g}$ of pyridinium dichromate $(2.08 \mathrm{mmol})$. The resulting brown suspension was maintained at ambient temperature for $1.5 \mathrm{~h}$ before being diluted with $\mathrm{Et}_{2} \mathrm{O}(100 \mathrm{~mL})$ and filtered through Celite. The filtrate was concentrated and the crude product mixture was purified by flash chromatography(hexanes/ $/ \mathrm{t}_{3} \mathrm{~N}$ $50: 1)$ to afford $0.160 \mathrm{~g}(80 \%)$ of $\mathbf{1 3}$ as a colorless oil. $[\alpha]_{\mathrm{D}}=+9.8\left(\mathrm{c} 2.5, \mathrm{CHCl}_{3}\right)$; IR (thin film): 3067, 2960, 2930, 1729, 1644, 1372, 1232, 1042, 1023, $805 \mathrm{~cm}^{-1} ;{ }^{1} \mathrm{H}$ NMR $\left(300 \mathrm{MHz}, \mathrm{CDCl}_{3}\right): \delta 6.40(\mathrm{~d}, J=$ $6.2 \mathrm{~Hz}, 1 \mathrm{H}), 5.33-5.38(\mathrm{~m}, 1 \mathrm{H}), 4.69-4.72(\mathrm{~m}, 1 \mathrm{H}), 3.97-4.05(\mathrm{~m}, 1 \mathrm{H}), 2.22-2.50(\mathrm{~m}, 3 \mathrm{H}), 2.13-2.20$ $(\mathrm{m}, 1 \mathrm{H}), 2.10(\mathrm{~s}, 3 \mathrm{H}), 2.02(\mathrm{~s}, 3 \mathrm{H}), 1.61-1.73(\mathrm{~m}, 2 \mathrm{H}), 1.27(\mathrm{ddd}, J=3.3,8.4,14.0 \mathrm{~Hz}, 1 \mathrm{H}), 0.92(\mathrm{~d}, J$ $=6.1 \mathrm{~Hz}, 3 \mathrm{H}) ;{ }^{13} \mathrm{C}$ NMR $\left(75 \mathrm{MHz}, \mathrm{CDCl}_{3}\right): \delta 208.1,170.7,146.4,100.9,72.2,65.5,51.4,41.7,34.0$, $30.2,25.7,21.1,19.6$.

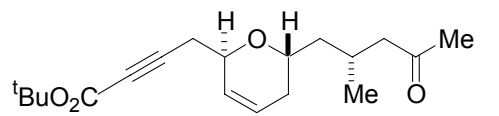

$(2 R, 6 R, 2 ' S)-4-[6-(2-M e t h y l-4-0 x o p e n t y l)-5,6-d i h y d r o-2 H$-pyran-2yl]but-2-ynoic acid, tert-butyl ester (2): To a $-78{ }^{\circ} \mathrm{C}$ solution of 0.064 $\mathrm{g}$ of $13(0.267 \mathrm{mmol})$ in $1 \mathrm{~mL}$ of $\mathrm{CH}_{2} \mathrm{Cl}_{2}$ was slowly added $0.457 \mathrm{~g}$ of 14 (1.07 mmol) in $0.5 \mathrm{~mL}$ of $\mathrm{CH}_{2} \mathrm{Cl}_{2}$. To the resulting solution was added a solution of $0.129 \mathrm{~g}$ of tributyltin trifluoromethanesulfonate $(0.293 \mathrm{mmol})$ in $1 \mathrm{~mL}$ of $\mathrm{CH}_{2} \mathrm{Cl}_{2}$ via cannula. The reaction was maintained at $-78{ }^{\circ} \mathrm{C}$ for $2 \mathrm{~h}$ then allowed to slowly warm to ambient temperature. Saturated aqueous $\mathrm{NaHCO}_{3}(5 \mathrm{~mL})$ was added and the mixture was extracted with $\mathrm{CH}_{2} \mathrm{Cl}_{2}(4 \times 6 \mathrm{~mL})$. The combined organics were washed with brine, dried over $\mathrm{Na}_{2} \mathrm{SO}_{4}$, filtered, and concentrated. The crude product 
mixture was purified by flash chromatography ( $2 \%$ EtOAc/hexanes) to afford $0.068 \mathrm{~g}(80 \%)$ of $\mathbf{2}$ as a clear colorless oil. $[\alpha]_{\mathrm{D}}=-72$ (c 1.5, $\mathrm{CHCl}_{3}$ ); IR (thin film): 3039, 2980, 2931, 2241, 1706, 1369, 1282, 1160, 1074, 912, $732 \mathrm{~cm}^{-1} ;{ }^{1} \mathrm{H}$ NMR $\left(300 \mathrm{MHz}, \mathrm{CDCl}_{3}\right): \delta 5.85-5.92(\mathrm{~m}, 1 \mathrm{H}), 5.74-5.79(\mathrm{~m}$, $1 \mathrm{H}$ ), 4.34-4.46 (m, 1H), 3.74 (dddd, $J=3.6,8.5,8.5,12.5 \mathrm{~Hz}, 1 \mathrm{H}$ ), 2.61 (dd, $J=7.0,16.9 \mathrm{~Hz}, 1 \mathrm{H}$ ), $2.50(\mathrm{dd}, J=6.9,17.0 \mathrm{~Hz}, 1 \mathrm{H}), 2.44(\mathrm{dd}, J=6.9,17.0 \mathrm{~Hz}, 1 \mathrm{H}), 2.22-2.33(\mathrm{~m}, 2 \mathrm{H}), 2.11(\mathrm{~s}, 3 \mathrm{H}), 1.82-$ 2.02 (m, 3H), 1.53 (ddd, $J=4.5,9.7,14.0 \mathrm{~Hz}, 1 \mathrm{H}), 1.45$ (s, 9H), 1.22 (ddd, $J=3.1,8.3,12.9 \mathrm{~Hz}, 1 \mathrm{H}$ ), $0.92(\mathrm{~d}, J=6.2 \mathrm{~Hz}, 3 \mathrm{H}) ;{ }^{13} \mathrm{C}$ NMR $\left(75 \mathrm{MHz}, \mathrm{CDCl}_{3}\right): \delta 208.6,152.5,127.4,125.9,83.3,82.9,75.9$, 70.1, 66.1, 51.6, 42.1, 30.8, 30.0, 28.0, 26.0, 24.6, 19.6; EI-MS elv $321\left(\mathrm{M}^{+}+\mathrm{H}\right), 265,181,163,123$, $105,57$.

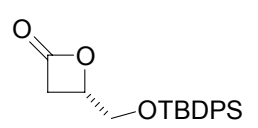

(4S)-(tert-Butyldiphenylsiloxymethyl)-oxetane-2-one $\quad(16):^{2} \quad$ To $\quad$ a $\quad-50 \quad{ }^{\circ} \mathrm{C}$ methylene chloride solution of $58 \mathrm{mg}$ of aluminum triamine catalyst $4(0.10 \mathrm{mmol})$ in $5.7 \mathrm{~mL}$ of $\mathrm{CH}_{2} \mathrm{Cl}_{2}$ was added $0.30 \mathrm{~mL}$ of DIPEA $(1.7 \mathrm{mmol})$ followed by $0.14 \mathrm{~mL}$ of acetylbromide $(1.9 \mathrm{mmol})$. The resulting yellow solution was stirred at $-50{ }^{\circ} \mathrm{C}$ whereupon $0.298 \mathrm{~g}$ of 2-tert-butyldiphenylsiloxyacetaldehyde $(1.0 \mathrm{mmol})$ was added dropwise via syringe. After maintaining at $-50{ }^{\circ} \mathrm{C}$ for $12 \mathrm{~h}$, the reaction mixture was diluted with $10 \mathrm{~mL}$ of pentane, filtered through silica gel $(30 \% \mathrm{EtOAc} / \mathrm{hexanes})$, and concentrated. The resulting residue was purified by silica gel chromatography $(10 \% \mathrm{EtOAc} /$ hexanes) to provide $0.30 \mathrm{~g}$ of $\mathbf{1 6}(92 \%)$ as a white crystalline solid in $92 \%$ ee; HPLC (90/10 hexanes $/ \mathrm{PrOH}, 1.0 \mathrm{~mL} / \mathrm{min}) \mathrm{T}_{\mathrm{r}(\min )}=7.63(R), 13.27(S)$.

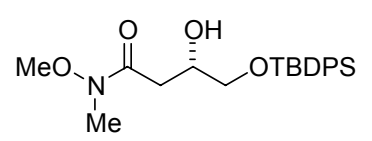

\section{(3S)-4-(tert-Butyldiphenylsilanyloxy)-hydroxy- $\mathrm{N}$ -}

methoxy- $\mathrm{N}$-methylbutyramide: To a $\quad 0 \quad{ }^{\circ} \mathrm{C}$ solution of $1.36 \mathrm{~g}$ of methoxymethylamine hydrochloride $(14 \mathrm{mmol})$ in $30 \mathrm{~mL}$ of $\mathrm{CH}_{2} \mathrm{Cl}_{2}$ was added $14 \mathrm{~mL}$ of a $1 \mathrm{M}$ hexanes solution of dimethylaluminum chloride $(14 \mathrm{mmol})$. The resulting solution was allowed to warm to ambient temperature and maintained for $1 \mathrm{~h}$. To the resulting suspension was added a solution of $2.39 \mathrm{~g}$ of $\mathbf{1 6}(7.0 \mathrm{mmol})$ in $5 \mathrm{~mL}$ of $\mathrm{CH}_{2} \mathrm{Cl}_{2}$ via cannula. The reaction mixture was maintained for $2 \mathrm{~h}$ at ambient temperature, then quenched with $42 \mathrm{~mL}$ of $\mathrm{pH} 8$ hydrogen phosphate buffer. The resulting mixture was filtered through a pad of celite and the biphasic filtrate was separated and the aqueous layer was extracted with $\mathrm{CH}_{2} \mathrm{Cl}_{2}(2 \times 10 \mathrm{~mL})$. The combined organics were dried over $\mathrm{MgSO}_{4}$, filtered, and concentrated. The crude product mixture was purified by silica gel chromatography (30\% EtOAc/hexanes) to provide $2.64 \mathrm{~g}(94 \%)$ of the title $\beta$-hydroxyl amide as a white solid. $[\alpha]_{\mathrm{D}}=-16\left(c 1.1, \mathrm{CHCl}_{3}\right)$; IR (thin film): 3441.6, 3069, 3046, 2954, 2931, 2891, 2855, $1640,1465,1426,1386,1184,1109,998,828,741,705,610 \mathrm{~cm}^{-1} ;{ }^{1} \mathrm{H}$ NMR $\left(300 \mathrm{MHz}, \mathrm{CDCl}_{3}\right)$ : $\delta 7.72(\mathrm{dd}, J=1.8,5.0 \mathrm{~Hz}, 4 \mathrm{H}), 7.44-7.36(\mathrm{~m}, 6 \mathrm{H}), 4.24(\mathrm{~m}, 1 \mathrm{H}), 3.85(\mathrm{~d}, J=3.2 \mathrm{~Hz}, 1 \mathrm{H}), 3.80(\mathrm{dd}, J$ $=4.7,10.1 \mathrm{~Hz}, 1 \mathrm{H}), 3.72(\mathrm{dd}, J=5.0,10.0 \mathrm{~Hz}, 1 \mathrm{H}), 3.64(\mathrm{~s}, 3 \mathrm{H}), 3.16(\mathrm{~s}, 3 \mathrm{H}), 2.78(\mathrm{~d}, J=15.6 \mathrm{~Hz}$, $1 \mathrm{H}), 2.67(\mathrm{dd}, J=8.3,15.2 \mathrm{~Hz}, 1 \mathrm{H}), 1.11(\mathrm{~s}, 9 \mathrm{H}) ;{ }^{13} \mathrm{C} \mathrm{NMR}\left(75 \mathrm{MHz}, \mathrm{CDCl}_{3}\right): \delta 173.1,135.4,133.2$, 129.7, 127.7, 68.6, 67.0, 61.1, 53.4, 34.9, 31.7, 26.8, 19.2; HRMS calcd for $\mathrm{C}_{22} \mathrm{H}_{31} \mathrm{NO}_{4} \mathrm{Si}$ : 344.1322, found 344.1318 .

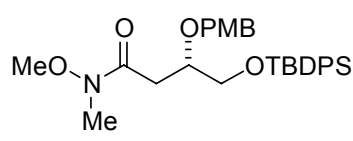

(3S)-4-(tert-Butyldiphenylsilanyloxy)- $N$-methoxy-(4-methoxybenzyloxy)- $N$ methylbutyramide (17): To a solution of $0.511 \mathrm{~g}$ of the $\beta$-hydroxyl amide (prepared above, $1.27 \mathrm{mmol}$ ) in $2.5 \mathrm{~mL}$ of diethyl ether was added $0.790 \mathrm{~mL}$ of $p$-methoxybenzyltrichloroacetimidate $(3.82 \mathrm{mmol})$ and $0.010 \mathrm{~mL}$ of trifluoromethanesulfonic acid via syringe. After stirring for $30 \mathrm{~min}$ at ambient temperature, $5 \mathrm{~mL}$ of saturated aqueous $\mathrm{NaHCO}_{3}$ was added to the reaction. The aqueous and organic layers were separated and the aqueous layer was extracted with diethyl ether $(2 \times 10 \mathrm{~mL})$. The combined organic layers were dried over $\mathrm{MgSO}_{4}$, filtered, 
and concentrated. The crude product mixture was purified by silica gel chromatography $(20 \%$ EtOAc/hexane); elution of the title compound was coincident with trichloroacetamide. The isolated product was triturated from the solid trichloroacetamide using pentane $(5 \times 10 \mathrm{~mL})$. The combined pentane washings were concentrated to provide $0.50 \mathrm{~g}(77 \%)$ of 17 as a colorless oil. $[\alpha]_{\mathrm{D}}=-9.5(c$ 1.1, $\mathrm{CHCl}_{3}$ ); IR (thin film): 3006, 2954, 2931, 2851, 1707, 1655, 1509, 1461, 1422, 1244, 1109, 820, 756, $701 \mathrm{~cm}^{-1} ;{ }^{1} \mathrm{H}$ NMR $\left(\mathrm{CDCl}_{3}\right): \delta 7.68(\mathrm{dd}, J=1.1,7.5 \mathrm{~Hz}, 4 \mathrm{H}), 7.46-7.35(\mathrm{~m}, 6 \mathrm{H}), 7.21(\mathrm{~d}, J=8.6$ $\mathrm{Hz}, 2 \mathrm{H}), 6.83(\mathrm{~d}, J=8.6 \mathrm{~Hz}, 2 \mathrm{H}), 4.53(\mathrm{dd}, J=5.7,16.5 \mathrm{~Hz}, 2 \mathrm{H}), 4.12(\mathrm{~m}, 1 \mathrm{H}), 3.79(\mathrm{~s}, 3 \mathrm{H}), 3.76(\mathrm{dd}$, $J=5.2,7.2 \mathrm{~Hz}, 1 \mathrm{H}), 3.68(\mathrm{dd}, J=5.2,8.8 \mathrm{~Hz}, 1 \mathrm{H}), 3.61(\mathrm{~s}, 3 \mathrm{H}), 3.20(\mathrm{~s}, 3 \mathrm{H}), 2.95-2.55(\mathrm{~m}, 2 \mathrm{H}), 1.06$ $(\mathrm{s}, 9 \mathrm{H}) ;{ }^{13} \mathrm{C} \mathrm{NMR}\left(\mathrm{CDCl}_{3}\right): \delta 172.4,156.8,135.6,133.3,130.9,129.7,129.4,127.7,113.6,76.5,72.3$, 65.6, 61.2, 55.2, 34.7, 32.0, 26.8, 19.2; HRMS calcd for $\mathrm{C}_{30} \mathrm{H}_{39} \mathrm{NO}_{5} \mathrm{Si}$ : 464.1893, found 464.1893.

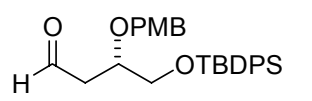

(3S)-4-(tert-Butyldiphenylsilanyloxy)-(4-methoxybenzyloxy) butyraldehyde: To a $-78{ }^{\circ} \mathrm{C}$ solution of $61 \mathrm{mg}$ of $17(0.117 \mathrm{mmol})$ in $1.0 \mathrm{~mL}$ of THF was added 0.129 $\mathrm{mL}$ of DIBAL-H $(0.129 \mathrm{mmol})$ as a $1 \mathrm{M}$ solution in hexanes. After stirring at $-78^{\circ} \mathrm{C}$ for $45 \mathrm{~min}$, the reaction was poured into $5 \mathrm{~mL}$ of a $0{ }^{\circ} \mathrm{C}$ mixture of $1: 1$ diethyl ether and $1 \mathrm{M} \mathrm{HCl}$. The resulting biphasic mixture was stirred at ambient temperature for $30 \mathrm{~min}$. The ether layer was separated and washed with brine (1X5 mL). The organic portion was dried over $\mathrm{MgSO}_{4}$, filtered, and concentrated. The crude product mixturewas purified by silica gel chromatography $(20 \% \mathrm{EtOAc} / \mathrm{hexanes})$ to provide $0.044 \mathrm{~g}(80 \%)$ of the title aldehyde as a colorless oil. $[\alpha]_{\mathrm{D}}=-20\left(c 0.7, \mathrm{CHCl}_{3}\right)$; IR (thin film): 3065 , 3050, 2994, 2954, 2931, 2855, 2725, 1723, 1608, 1584, 1513, 1469, 1422, 1248, 1113, 1034, 820, 737 , $705 \mathrm{~cm}^{-1} ;{ }^{1} \mathrm{H} \mathrm{NMR}\left(\mathrm{CDCl}_{3}\right): \delta 9.78(\mathrm{t}, J=2.0 \mathrm{~Hz}, 1 \mathrm{H}), 7.67(\mathrm{dd}, J=1.7,6.1 \mathrm{~Hz}, 4 \mathrm{H}), 7.43-7.37(\mathrm{~m}$, $6 \mathrm{H}), 7.19(\mathrm{~d}, J=8.6 \mathrm{~Hz}, 2 \mathrm{H}), 6.85(\mathrm{~d}, J=8.6 \mathrm{~Hz}, 2 \mathrm{H}), 4.48(\mathrm{dd}, J=11.1,34.1 \mathrm{~Hz}, 2 \mathrm{H}), 4.03(\mathrm{~m}, J=$ $5.5 \mathrm{~Hz}, 1 \mathrm{H}), 3.80(\mathrm{~s}, 3 \mathrm{H}), 3.77(\mathrm{dd}, J=4.9,10.6 \mathrm{~Hz}, 1 \mathrm{H}), 3.67(\mathrm{dd}, J=5.7,10.5 \mathrm{~Hz}, 1 \mathrm{H}), 2.70(\mathrm{dd}, J=$ $1.9,6.1 \mathrm{~Hz}, 2 \mathrm{H}), 1.06(\mathrm{~s}, 9 \mathrm{H}) ;{ }^{13} \mathrm{C} \mathrm{NMR}\left(\mathrm{CDCl}_{3}\right): \delta 201.4,159.4,135.7,133.2,130.3,130.0,129.5$, 127.9, 113.9, 74.6, 71.9, 65.3, 55.3, 46.4, 26.9, 19.3; EI-MS (70 eV) $419\left(\mathrm{M}^{+}-\mathrm{CH}_{2} \mathrm{CHO}\right), 405\left(\mathrm{M}^{+}-\right.$ $\left.{ }^{t} \mathrm{Bu}\right), 391,333,327,309,267,241,199,181,163,135,121,105$.

(2E)(5S)-6-(tert-Butyldiphenylsilanyloxy)-(4-methoxybenzyloxy)hex-2-

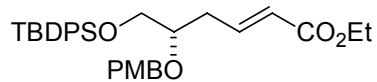
enoic acid, ethyl ester: To a $0{ }^{\circ} \mathrm{C}$ suspension of $1.06 \mathrm{~g}$ of methyltriphenylphosphonium bromide $(3.0 \mathrm{mmol})$ in $5 \mathrm{~mL}$ of THF was added via syringe $4.53 \mathrm{~mL}$ of KHMDS $(2.27 \mathrm{mmol})$ as a $0.5 \mathrm{M}$ solution in toluene. To the resulting orange solution was added via cannula $0.70 \mathrm{~g}$ of the aldehyde (prepared above; $1.5 \mathrm{mmol}$ ) as a solution in $5 \mathrm{~mL}$ of THF. The reaction mixture was warmed to room temperature and stirred for $1 \mathrm{~h}$. The reaction mixture was concentrated and purified by silica gel chromatography $(25 \% \mathrm{EtOAc/hexanes})$ to provide $0.758 \mathrm{~g}(95 \%)$ of the title $(E)$-enoate ester as a colorless oil. $[\alpha]_{\mathrm{D}}=-16\left(c 2.5, \mathrm{CHCl}_{3}\right)$; IR (thin film): 3069, 3050, 2954, 2931, 2851, 1719, 1655, 1612, 1584, 1513, 1469, 1430, 1362, 1299, 1248, 1172, 1113, 1034, 820, 741, 705, $610 \mathrm{~cm}^{-1} ;{ }^{1} \mathrm{H} \mathrm{NMR}\left(\mathrm{CDCl}_{3}\right): \delta 7.67(\mathrm{~d}, J=6.8 \mathrm{~Hz}, 4 \mathrm{H}), 7.56-$ $7.40(\mathrm{~m}, 6 \mathrm{H}), 7.20(\mathrm{~d}, J=8.6 \mathrm{~Hz}, 2 \mathrm{H}), 6.95(\mathrm{ddd}, J=7.9,7.9,15.6 \mathrm{~Hz}, 1 \mathrm{H}), 6.85(\mathrm{~d}, J=8.6 \mathrm{~Hz}, 2 \mathrm{H})$, $5.87(\mathrm{~d}, J=15.6 \mathrm{~Hz}, 1 \mathrm{H}), 4.46(\mathrm{dd}, J=11.4,31.2 \mathrm{~Hz}, 2 \mathrm{H}), 4.20(\mathrm{q}, J=7.0 \mathrm{~Hz}, 2 \mathrm{H}), 3.81(\mathrm{~s}, 3 \mathrm{H}), 3.74$ (m, 1H), 3.60 (dd, $J=5.2,6.0 \mathrm{~Hz}, 2 \mathrm{H}), 2.49$ (dd, $J=6.9,14.3 \mathrm{~Hz}, 2 \mathrm{H}), 1.35$ (t, $J=7.2 \mathrm{~Hz}, 3 \mathrm{H}), 1.06$ $(\mathrm{s}, 9 \mathrm{H}) ;{ }^{13} \mathrm{C} \mathrm{NMR}\left(\mathrm{CDCl}_{3}\right): \delta 166.5,159.3,145.5,135.7,133.4,133.3,130.5,129.9,129.5,127.9$, 123.6, 113.8, 78.1, 71.8, 65.4, 60.3, 55.3, 34.8, 26.9, 19.3, 14.4; EI-MS (70 eV) $475\left(\mathrm{M}^{+}{ }^{-t} \mathrm{Bu}\right), 429,337$ (475-OPMB), 309, 267, 241, 227, 223, 199, 121 (PMB). 


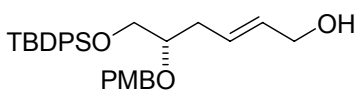

DIBAL-H (1.29 mmol).

\section{(2E)(5S)-6-(tert-Butyldiphenylsiloxy)-(4-methoxybenzyloxy)hex-2-en-1-ol:} To a $-78{ }^{\circ} \mathrm{C}$ solution of $0.328 \mathrm{~g}$ of the $(E)$-enoate ester (prepared above; 0.617 $\mathrm{mmol}$ ) in $3.1 \mathrm{~mL}$ of THF was added $1.3 \mathrm{~mL}$ of a $1 \mathrm{M}$ hexanes solution of reaction mixture was poured into a $0{ }^{\circ} \mathrm{C}$ mixture of $10 \mathrm{~mL}$ of diethylether and $10 \mathrm{~mL}$ of $1 \mathrm{M} \mathrm{HCl}$ and the resulting biphasic mixture was stirred for $15 \mathrm{~min}$. The organic and aqueous layers were separated and the aqueous layer was saturated with brine and extracted with diethylether $(3 \times 10 \mathrm{~mL})$. The combined organics were dried over $\mathrm{MgSO}_{4}$, filtered, and concentrated. The crude product mixture was purified by silica gel chromatography (15\% EtOAc/hexanes) to provide $0.267 \mathrm{~g}(89 \%)$ of the title allylic alcohol as a colorless oil. $[\alpha]_{\mathrm{D}}=-13\left(c 1.1, \mathrm{CHCl}_{3}\right)$; IR (thin film): 3418, 3065, 3046, 2954, 2931, 2851, 1612, 1509, 1461, 1422, 1244, 1109, 1030, 820, 741, $701 \mathrm{~cm}^{-1} ;{ }^{1} \mathrm{H} \mathrm{NMR}\left(\mathrm{CDCl}_{3}\right): \delta 7.68$ $(\mathrm{d}, J=6.2 \mathrm{~Hz}, 4 \mathrm{H}), 7.44-7.36(\mathrm{~m}, 6 \mathrm{H}), 7.23(\mathrm{~d}, J=8.5 \mathrm{~Hz}, 2 \mathrm{H}), 6.86(\mathrm{~d}, J=8.5 \mathrm{~Hz}, 2 \mathrm{H}), 5.66-5.63$ $(\mathrm{m}, 2 \mathrm{H}), 4.51(\mathrm{dd}, J=11.3,34.1 \mathrm{~Hz}, 2 \mathrm{H}), 4.04(\mathrm{dd}, J=4.3,9.4 \mathrm{~Hz}, 2 \mathrm{H}), 3.81(\mathrm{~s}, 3 \mathrm{H}), 3.72(\mathrm{dd}, J=$ 5.7, $10.7 \mathrm{~Hz}, 1 \mathrm{H}), 3.64(\mathrm{dd}, J=5.1,10.5 \mathrm{~Hz}, 1 \mathrm{H}), 3.53(\mathrm{dd}, J=5.5,5.5 \mathrm{~Hz}, 1 \mathrm{H}), 2.34(\mathrm{ddd}, J=6.6$, 9.2, $9.9 \mathrm{~Hz}, 2 \mathrm{H}), 1.07(\mathrm{~s}, 9 \mathrm{H}) ;{ }^{13} \mathrm{C} \mathrm{NMR}\left(\mathrm{CDCl}_{3}\right): \delta 159.2,135.8,135.7,133.6,133.5,131.7,130.9$, 129.9, 129.8, 129.6, 129.5, 128.7, 127.8, 113.8, 79.0, 71.6, 65.5, 63.6, 55.3, 34.4, 27.0, 19.3; EI-MS (70 eV) $433\left(\mathrm{M}^{+}{ }^{-} \mathrm{Bu}\right), 415\left(433-\mathrm{H}_{2} \mathrm{O}\right), 333,295,279,241,223,211,199,181,163,135,121,105$.

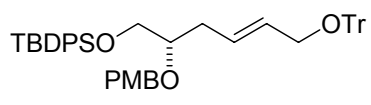

triphenylmethylether (18): To a solution of $0.181 \mathrm{~mL}$ of 2,6-lutidine $(1.56$ iodide $(1.04 \mathrm{mmol})$ in $2 \mathrm{~mL}$ of $\mathrm{CH}_{2} \mathrm{Cl}_{2}$ was added a solution of $0.508 \mathrm{~g}$ of allylic alcohol (prepared above; $1.04 \mathrm{mmol}$ ) in $1 \mathrm{~mL} \mathrm{CH}_{2} \mathrm{Cl}_{2}$ via syringe. The golden-brown reaction mixture was stirred at room temperature for $5.5 \mathrm{~h}$. The reaction mixture was then concentrated and purified by silica gel chromatography (10/90 EtOAc/hexanes) to provide $0.678 \mathrm{~g}(92 \%)$ of 18 as a colorless oil. IR (thin film): 3057, 3026, 2955, 2927, 2856, 1960, 1881, 1818, 1616, 1509, 1450, 1426, 1386, 1362, 1299 , 1248, 1176, 1109, 1054, 1034, 820, 760, 744, $700 \mathrm{~cm}^{-1} ;{ }^{1} \mathrm{H} \mathrm{NMR}\left(\mathrm{CDCl}_{3}\right): \delta 7.74(\mathrm{~d}, J=6.5 \mathrm{~Hz}, 4 \mathrm{H})$, $7.53(\mathrm{~d}, J=7.3 \mathrm{~Hz}, 6 \mathrm{H}), 7.48-7.28(\mathrm{~m}, 15 \mathrm{H}), 6.86(\mathrm{~d}, J=8.5 \mathrm{~Hz}, 2 \mathrm{H}), 5.88-5.65(\mathrm{~m}, 2 \mathrm{H}), 4.58(\mathrm{dd}$, $J=11.3,26.5 \mathrm{~Hz}, 2 \mathrm{H}), 3.87-3.65(\mathrm{~m}, 3 \mathrm{H}), 3.83(\mathrm{~s}, 3 \mathrm{H}), 3.60(\mathrm{~d}, J=4.6 \mathrm{~Hz}, 2 \mathrm{H}), 2.43$ (ddd, $J=6.4$, 9.63, $10.0 \mathrm{~Hz}, 2 \mathrm{H}), 1.13(\mathrm{~s}, 9 \mathrm{H}) ;{ }^{13} \mathrm{CNMR}\left(\mathrm{CDCl}_{3}\right): \delta 159.2,144.6,135.8,133.7,131.1,130.0,129.8$, $129.5,129.4,128.8,128.6,128.0,127.9,127.1,113.9,86.9,79.3,71.8,65.7,65.0,55.4,34.9,27.0$, 19.4 .

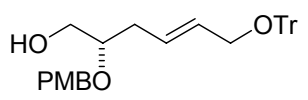

$(4 E)(2 S)-(4-m e t h o x y b e n z y l o x y)-6-(t r i p h e n y l m e t h y l o x y) h e x-4-e n-1-o l: \quad$ To a solution of $100 \mathrm{mg}$ of $18(0.137 \mathrm{mmols})$ in $1.4 \mathrm{~mL}$ of THF was added $0.164 \mathrm{~mL}$ of tetrabutylammonium fluoride $(0.164 \mathrm{mmol})$ as a $1 \mathrm{M}$ solution in THF via syringe. The reaction was maintained for $2 \mathrm{~h}$ at ambient temperature, then added directly to a silica gel column and eluted with $30 \% \mathrm{EtOAc} /$ hexanes to afford $67 \mathrm{mg}(99 \%)$ of the title alcohol as a colorless oil. $[\alpha]_{\mathrm{D}}=8.0(0.8$, $\mathrm{CHCl}_{3}$ ); IR (thin film): 3434, 3081, 3061, 3030, 2931, 2867, 1640, 1612, 1513, 1446, 1244, 1172 , 1030, 824, 745, $709 \mathrm{~cm}^{-1} ;{ }^{1} \mathrm{H}$ NMR $\left(\mathrm{CDCl}_{3}\right): \delta 7.48(\mathrm{~d}, J=7.2 \mathrm{~Hz}, 6 \mathrm{H}), 7.35-7.23(\mathrm{~m}, 11 \mathrm{H}), 6.89(\mathrm{~d}, J$ $=6.6 \mathrm{~Hz}, 2 \mathrm{H}), 5.95-5.65(\mathrm{~m}, 2 \mathrm{H}), 4.57(\mathrm{dd}, J=11.1,41.0 \mathrm{~Hz}, 2 \mathrm{H}), 3.80(\mathrm{~s}, 3 \mathrm{H}), 3.74-3.40(\mathrm{~m}, 3 \mathrm{H})$,

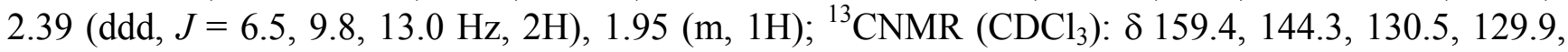
129.6, 128.8, 128.0, 127.6, 127.1, 114.1, 86.9, 79.1, 71.5, 64.8, 64.3, 55.4, 34.2; HRMS calcd for $\mathrm{C}_{33} \mathrm{H}_{34} \mathrm{O}_{4}$ : 493.2373, found 493.2379. 
PMBÖ $\mathrm{OHT}$

(4E)(2S)-(4-methoxybenzyloxy)-6-(triphenylmethyloxy)hex-4-en-1-al (15): To a solution of $0.133 \mathrm{~g}$ of the alcohol $(0.19 \mathrm{mmol})$ in $15 \mathrm{~mL}$ of $\mathrm{CH}_{2} \mathrm{Cl}_{2}$ at ambient temperature was added $0.094 \mathrm{~g}$ of Dess-Martin periodinane $(0.22 \mathrm{mmol})$ portionwise. The resulting turbid white mixture was stirred $30 \mathrm{~min}$. Saturated aqueous $\mathrm{NaHCO}_{3}(5 \mathrm{~mL})$ was added and the mixture was extracted with $\mathrm{CH}_{2} \mathrm{Cl}_{2}(3 \times 15 \mathrm{~mL})$. The combined organics were washed with brine (15 mL), dried over $\mathrm{MgSO}_{4}$, filtered, and concentrated. The crude product was purified by flash chromatography on silica gel $(20 \% \mathrm{EtOAc} / \mathrm{Hex})$ to afford $0.124 \mathrm{~g}(94 \%)$ of 15 as a colorless oil. $[\alpha]_{\mathrm{D}}$ $=-8\left(0.8, \mathrm{CHCl}_{3}\right)$; IR (thin film): 3550, 3085, 3058, 3032, 2932, 2860, 1732, 1612, 1513, 1490, 1448, 1248, 1174, 1035, 763, 738, $706 \mathrm{~cm}^{-1} ;{ }^{1} \mathrm{H}$ NMR (300 MHz, $\left.\mathrm{CDCl}_{3}\right): \delta 9.67(\mathrm{~d}, J=1.9 \mathrm{~Hz}, 1 \mathrm{H}), 7.49$ $(\mathrm{d}, J=7.2 \mathrm{~Hz}, 6 \mathrm{H}), 7.42-7.18(\mathrm{~m}, 11 \mathrm{H}), 6.89(\mathrm{~d}, J=8.5 \mathrm{~Hz}, 2 \mathrm{H}), 5.90-5.71(\mathrm{~m}, 2 \mathrm{H}), 4.62(\mathrm{dd}, J=$ 11.3, 21.7 Hz, 2H), 3.88-3.73 (m, 4H), $3.61(\mathrm{~d}, J=4.2 \mathrm{~Hz}, 2 \mathrm{H}), 2.51(\mathrm{~m}, 2 \mathrm{H}) ;{ }^{13} \mathrm{C} \mathrm{NMR}(75 \mathrm{MHz}$, $\left.\mathrm{CDCl}_{3}\right): \delta 203.5,144.3,134.9,130.8,129.9,129.7,128.8,128.0,128.0,127.3,127.1,125.9,114.1$, 87.0, 82.8, 72.4, 64.7, 55.4, 33.6, 29.9. FAB-MS e/v $515(\mathrm{M}+\mathrm{Na})^{+}$.

(3S)-E-5-Methyl-1-tributylstannanylhexa-1,5-dien-3-ol: To a $-78{ }^{\circ} \mathrm{C}$ solution of $\beta$-tributylstannyl acrolein $(0.290 \mathrm{mmol})$ slowly dropwise. The resulting colorless solution was maintained for $1 \mathrm{~h}$ at $-78{ }^{\circ} \mathrm{C}$ and then slowly warmed to $0{ }^{\circ} \mathrm{C}$. An aqueous solution of $3 \mathrm{~N} \mathrm{NaOH}(0.3$ $\mathrm{mL})$ and $30 \% \mathrm{H}_{2} \mathrm{O}_{2}(0.3 \mathrm{~mL})$ were added, the colorless, biphasic solution was then stirred for $2 \mathrm{~h}$ at ambient temperature. The mixture was extracted with $\mathrm{Et}_{2} \mathrm{O}(3 \times 10 \mathrm{~mL})$. The combined organics were washed with brine $(10 \mathrm{~mL})$, dried over $\mathrm{MgSO}_{4}$, filtered, and concentrated. The crude product was purified by flash chromatography on silica gel (2\% EtOAc/Hex) to afford $0.112 \mathrm{~g}(96 \%)$ of the homoallylic alcohol as a colorless oil. The enantiomeric purity of this compound ws determined using the procedure outlined below. $[\alpha]_{\mathrm{D}}=-9.3\left(\mathrm{c} \mathrm{1.1,} \mathrm{CHCl}_{3}\right)$; IR (thin film): 3365, 2957, 2926, 2871, 2853, 1460, 1376, 1073, 989, $889 \mathrm{~cm}^{-1}$; ${ }^{1} \mathrm{H}$ NMR (300 MHz, $\left.\mathrm{CDCl}_{3}\right): \delta 6.12(\mathrm{dd}, J=1.1,19.1 \mathrm{~Hz}, 1 \mathrm{H})$, $6.04(\mathrm{dd}, J=5.1,19.1 \mathrm{~Hz}, 1 \mathrm{H}), 4.86(\mathrm{dd}, J=1.2,79.5 \mathrm{~Hz}, 1 \mathrm{H}), 4.24-4.23(\mathrm{~m}, 1 \mathrm{H}), 2.28-2.24(\mathrm{~m}, 2 \mathrm{H})$, $1.93(\mathrm{~d}, J=3.4 \mathrm{~Hz}, 1 \mathrm{H}), 1.80(\mathrm{~s}, 3 \mathrm{H}), 1.55-1.47(\mathrm{~m}, 6 \mathrm{H}), 1.36-1.34(\mathrm{~m}, 6 \mathrm{H}), 0.94-0.89(\mathrm{~m}, 14 \mathrm{H}) ;{ }^{13} \mathrm{C}$ NMR $\left(75 \mathrm{MHz}, \mathrm{CDCl}_{3}\right): \delta 150.1,142.2,127.6,113.6,72.4,46.0,30.0,27.2,22.4,13.6,9.4$; HRMS calcd for $\mathrm{C}_{15} \mathrm{H}_{29} \mathrm{OSn}\left[\mathrm{M}-{ }^{n} \mathrm{Bu}\right]^{+}: 345.1240$, found 345.1251 .

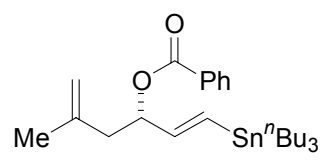

(3S)-E-Benzoic acid, 3-methyl-1-(2-tributylstannanylvinyl)but-3-enyl ester (enantiomeric purity assay): To a solution of $0.092 \mathrm{~g}$ of the homoallylic alcohol (prepared above; $0.23 \mathrm{mmol}$ ) in $0.1 \mathrm{~mL}$ pyridine was added $0.03 \mathrm{~mL}$ of benzoyl chloride $(0.28 \mathrm{mmol})$ and $0.001 \mathrm{~g}$ of DMAP $(0.01 \mathrm{mmol})$ sequentially. The resulting white suspension was maintained for $20 \mathrm{~min}$ at ambient temperature. The reaction mixture was quenched with saturated $\mathrm{NaHCO}_{3}(2 \mathrm{~mL})$, and the aqueous layer was extracted with $\mathrm{Et}_{2} \mathrm{O}(3 \times 6$ $\mathrm{mL})$. The combined organics were washed with brine $(4 \mathrm{~mL})$, dried over $\mathrm{MgSO}_{4}$, filtered, and concentrated. The crude product was purified by flash chromatography on silica gel (2\% EtOAc/Hex) to afford $0.113 \mathrm{~g}(97 \%)$ of the title ester as a colorless oil. $[\alpha]_{\mathrm{D}}=-9.2\left(c 7.1, \mathrm{CHCl}_{3}\right)$; IR (thin film): 2956, 2926, 2871, 2853, 1721, 1271, 1111, $710 \mathrm{~cm}^{-1} ;{ }^{1} \mathrm{H}$ NMR $\left(300 \mathrm{MHz}, \mathrm{CDCl}_{3}\right): \delta 8.11(\mathrm{~d}, J=8.5$ $\mathrm{Hz}, 2 \mathrm{H}), 7.59(\mathrm{~m}, 1 \mathrm{H}), 7.50-7.45(\mathrm{~m}, 2 \mathrm{H}), 6.32(\mathrm{~d}, J=18.9 \mathrm{~Hz}, 1 \mathrm{H}), 6.07(\mathrm{dd}, J=5.5,19.1 \mathrm{~Hz}, 1 \mathrm{H})$, 5.70-5.68 (m, 1H), $4.83(\mathrm{~s}, 1 \mathrm{H}), 2.57-2.48(\mathrm{~m}, 2 \mathrm{H}), 1.84(\mathrm{~s}, 1 \mathrm{H}), 1.53(\mathrm{~m}, 6 \mathrm{H}), 1.33(\mathrm{~m}, 7 \mathrm{H}), 0.91(\mathrm{~m}$, $14 \mathrm{H}) ;{ }^{13} \mathrm{C} \mathrm{NMR}\left(75 \mathrm{MHz}, \mathrm{CDCl}_{3}\right): \delta 165.7,145.3,141.1,132.7,130.6,129.6,128.3,113.6,75.3,43.1$, 29.0, 27.6, 27.2, 22.6, 13.7, 9.4; HRMS calcd for $\mathrm{C}_{22} \mathrm{H}_{33} \mathrm{O}_{2} \mathrm{Sn}\left[\mathrm{M}-{ }^{n} \mathrm{Bu}\right]^{+}:$449.1503, found 449.1484. Separation of the enantiomers by chiral HPLC [Daicel Chiracel ${ }^{\circledR}$ OD-H column, flow rate $0.5 \mathrm{~mL} / \mathrm{min}$, 
$0.5 \%{ }^{i} \mathrm{PrOH}, 99.5 \%$ hexane, $\left.\operatorname{Tr}: 9.7 \mathrm{~min}(R), 10.8 \mathrm{~min}(S)\right]$ provided the enantiomer ratio: $3 S: 3 R=98$ : 1 (98\%ee). ((3S)-E-3-Allyloxy-5-methylhexa-1,5-dienyl)tributylstannane (21):
$-78{ }^{\circ} \mathrm{C}$ solution of $0.662 \mathrm{~g}$ of the homoallylic alcohol (prepared above; 1.65
$\mathrm{mmol})$ in $10 \mathrm{~mL}$ of $\mathrm{THF}$ was added $7.90 \mathrm{~mL}$ of a $0.5 \mathrm{M}$ toluene solution of KHMDS (1.82 mmol) slowly dropwise. After $15 \mathrm{~min}, 0.94 \mathrm{~mL}$ of allyl bromide (4.95 mmol) was added and the resulting solution was warmed to ambient temperature and maintained for $2 \mathrm{~h}$. The reaction was quenched with brine and the aqueous layer was extracted with $\mathrm{Et}_{2} \mathrm{O}(3 \times 12 \mathrm{~mL})$. The combined organics were dried over $\mathrm{MgSO}_{4}$, filtered, and concentrated. The crude product was purified by flash chromatography ( $2 \%$ EtOAc/hexanes) to afford $0.699 \mathrm{~g}(97 \%)$ of 21 as a colorless oil. [ $\alpha]_{\mathrm{D}}=$ -38 (c 2.3, $\mathrm{CHCl}_{3}$ ); IR (thin film): 3077, 2957, 2926, 2871, 2852, 1460, 1077, 992, 920, $888 \mathrm{~cm}^{-1} ;{ }^{1} \mathrm{H}$ NMR $\left(300 \mathrm{MHz}, \mathrm{CDCl}_{3}\right): \delta 6.10(\mathrm{~d}, J=9.5 \mathrm{~Hz}, 1 \mathrm{H}), 5.96-5.87(\mathrm{~m}, 1 \mathrm{H}), 5.79(\mathrm{dd}, J=7.2,19.0 \mathrm{~Hz}$, $1 \mathrm{H}), 5.25(\mathrm{dd}, J=1.6,17.1 \mathrm{~Hz}, 1 \mathrm{H}), 5.15(\mathrm{~d}, J=10.4 \mathrm{~Hz}, 2 \mathrm{H}), 4.75(\mathrm{~d}, J=10.8 \mathrm{~Hz}, 1 \mathrm{H}), 4.06(\mathrm{dd}, J=$ 5.2, $12.8 \mathrm{~Hz}, 1 \mathrm{H}), 3.87-3.79(\mathrm{~m}, 2 \mathrm{H}), 2.39(\mathrm{dd} J=7.1,13.9 \mathrm{~Hz}, 1 \mathrm{H}), 2.21(\mathrm{dd}, J=6.3,13.9 \mathrm{~Hz}, 1 \mathrm{H})$, $1.75(\mathrm{~s}, 3 \mathrm{H}), 1.56-1.46(\mathrm{~m}, 6 \mathrm{H}), 1.37-1.25(\mathrm{~m}, 7 \mathrm{H}), 0.96-0.82(\mathrm{~m}, 14 \mathrm{H}) ;{ }^{13} \mathrm{C} \mathrm{NMR}\left(75 \mathrm{MHz}, \mathrm{CDCl}_{3}\right)$ : $\delta$ 148.4, 142.2, 135.1, 131.2, 116.5, 112.6, 82.0, 69.1, 44.0, 29.1, 27.2, 22.9, 13.7, 9.4; HRMS calcd for $\mathrm{C}_{18} \mathrm{H}_{33} \mathrm{OSn}\left[\mathrm{M}-{ }^{n} \mathrm{Bu}\right]^{+}: 377.1580$, found 377.1597 .

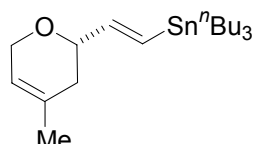

Tributyl-[(E)-2-((2S)-4-methyl-3,6-dihydro-2H-pyran-2-yl)vinyl]stannane (22): To a $25{ }^{\circ} \mathrm{C}$ solution of $0.081 \mathrm{~g}$ of freshly prepared Schrock's catalyst $(0.11 \mathrm{mmol})^{3}$ in $11 \mathrm{~mL}$ of degassed toluene was added $0.661 \mathrm{~g}$ of 21 (1.5 mmol). After maintaining the reaction at ambient temperature for $25 \mathrm{~min}$, to the resulting dark brown solution was added another portion of $0.081 \mathrm{~g}$ of Schrock's catalyst $(0.11 \mathrm{mmol})$. After $30 \mathrm{~min}$, the reaction was exposed to air for $2 \mathrm{~h}$. The reaction mixture was concentrated and the crude product was purified by flash chromatography $\left(0.6 \%\right.$ EtOAc/hexanes) to afford $0.465 \mathrm{~g}(81 \%)$ of 22 as a brown oil. $[\alpha]_{\mathrm{D}}=-73$ (c 1.1, $\mathrm{CHCl}_{3}$ ); IR (thin film): 2957, 2926, 2872, 2851, 1460, 1378, 1123, $988 \mathrm{~cm}^{-1} ;{ }^{1} \mathrm{H}$ NMR (300 $\left.\mathrm{MHz}, \mathrm{CDCl}_{3}\right): \delta 6.25(\mathrm{~d}, J=19.2 \mathrm{~Hz}, 1 \mathrm{H}), 6.09(\mathrm{dd}, J=4.8,19.2 \mathrm{~Hz}, 1 \mathrm{H}), 5.43(\mathrm{~s}, 1 \mathrm{H}), 4.22(\mathrm{~s}, 2 \mathrm{H})$, $4.00(\mathrm{~m}, 1 \mathrm{H}), 2.10-1.91(\mathrm{~m}, 2 \mathrm{H}), 1.73(\mathrm{~s}, 3 \mathrm{H}), 1.61-1.47(\mathrm{~m}, 6 \mathrm{H}), 1.39-1.27(\mathrm{~m}, 6 \mathrm{H}), 0.94-0.86(\mathrm{~m}$, $15 \mathrm{H}) ;{ }^{13} \mathrm{C}$ NMR $\left(75 \mathrm{MHz}, \mathrm{CDCl}_{3}\right): \delta 148.3,131.5,128.5,119.6,76.4,65.6,35.5,29.0,27.2,22.9$, 13.6, 9.3; HRMS calcd for $\mathrm{C}_{16} \mathrm{H}_{29} \mathrm{OSn}\left[\mathrm{M}-{ }^{n} \mathrm{Bu}\right]^{+}: 357.1240$, found 357.1248.

(2S)-2-[(E)-2-Iodovinyl]-4-methyl-3,6-dihydro-2H-pyran (23): To a $-20{ }^{\circ} \mathrm{C}$ solution of $0.226 \mathrm{~g}$ of $22(0.55 \mathrm{mmol})$ in $10 \mathrm{~mL}$ of THF was slowly added a solution of $0.123 \mathrm{~g}$ of NIS $(0.55 \mathrm{mmol})$ in $0.8 \mathrm{~mL}$ of THF dropwise. After stirring $30 \mathrm{~min}$ at $-20{ }^{\circ} \mathrm{C}$, the resulting yellow solution was poured into brine $(6 \mathrm{~mL})$ and the mixture was extracted with $\mathrm{Et}_{2} \mathrm{O}(3 \times 15$ $\mathrm{mL})$. The combined organics was washed with saturated $\mathrm{Na}_{2} \mathrm{~S}_{2} \mathrm{O}_{3}(8 \mathrm{~mL})$, dried over $\mathrm{MgSO}_{4}$, filtered, and concentrated. The crude product was purified by flash chromatography $\left(10 \% \mathrm{CH}_{2} \mathrm{Cl}_{2} /\right.$ pentane) to afford $0.131 \mathrm{~g}(96 \%)$ of 23 as a yellow oil. $[\alpha]_{\mathrm{D}}=-106\left(c 0.76, \mathrm{CHCl}_{3}\right)$; IR (thin film): 3026, 2963, 2908, 2823, 1381, 1368, 1124, 1059, 1013, 667, $682 \mathrm{~cm}^{-1} ;{ }^{1} \mathrm{H}$ NMR $\left(300 \mathrm{MHz}, \mathrm{CDCl}_{3}\right): \delta 6.61(\mathrm{dd}, J=$ $5.5,14.5 \mathrm{~Hz}, 1 \mathrm{H}), 6.39(\mathrm{dd}, J=0.9,14.6 \mathrm{~Hz}, 1 \mathrm{H}), 5.39(\mathrm{~s}, 1 \mathrm{H}), 4.16(\mathrm{~s}, 2 \mathrm{H}), 3.97$ (m, 1H), 2.04-1.87 $(\mathrm{m}, 2 \mathrm{H}), 1.68(\mathrm{~s}, 3 \mathrm{H}) ;{ }^{13} \mathrm{C} \mathrm{NMR}\left(75 \mathrm{MHz}, \mathrm{CDCl}_{3}\right): \delta 145.9,131.0,119.7,78.0,75.5,65.6,35.0,23.0$; HRMS calcd for $\mathrm{C}_{8} \mathrm{H}_{11} \mathrm{OI}: 249.9855$, found 249.9860 .

\footnotetext{
3 Schrock, R. R.; Murdzek, J. S.; Bazan, G. C.; Robbins, J.; DiMare, M.; O’Regan, M. J. Am. Chem. Soc. 1990, 112,
} 3875 . 


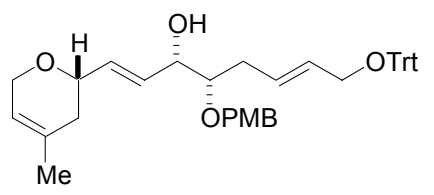

$(1 E, 6 E)(3 S, 4 S)-4-(4-M e t h o x y b e n z y l o x y)-1-[(2 S)-4-m e t h y l-3,6-d i h y d r o-$ 2H-pyran-2-yl]-8-trityloxyocta-1,6-dien-3-ol (24): To a $25^{\circ} \mathrm{C}$ suspension of $0.173 \mathrm{~g}$ of $\mathrm{Mg}$ powder $(7.1 \mathrm{mmol})$ in $5 \mathrm{~mL}$ of $\mathrm{Et}_{2} \mathrm{O}$ was slowly added $0.57 \mathrm{~mL}$ of 1,2-dibromoethane $(6.7 \mathrm{mmol})$ in $1.70 \mathrm{~mL}$ of benzene dropwise.

After the reaction exotherm subsided, the slightly turbid gray solution was stirred for another 30 min and then allowed to stand for $1.5 \mathrm{~h}$ without stirring. The molarity of the resulting $\mathrm{MgBr}_{2}$ is approximately $1.0 \mathrm{M}$.

To a $-78^{\circ} \mathrm{C}$ solution of $0.104 \mathrm{~g}$ of $23(0.42 \mathrm{mmol})$ in $3.5 \mathrm{~mL}$ of $\mathrm{Et}_{2} \mathrm{O}$ was slowly added $0.60 \mathrm{~mL}$ of a $1.39 \mathrm{M}$ pentane solution of ${ }^{t} \mathrm{BuLi}(0.83 \mathrm{mmol})$ dropwise. After maintaining the resulting pale yellow solution at $-78{ }^{\circ} \mathrm{C}$ for $1 \mathrm{~h}, 1.00 \mathrm{~mL}$ of the $1.0 \mathrm{M}$ ethereal magnesium bromide $(1.0 \mathrm{mmol})$ solution (prepared above) was added dropwise. The reaction solvent wes evaporated under reduced pressure maintaining the reaction solution at $-78{ }^{\circ} \mathrm{C}$. The resulting white, solid residue was dissolved by adding $6.0 \mathrm{~mL}$ of $\mathrm{CH}_{2} \mathrm{Cl}_{2}$ cooled to $-78{ }^{\circ} \mathrm{C}$ via cannula. To the resulting clear, colorless solution was added $0.158 \mathrm{~g}$ of $15(0.33 \mathrm{mmol})$ in $0.7 \mathrm{~mL}$ of $\mathrm{CH}_{2} \mathrm{Cl}_{2}$ dropwise. After stirring for $20 \mathrm{~min}$ at $-78{ }^{\circ} \mathrm{C}, 1.5 \mathrm{~mL}$ of water and $2.5 \mathrm{~mL}$ of brine were added to quench the reaction. The aqueous layer was extracted with $\mathrm{CH}_{2} \mathrm{Cl}_{2}(3 \times 10 \mathrm{~mL})$. The combined organics was dried over $\mathrm{MgSO}_{4}$, filtered, and concentrated. The crude product was purified by flash chromatography on silica gel (35\% EtOAc/Hex) to afford $1.910 \mathrm{~g}$ (96\%) of 24 as a colorless oil: $[\alpha]_{\mathrm{D}}=-32\left(c\right.$ 3.0, $\left.\mathrm{CHCl}_{3}\right)$; IR (thin film): 3436, 3013, 2928, 2856, 1513, 1249, 1216, 1034, 757, $705 \mathrm{~cm}^{-1} ;{ }^{1} \mathrm{H}$ NMR $\left(300 \mathrm{MHz}, \mathrm{CDCl}_{3}\right): \delta 7.58-7.56(\mathrm{~m}, 6 \mathrm{H}), 7.38-7.26(\mathrm{~m}$, $11 \mathrm{H}), 6.91(\mathrm{~d}, J=8.4 \mathrm{~Hz}, 2 \mathrm{H}), 5.97-5.78(\mathrm{~m}, 4 \mathrm{H}), 5.48(\mathrm{~s}, 1 \mathrm{H}), 4.65(\mathrm{dd}, J=10.9,44.7 \mathrm{~Hz}, 2 \mathrm{H}), 4.25$ $(\mathrm{s}, 3 \mathrm{H}), 4.14(\mathrm{~m}, 1 \mathrm{H}), 3.78(\mathrm{~s}, 3 \mathrm{H}), 3.69(\mathrm{~d}, J=4.4 \mathrm{~Hz}, 2 \mathrm{H}), 3.52(\mathrm{~m}, 1 \mathrm{H}), 2.93(\mathrm{~s}, 1 \mathrm{H}), 2.56(\mathrm{~m}, 1 \mathrm{H})$, $2.43(\mathrm{~m}, 1 \mathrm{H}), 2.16(\mathrm{~m}, 1 \mathrm{H}), 2.08(\mathrm{~s}, 1 \mathrm{H}), 1.99(\mathrm{~m}, 1 \mathrm{H}), 1.77(\mathrm{~s}, 3 \mathrm{H}) ;{ }^{13} \mathrm{C} \mathrm{NMR}\left(75 \mathrm{MHz}, \mathrm{CDCl}_{3}\right): \delta$ 159.1, 144.1, 133.1, 131.2, 130.0, 129.7, 129.6, 129.4, 128.4, 127.6, 127.5, 126.8, 119.5, 113.7, 86.6, $81.2,73.1,72.1,65.4,64.5,60.2,55.0,35.5,33.4,22.8,20.9,14.0$; FAB-MS elv $639(\mathrm{M}+\mathrm{Na})^{+}$.

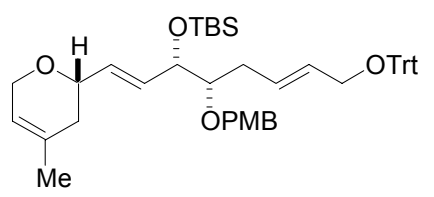

tert-Butyl-\{(4E)(1S, 2S)-2-(4-methoxy-benzyloxy)-1-[(1E)-2-((2S)-4methyl-3,6-dihydro-2H-pyran-2-yl)-vinyl]-6-trityloxy-hex-4-enyloxy\} dimethylsilane: To a $0{ }^{\circ} \mathrm{C}$ solution of $0.682 \mathrm{~g}$ of $24(1.1 \mathrm{mmol})$ and $0.238 \mathrm{~g}$ of imidazole $(3.4 \mathrm{mmol})$ in $5 \mathrm{~mL}$ of DMF was added $0.513 \mathrm{~g}$ of TBSCl (3.4 mmol). The reaction was warmed to ambient temperature and stirred for $4.5 \mathrm{~h}$. The reaction was quenched by adding $15 \mathrm{~mL}$ of saturated $\mathrm{NaHCO}_{3}$ and $20 \mathrm{~mL}$ of EtOAc and the layers were shaken and seperated. The aqueous layer was extracted with EtOAc $(3 \times 15 \mathrm{~mL})$ and the combined organics were washed with brine $(20 \mathrm{~mL})$, dried over $\mathrm{MgSO}_{4}$, filtered, and concentrated. The crude product was purified by flash chromatography $(10 \% \mathrm{EtOAc} / \mathrm{Hex})$ to afford $0.799 \mathrm{~g}(98 \%)$ of the silyl ether as a yellow oil. $[\alpha]_{\mathrm{D}}=-52$ (c 2.1, $\mathrm{CHCl}_{3}$ ); IR (thin film): 3058, 3005, 2954, 2929, 2855, 1513, 1448, 1249, $1105,1036,836,775,758,706,632 \mathrm{~cm}^{-1} ;{ }^{1} \mathrm{H} \mathrm{NMR}\left(300 \mathrm{MHz}, \mathrm{CDCl}_{3}\right): \delta 7.65-7.62(\mathrm{~m}, 6 \mathrm{H}), 7.49-7.37$ $(\mathrm{m}, 11 \mathrm{H}), 6.96(\mathrm{~d}, J=8.6 \mathrm{~Hz}, 2 \mathrm{H}), 6.05-5.77(\mathrm{~m}, 4 \mathrm{H}), 5.58(\mathrm{~s}, 1 \mathrm{H}), 4.73(\mathrm{dd}, J=11.3,19.0 \mathrm{~Hz}, 2 \mathrm{H})$, $4.47(\mathrm{dd}, J=4.6,4.6 \mathrm{~Hz}, 1 \mathrm{H}), 4.30(\mathrm{~s}, 2 \mathrm{H}), 4.20(\mathrm{~m}, 1 \mathrm{H}), 3.90(\mathrm{~s}, 3 \mathrm{H}), 3.71(\mathrm{~d}, J=4.9 \mathrm{~Hz}, 2 \mathrm{H}), 3.54$ $(\mathrm{m}, 1 \mathrm{H}), 2.52(\mathrm{~m}, 1 \mathrm{H}), 2.32-2.21(\mathrm{~m}, 2 \mathrm{H}), 2.07(\mathrm{~m}, 1 \mathrm{H}), 1.06(\mathrm{~s}, 9 \mathrm{H}), 0.2(\mathrm{~s}, 3 \mathrm{H}), 0.19(\mathrm{~s}, 3 \mathrm{H}) ;{ }^{13} \mathrm{C}$ NMR (75 MHz, $\mathrm{CDCl}_{3}$ ): $\delta 159.1,144.3,131.6,131.4,130.8,130.2$ 129.6, 129.4 128.6, 127.7, 126.8, 119.7, 113.7, 86.6, 82.1, 73.6, 73.1, 72.5, 65.5, 64.8, 55.2, 35.7, 33.2, 25.9, 25.6, 23.0, 18.1, -4.5, -4.9; FAB-MS $e / v 753(\mathrm{M}+\mathrm{Na})^{+}$. Satisfactory high-resolution mass data could not be obtained; copies of the ${ }^{1} \mathrm{H}$ and ${ }^{13} \mathrm{C}$ NMR spectra are provided. 


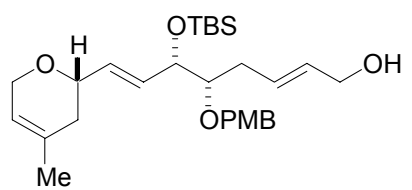

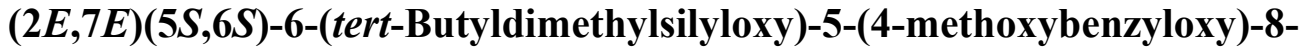
((2S)-4-methyl-3,6-dihydro-2H-pyran-2-yl)-octa-2,7-dien-1-ol: To a $0{ }^{\circ} \mathrm{C}$ solution of $0.440 \mathrm{~g}$ of the silyl ether (prepared above; $0.61 \mathrm{mmol}$ ) in $28 \mathrm{~mL}$ of nitromethane was slowly added $3.9 \mathrm{~mL}$ of formic acid dropwise. The resulting yellow solution was stirred for 20 min whereupon $40 \mathrm{~mL}$ of ice-cold saturated $\mathrm{NaHCO}_{3}$ and $30 \mathrm{~mL}$ of EtOAc were added. The layers were separated and the aqueous portion was extracted with EtOAc $(3 \times 40 \mathrm{~mL})$. The combined organics were washed with brine $(40 \mathrm{~mL})$, dried over $\mathrm{MgSO}_{4}$, filtered, and concentrated. The crude product was purified by flash chromatography $(35 \%$ EtOAc/Hex) to afford $0.250 \mathrm{~g}(86 \%)$ of the title allylic alcohol as a yellow oil. $[\alpha]_{\mathrm{D}}=-83(c 4.0$, $\mathrm{CHCl}_{3}$ ); IR (thin film): 3442, 2999, 2929, 2856, 1513, 1249, 1098, 1037, 972, 836, $777 \mathrm{~cm}^{-1}$; ${ }^{1} \mathrm{H}$ NMR $\left(300 \mathrm{MHz}, \mathrm{CDCl}_{3}\right): \delta 7.34(\mathrm{~d}, J=8.4 \mathrm{~Hz}, 2 \mathrm{H}), 6.95(\mathrm{~d}, J=8.5 \mathrm{~Hz}, 2 \mathrm{H}), 5.87(\mathrm{~m}, 2 \mathrm{H}), 5.72(\mathrm{~m}, 2 \mathrm{H})$, $5.50(\mathrm{~s}, 1 \mathrm{H}), 4.62(\mathrm{dd}, J=11.5,29.6 \mathrm{~Hz}, 2 \mathrm{H}), 4.37(\mathrm{dd}, J=4.5,4.5 \mathrm{~Hz}, 1 \mathrm{H}), 4.26(\mathrm{~s}, 2 \mathrm{H}), 4.13(\mathrm{~s}, 3 \mathrm{H})$, $3.89(\mathrm{~s}, 3 \mathrm{H}), 3.44(\mathrm{~m}, 1 \mathrm{H}), 2.37(\mathrm{~m}, 1 \mathrm{H}), 2.16-2.11(\mathrm{~m}, 2 \mathrm{H}), 1.79(\mathrm{~m}, 1 \mathrm{H}), 0.98(\mathrm{~s}, 9 \mathrm{H}), 0.11(\mathrm{~s}, 6 \mathrm{H})$; ${ }^{13} \mathrm{C}$ NMR $\left(75 \mathrm{MHz}, \mathrm{CDCl}_{3}\right): \delta 159.2,131.5,131.4,130.9,130.8,130.2,130.1,129.5,119.7,113.6$, $81.8, \quad 73.5, \quad 73.1, \quad 72.3, \quad 65.6, \quad 63.8, \quad 55.3, \quad 35.7, \quad 32.8, \quad 25.9, \quad 23.0, \quad 18.1$, $-4.5,-4.9$; HRMS calcd for $\mathrm{C}_{24} \mathrm{H}_{35} \mathrm{O}_{5} \mathrm{Si}\left[\mathrm{M}-{ }^{t} \mathrm{Bu}\right]^{+}:$431.2253, found 431.2275.

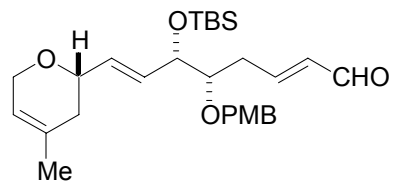

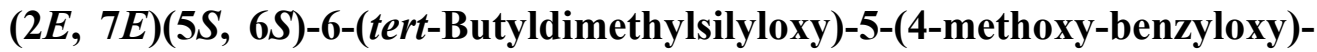
8-((2S)-4-methyl-3,6-dihydro-2H-pyran-2-yl)-octa-2,7-dienal (3): To a 25 ${ }^{\circ} \mathrm{C}$ solution of $0.117 \mathrm{~g}$ of the allylic alcohol (prepared above; $0.16 \mathrm{mmol}$ ) in $10 \mathrm{~mL}$ of $\mathrm{CH}_{2} \mathrm{Cl}_{2}$ was added $0.139 \mathrm{~g}$ of Dess-Martin periodinance $(0.33$ mmol) portionwise. The resulting turbid mixture was stirred $30 \mathrm{~min}$ then $8 \mathrm{~mL}$ of saturated $\mathrm{NaHCO}_{3}$ solution was added. The mixture was extracted with $\mathrm{CH}_{2} \mathrm{Cl}_{2}(3 \times 15 \mathrm{~mL})$ and the combined organics were washed with brine $(15 \mathrm{~mL})$, dried over $\mathrm{MgSO}_{4}$, filtered, and concentrated. The crude product was purified by flash chromatography (15\% EtOAc/hexanes) to afford $0.117 \mathrm{~g}(100 \%)$ of 3 as a pale yellow oil. $[\alpha]_{\mathrm{D}}=-86$ (c 3.9, $\mathrm{CHCl}_{3}$ ); IR (thin film): 2955, 2930, 2887, 2856, 1692, 1513, 1250, 1111 , 1036, 837, $778 \mathrm{~cm}^{-1} ;{ }^{1} \mathrm{H}$ NMR $\left(300 \mathrm{MHz}, \mathrm{CDCl}_{3}\right): \delta 9.55(\mathrm{~d}, J=7.9 \mathrm{~Hz}, 1 \mathrm{H}), 7.39(\mathrm{~d}, J=8.7 \mathrm{~Hz}, 2 \mathrm{H})$, $7.02(\mathrm{~d}, J=6.2 \mathrm{~Hz}, 2 \mathrm{H}), 6.89(\mathrm{ddd}, J=7.3,7.3,15.6 \mathrm{~Hz}, 1 \mathrm{H}), 6.22(\mathrm{dd}, J=7.9,15.6 \mathrm{~Hz}, 1 \mathrm{H}), 5.96$ (t, $J=3.0 \mathrm{~Hz}, 2 \mathrm{H}), 5.56(\mathrm{~s}, 1 \mathrm{H}), 4.75(\mathrm{~d}, J=11.5 \mathrm{~Hz}, 1 \mathrm{H}), 4.61(\mathrm{~d}, J=11.5 \mathrm{~Hz}, 1 \mathrm{H}), 4.32(\mathrm{~m}, 1 \mathrm{H}), 4.19$ $(\mathrm{m}, 1 \mathrm{H}), 3.95(\mathrm{~s}, 3 \mathrm{H}), 3.26(\mathrm{~m}, 1 \mathrm{H}), 2.68$ (dddd, $J=0.5,4.5,7.5,16.5 \mathrm{~Hz}, 1 \mathrm{H}), 2.48$ (dddd, $J=0.5$, 3.0, 4.0, 16.5 Hz, 1H), $2.19(\mathrm{~m}, 1 \mathrm{H}), 2.04(\mathrm{~m}, 1 \mathrm{H}), 1.84$ (br s, 3H), $1.04(\mathrm{~s}, 9 \mathrm{H}), 0.19(\mathrm{~s}, 6 \mathrm{H}) ;{ }^{13} \mathrm{C} \mathrm{NMR}$ $\left(75 \mathrm{MHz}, \mathrm{CDCl}_{3}\right): \delta 194.0,159.4,156.6,134.1,132.2,131.3,130.0,129.7,129.0,119.7,113.8,80.5$, 73.3, 72.4, 65.6, 55.3, 35.7, 33.4, 25.8, 22.9, 18.1, -4.6, -5.0; HRMS calcd for $\mathrm{C}_{24} \mathrm{H}_{33} \mathrm{O}_{5} \mathrm{Si}\left[\mathrm{M}-{ }^{t} \mathrm{Bu}\right]^{+}$: 429.2097, found 429.2077.

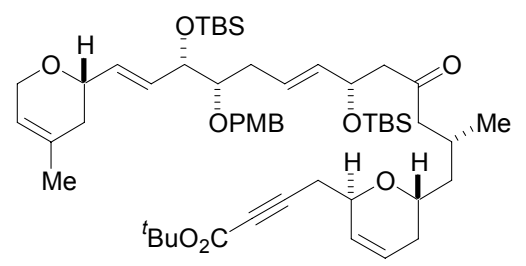

$4-\{(2 R, 6 R)-6-[(7 E, 12 E)(2 R, 6 S, 10 S, 11 S)-6,11-B i s-(t e r t-b u t y l-$ dimethylsilyloxy)-10-(4-methoxybenzyloxy)-2-methyl-13-((2S)-4methyl-3,6-dihydro-2H-pyran-2-yl)-4-oxotrideca-7,12-dienyl]-5,6dihydro-2H-pyran-2-yl\}-but-2-ynoic acid, tert-butyl ester: To a 0 ${ }^{\circ} \mathrm{C}$ suspension of $0.800 \mathrm{~g}$ of $(1 R, 2 R)-N, N^{\prime}$-Bis(paranitrobenzenesulfonyl)-1,2-diphenylethylenediamine $(1.4 \mathrm{mmol})$ in $71 \mathrm{~mL}$ of 1,2-dichloroethane was slowly added $2.75 \mathrm{~mL}$ of a $1.0 \mathrm{M} \mathrm{CH}_{2} \mathrm{Cl}_{2}$ solution of boron tribromide $(2.8 \mathrm{mmol})$ dropwise. After $5 \mathrm{~min}$, the reaction mixture was warmed to $50{ }^{\circ} \mathrm{C}$ and maintained for $8 \mathrm{~h}$. The solvent was evaporated under reduced pressure and the yellow residue was dissolved in $50 \mathrm{~mL}$ to toluene whereupon the solvent was again evaporated; the process of dissolution 
and subsequent evaporation was repeated two more times until the bromo borane reagent $\mathbf{2 6}$ was obtained as a white powder.

To a $-78{ }^{\circ} \mathrm{C}$ solution of $0.117 \mathrm{~g}$ of the boron reagent $26(0.17 \mathrm{mmol})$ in $4 \mathrm{~mL}$ of $\mathrm{CH}_{2} \mathrm{Cl}_{2}$ was slowlyadded $0.056 \mathrm{~g}$ of $2(0.17 \mathrm{mmol})$ as a solution in $0.5 \mathrm{~mL}$ of $\mathrm{CH}_{2} \mathrm{Cl}_{2}$. After stirring the resulting colorless solution for $2 \mathrm{~h}$, a solution of $0.072 \mathrm{~g}$ of $3(0.15 \mathrm{mmol})$ in $0.5 \mathrm{~mL}$ of $\mathrm{CH}_{2} \mathrm{Cl}_{2} \mathrm{Was}$ added dropwise. After stirring $1 \mathrm{~h}$ at $-78{ }^{\circ} \mathrm{C}, 1 \mathrm{~mL}$ of $\mathrm{MeOH}$ and $5 \mathrm{~mL}$ of phosphate buffer (pH 7) were added sequentially. The reaction mixture was allowed to warm to ambient temperature and stirred for $30 \mathrm{~min}$. The layers were separated and the aqueous portion was extracted with $\mathrm{CH}_{2} \mathrm{Cl}_{2}(3 \times 9 \mathrm{~mL})$. The combined organics were dried over $\mathrm{MgSO}_{4}$, filtered, and concentrated to provide the crude product mixture containing 27.

To a $0{ }^{\circ} \mathrm{C}$ DMF solution $(4 \mathrm{~mL})$ of the resulting yellow residue $(27)$ and $0.059 \mathrm{~g}$ of imidazole $(1.1$ mmol) was added $0.126 \mathrm{~g}$ of $\mathrm{TBSCl}(1.0 \mathrm{mmol})$. The reaction was warmed to ambient temperature and stirred $7 \mathrm{~h}$ whereupon $10 \mathrm{~mL}$ of saturated $\mathrm{NaHCO}_{3}$ and $20 \mathrm{~mL}$ of $\mathrm{CH}_{2} \mathrm{Cl}_{2}$ were added. The layers weer separated with the aqueous layer being extracted with $\mathrm{CH}_{2} \mathrm{Cl}_{2}(3 \times 20 \mathrm{~mL})$. The combined organics were washed with brine $(20 \mathrm{~mL})$, dried over $\mathrm{MgSO}_{4}$, filtered, and concentrated. The crude product mixture was purified by flash chromatography(15\% EtOAc/Hex) to afford $0.141 \mathrm{~g}(89 \%)$ of the silyl-protected aldol adduct as a yellow oil. Separation of the $\mathrm{C}_{15}$ epimers by HPLC [Zorbax column, flow rate $0.3 \mathrm{~mL} / \mathrm{min}, 3.5 \%{ }^{i} \mathrm{PrOH}, 96.5 \%$ hexane, $\mathrm{T}_{\mathrm{r}}: 65.2(15 S), 67.8(15 R)$ ] provided the diastereomer ratio: $15 S: 15 R=9: 1 .[\alpha]_{\mathrm{D}}=-82\left(c 2.1, \mathrm{CHCl}_{3}\right)$; IR (thin film): 2955, 2929, 2856, 2239, 1708, 1253, 1704, 837, $777 \mathrm{~cm}^{-1}$; ${ }^{1} \mathrm{H}$ NMR (300 MHz, $\left.\mathrm{CDCl}_{3}\right): \delta 7.25(\mathrm{~d}, J=8.6 \mathrm{~Hz}, 2 \mathrm{H}), 6.86$ $(\mathrm{d}, J=8.6 \mathrm{~Hz}, 2 \mathrm{H}), 5.93-5.61(\mathrm{~m}, 5 \mathrm{H}), 5.48-5.41(\mathrm{~m}, 2 \mathrm{H}), 4.56-4.435(\mathrm{~m}, 3 \mathrm{H}), 4.39$ (br t, $1 \mathrm{H}), 4.27(\mathrm{t}$, $J=4.3,4.3 \mathrm{~Hz}, 1 \mathrm{H}), 4.17(\mathrm{~s}, 2 \mathrm{H}), 4.06-4.00(\mathrm{~m}, 1 \mathrm{H}), 3.79(\mathrm{~s}, 3 \mathrm{H}), 3.79-3.76(\mathrm{~m}, 1 \mathrm{H}), 3.30(\mathrm{~m}, 1 \mathrm{H})$, 2.63-2.55 (m, 3H), 2.38-2.28 (m, 6H), 2.03-1.92 (m, 6H), $1.70(\mathrm{~s}, 3 \mathrm{H}), 1.48(\mathrm{~s}, 9 \mathrm{H}), 0.93(\mathrm{~d}, J=6.1$ $\mathrm{Hz}, 3 \mathrm{H}), 0.88(\mathrm{~s}, 9 \mathrm{H}), 0.84(\mathrm{~s}, 9 \mathrm{H}), 0.01(\mathrm{~m}, 12 \mathrm{H}) ;{ }^{13} \mathrm{C} \mathrm{NMR}\left(75 \mathrm{MHz}, \mathrm{CDCl}_{3}\right): \delta 208.7,159.2,152.7$, 134.3, 131.6, 131.5, 130.9, 130.1, 129.5, 128.1, 127.5, 125.9, 119.8, 113.8, 83.2, 82.4, 76.2, 73.6, 72.8, $72.5,70.2,70.0,66.2,65.7,55.4,52.4,51.5,42.1,35.8,32.7,30.9,28.1,26.0,25.3,24.8,23.1,19.7$, 18.7, 18.3, 18.2, -4.1, -4.4, -4.8 (2C); HRMS calcd for $\mathrm{C}_{53} \mathrm{H}_{84} \mathrm{O}_{9} \mathrm{Si}_{2}[\mathrm{M}+\mathrm{Na}]^{+}:$943.5552, found 943.5579 .

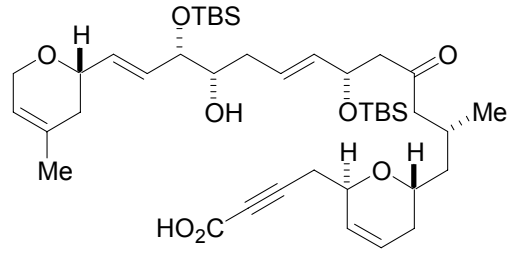

Acid alcohol 28: To a $25{ }^{\circ} \mathrm{C}$ solution of $0.063 \mathrm{~g}$ of the silyl-protected aldol adduct (prepared above; 0.069 mmol) in $12 \mathrm{~mL}$ of $\mathrm{CH}_{2} \mathrm{Cl}_{2}$ and $6 \mathrm{~mL}$ of phosphate buffer $(\mathrm{pH}=7)$ was added $0.134 \mathrm{~g}$ of DDQ $(0.48 \mathrm{mmol})$ portionwise. After stirring $4 \mathrm{~h}$, the reaction was diluted with $\mathrm{CH}_{2} \mathrm{Cl}_{2}(20 \mathrm{~mL})$. The separated organic layer was washed with saturated $\mathrm{NaHCO}_{3}(2 \times 15 \mathrm{~mL})$ until it was colorless. The combined organic extracts were dried, filtered, and concentrated to give a yellow oil that was dissolved in $8 \mathrm{~mL}$ of $\mathrm{CH}_{2} \mathrm{Cl}_{2}$. To the resulting yellow solution was cooled to $-50{ }^{\circ} \mathrm{C}$ and 0.34 $\mathrm{mL}$ of 2,6-di-tert-butylpyrridine $(1.4 \mathrm{mmol})$ and $0.15 \mathrm{~mL}$ of trimethylsilyl trifluoromethanesulfonate $(0.7 \mathrm{mmol})$ were added sequentially. The reaction mixture was warmed to $0{ }^{\circ} \mathrm{C}$ and stirred $2.5 \mathrm{~h}$ whereupon $2.0 \mathrm{~mL}$ of buffer solution $(\mathrm{pH}=5)$ was added at $0{ }^{\circ} \mathrm{C}$ and the reaction was stirred vigorously for another $1 \mathrm{~h}$. The separated aqueous layer was extracted with $\mathrm{CH}_{2} \mathrm{Cl}_{2}(3 \times 30 \mathrm{~mL})$ and the combined organics were washed with brine $(30 \mathrm{~mL})$, dried over $\mathrm{MgSO}_{4}$, filtered, and concentrated. The crude product mixture was purified by flash chromatography $(20 \% \mathrm{EtOAc} / \mathrm{Hex}$ to $15 \%$ EtOH/EtOAc) to afford $0.050 \mathrm{~g}(94 \%)$ of 28 as a yellow oil. $[\alpha]_{\mathrm{D}}=-70\left(c 2.5, \mathrm{CHCl}_{3}\right)$; IR (thin film): $3395,3035,2953,2929,2852,2237,1713,1470,1359,1252,1091,837,778 \mathrm{~cm}^{-1} ;{ }^{1} \mathrm{H}$ NMR (300 
$\left.\mathrm{MHz}, \mathrm{CDCl}_{3}\right): \delta 5.95-5.85(\mathrm{~m}, 1 \mathrm{H}), 5.80-5.46(\mathrm{~m}, 5 \mathrm{H}), 5.42($ br s, $1 \mathrm{H}), 4.62(\mathrm{~m}, 1 \mathrm{H}), 4.42(\mathrm{~m}, 1 \mathrm{H})$, 4.19 (brs, 2H), 4.13-3.95 (m, 3H), $3.74(\mathrm{~m}, 1 \mathrm{H}), 3.55(\mathrm{~m}, 1 \mathrm{H}), 2.80-2.55(\mathrm{~m}, 2 \mathrm{H}), 2.54-2.37(\mathrm{~m}, 2 \mathrm{H})$, 2.35-2.20 (m, 2H), 2.13-1.88 (m, 6H), $1.71(\mathrm{~s}, 3 \mathrm{H}), 1.65-1.50(\mathrm{~m}, 1 \mathrm{H}), 1.36-1.20(\mathrm{~m}, 2 \mathrm{H}), 0.95(\mathrm{~d}, \mathrm{~J}=$ $5.7 \mathrm{~Hz}, 3 \mathrm{H}), 0.90(\mathrm{~s}, 9 \mathrm{H}), 0.86(\mathrm{~s}, 9 \mathrm{H}), 0.12(\mathrm{~s}, 3 \mathrm{H}), 0.08(\mathrm{~s}, 3 \mathrm{H}), 0.04$ (brs, 6H); ${ }^{13} \mathrm{C} \mathrm{NMR}(75 \mathrm{MHz}$, $\left.\mathrm{CDCl}_{3}\right)$ : $\delta 209.5,154.8,135.3,134.3,133.6,131.2,130.5,127.4,126.3,125.6,119.5,86.3,75.7,74.5$, $73.4,70.4,69.4,66.0,65.4,52.3,50.3,42.3,35.4,35.1,31.0,25.9,24.3,22.9,20.0,18.1,0.44,-3.9,-$ 4.3, -4.8, -5.0; HRMS calcd for $\mathrm{C}_{41} \mathrm{H}_{68} \mathrm{O}_{8} \mathrm{Si}_{2}[\mathrm{M}+\mathrm{Na}]^{+}:$767.4370, found 767.4345.

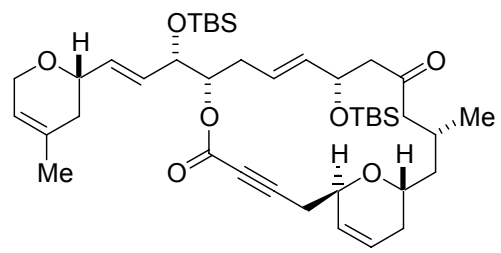

Lactone 29: To a $0{ }^{\circ} \mathrm{C}$ solution of $0.0228 \mathrm{~g}$ of 4-pyrrolidinopyridine $(0.15 \mathrm{mmol})$ and $0.050 \mathrm{~mL}$ of ${ }^{i} \operatorname{Pr}_{2} \mathrm{NEt}(0.30 \mathrm{mmol})$ in $5.8 \mathrm{~mL}$ of toluene was slowly added $0.024 \mathrm{~mL}$ of 2,4,6-trichlorobenzoyl chloride (0.15 mmol) dropwise. The resulting pale yellow suspension was stirred for $15 \mathrm{~min}$ at $0{ }^{\circ} \mathrm{C}$ whereupon a solution of $0.0056 \mathrm{~g}$ of $\mathbf{2 8}$ $(0.077 \mathrm{mmol})$ in $2.4 \mathrm{~mL}$ of toluene was added over $2 \mathrm{~h}$ at $0{ }^{\circ} \mathrm{C}$. The resulting pale yellow suspension was stirred for $16 \mathrm{~h}$ at $0{ }^{\circ} \mathrm{C}$. The reaction was quenched by adding $5 \mathrm{~mL}$ of brine and the separated aqueous layer was extracted with $\mathrm{Et}_{2} \mathrm{O}(3 \times 10 \mathrm{~mL})$. The combined organics were washed with brine $(10 \mathrm{~mL})$, dried over $\mathrm{MgSO}_{4}$, filtered, and concentrated. The crude product mixture was purified by flash chromatography $(15 \%$ EtOAc/Hex $)$ to afford $0.0051 \mathrm{~g}(93 \%)$ of 29 as a yellow oil. $[\alpha]_{\mathrm{D}}=-67(c$ 2.2, $\mathrm{CHCl}_{3}$ ); IR (thin film): 3033, 2956, 2929, 2856, 2237, 1713, 1471, 1361, 1250, 1094, 1067, 964, $837 \mathrm{~cm}^{-1} ;{ }^{1} \mathrm{H}$ NMR $\left(300 \mathrm{MHz}, \mathrm{CDCl}_{3}\right): \delta 5.91-5.79(\mathrm{~m}, 2 \mathrm{H}), 5.70(\mathrm{dd}, J=6.0,15.6 \mathrm{~Hz}, 1 \mathrm{H}), 5.65-5.51$ (m, 3H), 5.43 (br s, 1H), 4.95 (ddd, $J=2.4,6.8,9.3 \mathrm{~Hz}, 1 \mathrm{H}), 4.66$ (br d, $J=9.0 \mathrm{~Hz}, 1 \mathrm{H}), 4.43$ (br d, $J$ $=9.0 \mathrm{~Hz}, 1 \mathrm{H}), 4.20-4.16(\mathrm{~m}, 3 \mathrm{H}), 4.07(\mathrm{ddd}, J=3.0,3.0,9.1 \mathrm{~Hz}, 1 \mathrm{H}), 3.61-3.53(\mathrm{~m}, 1 \mathrm{H}), 2.67(\mathrm{dd}, J=$ $11.1,17.6 \mathrm{~Hz}, 2 \mathrm{H}), 2.45-2.25(\mathrm{~m}, 5 \mathrm{H}), 2.20-2.02(\mathrm{~m}, 4 \mathrm{H}), 1.72(\mathrm{~s}, 3 \mathrm{H}), 1.95-1.89(\mathrm{~m}, 2 \mathrm{H}), 1.39$ (dd, $J$ $=10.1,12.5 \mathrm{~Hz}, 1 \mathrm{H}), 1.14(\mathrm{dd}, J=7.6,13.5 \mathrm{~Hz}, 1 \mathrm{H}), 1.01(\mathrm{~d}, J=6.2 \mathrm{~Hz}, 3 \mathrm{H}), 0.89$ (s, 9H), $0.85(\mathrm{~s}$, 9H), $0.10(\mathrm{~s}, 3 \mathrm{H}), 0.06(\mathrm{~s}, 3 \mathrm{H}), 0.00(\mathrm{~s}, 6 \mathrm{H}) ;{ }^{13} \mathrm{C} \mathrm{NMR}\left(75 \mathrm{MHz}, \mathrm{CDCl}_{3}\right): \delta 209.9,153.2,137.1,133.6$, $131.3,128.9,127.5,126.7,123.6,119.8,86.7,73.8,73.6,73.2,71.4,68.4,65.9,65.5,54.1,49.8,41.8$, 35.7, 31.6, 26.8, 25.9, 25.8, 23.9, 22.9, 22.6, 21.4, 18.1, 18.0, 14.1, -4.4, -4.4, -4.9, -5.2; ESI-MS: $749.3\left(\mathrm{M}^{+} \mathrm{Na}\right)^{+}$; HRMS calcd for $\mathrm{C}_{41} \mathrm{H}_{66} \mathrm{O}_{7} \mathrm{Si}_{2}[\mathrm{M}+\mathrm{Na}]^{+}:$749.4245, found 749.4279 .

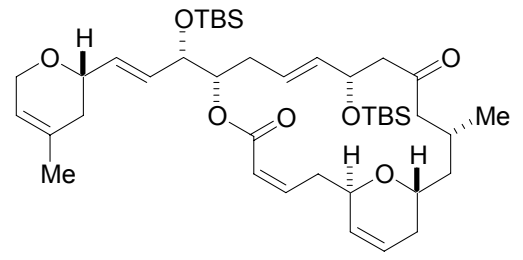

Keto lactone 30: To a solution of $8.5 \mathrm{mg}$ of $29(11.7 \mu \mathrm{mol})$ in $3 \mathrm{~mL}$ of EtOAc and $3 \mathrm{~mL}$ of 1-hexene containing $0.014 \mathrm{~mL}$ of quinoline was added $15 \mathrm{mg}$ of Lindlar's catalyst ( $5 \% \mathrm{Pd}$ by wt.). The resulting black suspension was subjected to 1 atmosphere $\mathrm{H}_{2}$ (ballon) (CAUTION: Dihydrogen gas is extremely flammable.) and stirred $1 \mathrm{~h}$ at ambient temperature. The reaction flask was then purged with $\mathrm{N}_{2}$ and the reaction mixture was filtered through Celite and the filtrate was concentrated. The crude product mixture was purified by flash chromatography (2\% EtOAc/hexanes) to afford $7.5 \mathrm{mg}$ (88\%) of $\mathbf{3 0}$ as a clear, colorless oil. $[\alpha]_{\mathrm{D}}=-155\left(c\right.$ 1.2, $\left.\mathrm{CHCl}_{3}\right)$; IR (thin film): 2955, 2927, 2855, 1720, 1651, 1419, $1111,837 \mathrm{~cm}^{-1} ;{ }^{1} \mathrm{H}$ NMR $\left(300 \mathrm{MHz}, \mathrm{CDCl}_{3}\right): \delta 6.35(\mathrm{ddd}, J=4.1,9.6,11.4 \mathrm{~Hz}, 1 \mathrm{H}), 5.90-5.77(\mathrm{~m}$, $3 \mathrm{H}), 5.73-5.49$ (m, $4 \mathrm{H}), 5.43$ (br s, $1 \mathrm{H}), 4.86$ (ddd, $J=2.1,6.0,11.1 \mathrm{~Hz}, 1 \mathrm{H}), 4.59$ (ddd, $J=6.0,6.0$, $6.0 \mathrm{~Hz}, 1 \mathrm{H}), 4.31$,(br d, $J=9.8 \mathrm{~Hz}, 1 \mathrm{H}), 4.23-4.19$ (m, 3H), 4.06 (ddd, $J=4.4,9.3 \mathrm{~Hz}, 1 \mathrm{H}), 3.79-3.65$ $(\mathrm{m}, 2 \mathrm{H}), 2.61(\mathrm{dd}, J=6.2,16.2 \mathrm{~Hz}, 1 \mathrm{H}), 2.46(\mathrm{dd}, J=6.6,16.3 \mathrm{~Hz}, 1 \mathrm{H}), 2.41-2.31(\mathrm{~m}, 2 \mathrm{H}), 2.25$ (dddd, $J=2.6,2.6,2.6,16.6 \mathrm{~Hz}, 1 \mathrm{H}), 2.16-2.01(\mathrm{~m}, 5 \mathrm{H}), 1.95-1.85(\mathrm{~m}, 2 \mathrm{H}), 1.72(\mathrm{~s}, 3 \mathrm{H}), 1.51$ (dddd, $J$ $=7.7,7.7,7.7,7.7 \mathrm{~Hz}, 1 \mathrm{H}), 1.27(\mathrm{ddd}, J=3.6,6.1,9.9 \mathrm{~Hz}, 1 \mathrm{H}), 0.91(\mathrm{~d}, J=6.4 \mathrm{~Hz}, 3 \mathrm{H}), 0.89$ (s, 9H), $0.87(\mathrm{~s}, 9 \mathrm{H}), 0.07(\mathrm{~s}, 3 \mathrm{H}), 0.05(\mathrm{~s}, 3 \mathrm{H}), 0.02(\mathrm{~s}, 3 \mathrm{H}), 0.01(\mathrm{~s}, 3 \mathrm{H}) ;{ }^{13} \mathrm{C} \mathrm{NMR}\left(75 \mathrm{MHz}, \mathrm{CDCl}_{3}\right): \delta$ 209.2, 165.3, 148.4, 135.8, 132.9, 131.3, 129.0, 128.8, 125.7, 124.9, 121.4, 119.8, 75.1, 73.3, 73.2, 
73.0, 68.6, 66.9, 65.5, 51.8, 51.3, 42.5, 35.7, 33.6, 31.6, 31.3, 28.7, 25.8, 25.7, 22.9, 21.0, 18.1, 18.0, $4.5(2 \mathrm{C}),-4.9,-5.0$; HRMS calcd for $\mathrm{C}_{41} \mathrm{H}_{68} \mathrm{O}_{7} \mathrm{Si}_{2}[\mathrm{M}+\mathrm{K}]^{+}:$767.4141, found 767.4158.

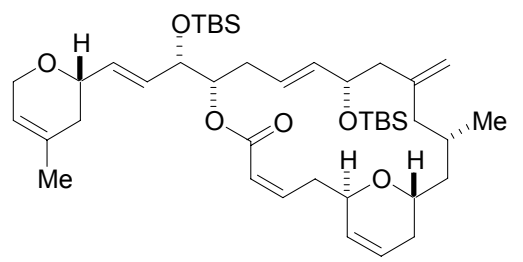

Protected desepoxylaulimalide 31: To a suspension of $0.365 \mathrm{~g}$ of zinc $(5.58 \mathrm{mmol})$ and $0.025 \mathrm{~g}$ of lead (II) iodide $(0.054 \mathrm{mmol})$ in THF $(5 \mathrm{~mL})$ was added $0.250 \mathrm{~mL}$ of $\mathrm{CH}_{2} \mathrm{I}_{2}(3.10 \mathrm{mmol})$. The resulting pale yellow suspension was maintained for $30 \mathrm{~min}$ at ambient temperature then cooled to $0{ }^{\circ} \mathrm{C}$. To the $0{ }^{\circ} \mathrm{C}$ suspension was added $0.25 \mathrm{~mL}$ of a $1.0 \mathrm{M}$ solution of $\mathrm{TiCl}_{4}$ in $\mathrm{CH}_{2} \mathrm{Cl}_{2}(0.25 \mathrm{mmol})$ and the resulting dark brown suspension was warmed to ambient temperature and maintained for an additional $30 \mathrm{~min}$. The resulting brown suspension was drawn into a syringe and added in portions to a $0{ }^{\circ} \mathrm{C}$ solution of 10.8 $\mathrm{mg}$ of $30(14.8 \mu \mathrm{mol})$ in THF $(1 \mathrm{~mL})$; the reaction was monitored by TLC immediately after each portionwise addition and addition was continued until the starting ketone was completely consumed. A 1:1 mixture of saturated aqueous $\mathrm{NaHCO}_{3}$ and brine was added to the reaction mixture and the resulting mixture was diluted with $\mathrm{Et}_{2} \mathrm{O}$. The aqueous and organic layers were separated with the aqueous portion being extracted with $\mathrm{Et}_{2} \mathrm{O}(3 \times 10 \mathrm{~mL})$. The combined organics were washed with brine, dried over $\mathrm{NaSO}_{4}$, filtered, and concentrated. Purifying the crude product mixture by flash chromatography $\left(5 \%\right.$ EtOAc/hexanes) afforded $9.1 \mathrm{mg}(85 \%)$ of 31 as a clear, colorless oil. $[\alpha]_{\mathrm{D}}=-$ 118 (c 1.4, $\mathrm{CHCl}_{3}$ ); IR (thin film): 2955, 2928, 2856, 1723, 1074, 836, $776 \mathrm{~cm}^{-1}$; ${ }^{1} \mathrm{H} \mathrm{NMR}(300 \mathrm{MHz}$, $\left.\mathrm{CDCl}_{3}\right): \delta 6.32(\mathrm{ddd}, J=4.8,9.8,10.2 \mathrm{~Hz}, 1 \mathrm{H}), 5.91-5.82(\mathrm{~m}, 2 \mathrm{H}), 5.80-5.67(\mathrm{~m}, 3 \mathrm{H}), 5.53-5.49(\mathrm{~m}$, 2H), 5.43 (br s, 1H), 4.89 (ddd, $J=2.4,6.1,10.4 \mathrm{~Hz}, 1 \mathrm{H}), 4.77$ (br s, 1H), 4.75 (br s, 1H), 4.30-4.15 $(\mathrm{m}, 5 \mathrm{H}), 4.06(\mathrm{ddd}, J=4.3,4.3,9.2 \mathrm{~Hz}, 1 \mathrm{H}), 3.80(\mathrm{~m}, 1 \mathrm{H}), 3.68(\mathrm{ddd}, J=10.0,10.0,15.2 \mathrm{~Hz}, 1 \mathrm{H})$, 2.37-2.22 (m, 3H), 2.19-2.02 (m, 6H), 1.94-1.82 (m, 3H), $1.71(\mathrm{~s}, 3 \mathrm{H}), 1.62-1.54(\mathrm{~m}, 1 \mathrm{H}), 1.17$ (ddd, $J$ $=4.9,6.8,12.0 \mathrm{~Hz}, 1 \mathrm{H}), 0.88(\mathrm{br} \mathrm{s}, 21 \mathrm{H}), 0.07(\mathrm{~s}, 3 \mathrm{H}), 0.04(\mathrm{~s}, 3 \mathrm{H}), 0.02(\mathrm{~s}, 3 \mathrm{H}), 0.01(\mathrm{~s}, 3 \mathrm{H}) ;{ }^{13} \mathrm{C}$ NMR (75 MHz, $\left.\mathrm{CDCl}_{3}\right): \delta 165.3,147.0,144.7,136.3,132.8,131.3,129.0,128.6,125.3,124.9,121.6$, $119.7,113.4,75.6,73.3,73.1,72.2,72.1,67.0,65.5,45.0,44.7,43.1,35.7,33.8,31.6,31.4,28.8,25.9$, 25.7, 22.9, 20.3, 18.2, 18.0, -4.3, -4.5, -4.8, -4.9; HRMS calcd for $\mathrm{C}_{42} \mathrm{H}_{70} \mathrm{O}_{6} \mathrm{Si}_{2}[\mathrm{M}+\mathrm{Na}]^{+}:$749.4609, found 749.4586 .

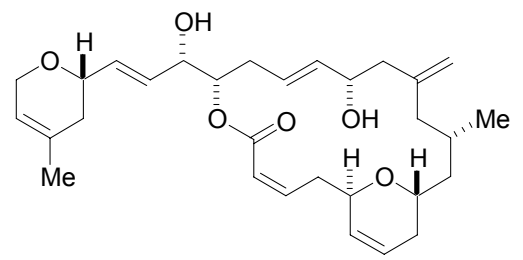

Desepoxylaulimalide: To a $0{ }^{\circ} \mathrm{C}$ solution of $13 \mathrm{mg}$ of silyl ether $\mathbf{3 1}$ $(17.9 \mu \mathrm{mol})$ in THF $(2 \mathrm{~mL})$ was added $1.0 \mathrm{~mL}$ of HF.pyridine complex dropwise via syringe. The reaction was maintained for $1 \mathrm{~h}$ at ambient temperature, then poured into a $0{ }^{\circ} \mathrm{C}$ mixture of saturated aqueous $\mathrm{NaHCO}_{3}(50 \mathrm{~mL})$ and EtOAc $(30 \mathrm{~mL})$. The layers were separated and the aqueous portion was extracted with EtOAc $(3 \times 20 \mathrm{~mL})$. The combined organics were washed with brine, dried over $\mathrm{NaSO}_{4}$, filtered, and concentrated. The crude product was purified by flash chromatography (40\% EtOAc/hexanes) to obtain $8.0 \mathrm{mg}(90 \%)$ of desepoxy-laulimalide as a pale yellow oil. $[\alpha]_{\mathrm{D}}=-171\left(c 0.7, \mathrm{CHCl}_{3}\right)$; IR (thin film): 3415, 2924, 2853, 1720, 1415, $1165 \mathrm{~cm}^{-1}$; ${ }^{1} \mathrm{H}$ NMR $\left(300 \mathrm{MHz}, \mathrm{CDCl}_{3}\right) \delta 6.36(\mathrm{ddd}, J=5.3,9.9,11.4 \mathrm{~Hz}, 1 \mathrm{H})$, 5.94-5.82 (m, 3H), 5.79-5.69 (m, 2H), 5.64-5.61 (m, 2H), 5.42 (brs, 1H), $5.00($ app q, $J=6.6 \mathrm{~Hz}, 1 \mathrm{H})$, 4.87 (br s, 2H), 4.23-4.12 (m, 5H), 4.05 (ddd, $J=4.4,4.4,9.1 \mathrm{~Hz}, 1 \mathrm{H}), 3.92-3.84(\mathrm{~m}, 1 \mathrm{H}), 3.56$ (dddd, $J=1.3,8.0,9.9,18 \mathrm{~Hz}, 1 \mathrm{H}), 2.39-2.32(\mathrm{~m}, 2 \mathrm{H}), 2.31-2.22(\mathrm{~m}, 2 \mathrm{H}), 2.20-2.08(\mathrm{~m}, 3 \mathrm{H}), 2.07-1.97$ (m, $1 \mathrm{H}), 1.96-1.84(\mathrm{~m}, 3 \mathrm{H}), 1.83-1.74(\mathrm{~m}, 3 \mathrm{H}), 1.70(\mathrm{~s}, 3 \mathrm{H}), 1.67-1.61(\mathrm{~m}, 1 \mathrm{H}), 1.14(\mathrm{ddd}, J=4.0,7.5$, $11.7 \mathrm{~Hz}, 1 \mathrm{H}), 0.87(\mathrm{~d}, J=6.0 \mathrm{~Hz}, 3 \mathrm{H}) ;{ }^{13} \mathrm{C} \mathrm{NMR}\left(75 \mathrm{MHz}, \mathrm{CDCl}_{3}\right): \delta 165.6,147.3,144.9,135.4$, $133.9,131.3,129.0,128.3,126.5,124.8,121.2,119.7,114.3,75.3,73.7,73.1,71.3,69.8,67.6,65.6$, 
44.8, 43.3, 42.3, 35.7, 34.4, 33.6, 30.9, 28.3, 22.9, 19.7; HRMS calcd for $\mathrm{C}_{30} \mathrm{H}_{42} \mathrm{O}_{6}[\mathrm{M}+\mathrm{Na}]^{+}$: 512.2879 , found 521.2880 .

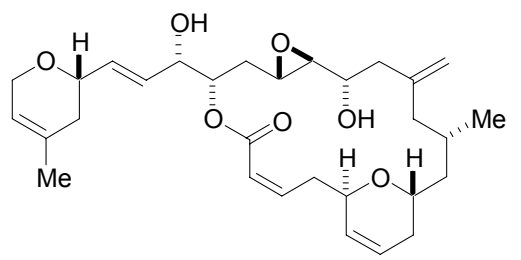

(-)-Laulimalide (1): To a $-20{ }^{\circ} \mathrm{C}$ suspension of $0.130 \mathrm{~g}$ of $4 \AA$ molecular sieves in $\mathrm{CH}_{2} \mathrm{Cl}_{2}(4 \mathrm{~mL})$ was added $5 \mu$ of $(+)$-DIPT $(22.5$ $\mu \mathrm{mol})$ followed by $5 \mu \mathrm{L}$ of titanium tetraisopropoxide $(16.1 \mu \mathrm{mol})$. The reaction mixture was maintained at $-20^{\circ} \mathrm{C}$ for 30 min then treated with $4 \mu \mathrm{L}$ of a $4.3 \mathrm{M}$ solution of ${ }^{t} \mathrm{BuOOH}$ in toluene (1 equiv, $16 \mu \mathrm{m}$ ).

The reaction was maintained for an additional $30 \mathrm{~min}$ at $-20{ }^{\circ} \mathrm{C}$ whereupon a solution of $8 \mathrm{mg}$ of desepoxy-laulimalide $(16 \mu \mathrm{m})$ in $\mathrm{CH}_{2} \mathrm{Cl}_{2}(2 \mathrm{~mL})$ was added dropwise via syringe and the reaction was stirred at $-20{ }^{\circ} \mathrm{C}$ for $2 \mathrm{~h}$. A mixture of $4 \mathrm{~N} \mathrm{NaOH}(0.5 \mathrm{~mL})$ and brine $(1.5 \mathrm{~mL})$ was added to the reaction mixture and the resulting mixture was warmed to $0{ }^{\circ} \mathrm{C}$ and stirred $90 \mathrm{~min}$. The mixture was extracted with $\mathrm{CH}_{2} \mathrm{Cl}_{2}(3 \times 10 \mathrm{~mL})$ and the combined organic layers were washed with brine and filtered through Celite. The filtrate was dried over $\mathrm{Na}_{2} \mathrm{SO}_{4}$, filtered and concentrated. The crude product was purified by flash chromatography ( $25 \%$ EtOAc/hexanes) to provide a pale yellow oil that was then triturated with $5 \%{ }^{i} \mathrm{PrOH} /$ hexanes to afford $5.5 \mathrm{mg}(69 \%)$ of (-)-laulimalide (1) as a white solid. $[\alpha]_{\mathrm{D}}=-198\left(c\right.$ 0.1, $\left.\mathrm{CHCl}_{3}\right)$; IR (thin film): 3423, 3071, 3032, 2917, 2846, 1719, 1642, 1422, $1383,1213,1169,894 \mathrm{~cm}^{-1}$; ${ }^{1} \mathrm{H}$ NMR $\left(600 \mathrm{MHz}, \mathrm{CDCl}_{3}\right): \delta 6.45(\mathrm{ddd}, J=3.8,10.1,11.4 \mathrm{~Hz}, 1 \mathrm{H})$, $5.94-5.83(\mathrm{~m}, 3 \mathrm{H}), 5.77$ (dd, $J=5.7,15.7 \mathrm{~Hz}, 1 \mathrm{H}), 5.72-5.69(\mathrm{~m}, 2 \mathrm{H}), 5.43$ (br s, $1 \mathrm{H}), 5.17$ (ddd, $J=$ 1.6, 5.2, $11.2 \mathrm{~Hz}, 1 \mathrm{H}), 4.88$ (br s, $1 \mathrm{H}), 4.86$ (br s, $1 \mathrm{H}$ ), 4.32 (br d, $J=9.4 \mathrm{~Hz}, 1 \mathrm{H}), 4.24$ (ddd, $J=5.5$, $5.5,5.5 \mathrm{~Hz}, 1 \mathrm{H}), 4.19(\mathrm{~m}, 2 \mathrm{H}), 4.07(\mathrm{~m}, 1 \mathrm{H}), 4.04(\mathrm{ddd}, J=4.5,4.5,9.7 \mathrm{~Hz}, 1 \mathrm{H}), 3.79-3.72(\mathrm{~m}, 2 \mathrm{H})$, 3.08 (ddd, $J=3.3,3.3,9.1 \mathrm{~Hz}, 1 \mathrm{H}$ ), 2.91 (ddd, $J=2.6,2.6,2.6 \mathrm{~Hz}, 1 \mathrm{H}), 2.40-2.37$ (m, 2H), 2.22 (dddd, $J=2.7,2.7,2.7,16.8 \mathrm{~Hz}, 1 \mathrm{H}), 2.13$ (brd, $J=15.3 \mathrm{~Hz}, 1 \mathrm{H}), 2.07-1.85(\mathrm{~m}, 7 \mathrm{H}), 1.79$ (dd, $J=$ $10.0,12.8 \mathrm{~Hz}, 1 \mathrm{H}), 1.70(\mathrm{br} \mathrm{s}, 3 \mathrm{H}), 1.54-1.43(\mathrm{~m}, 2 \mathrm{H}), 1.37-1.31(\mathrm{~m}, 1 \mathrm{H}), 0.84(\mathrm{~d}, J=6.5 \mathrm{~Hz}, 3 \mathrm{H}) ;{ }^{13} \mathrm{C}$ NMR $\left(125 \mathrm{MHz}, \mathrm{CDCl}_{3}\right): \delta 166.0,150.3,144.8,133.9,131.2,128.7,128.5,125.2,120.5,119.7$, $112.5,73.4,73.2,73.1,72.3,67.9,66.5,65.6,60.7,52.1,45.5,43.4,37.1,35.6,33.8,33.3,31.6,29.7$, 22.9, 20.7; HRMS calcd for $\mathrm{C}_{30} \mathrm{H}_{42} \mathrm{O}_{7}[\mathrm{M}+\mathrm{Na}]^{+}: 537.2828$, found 537.2816. 


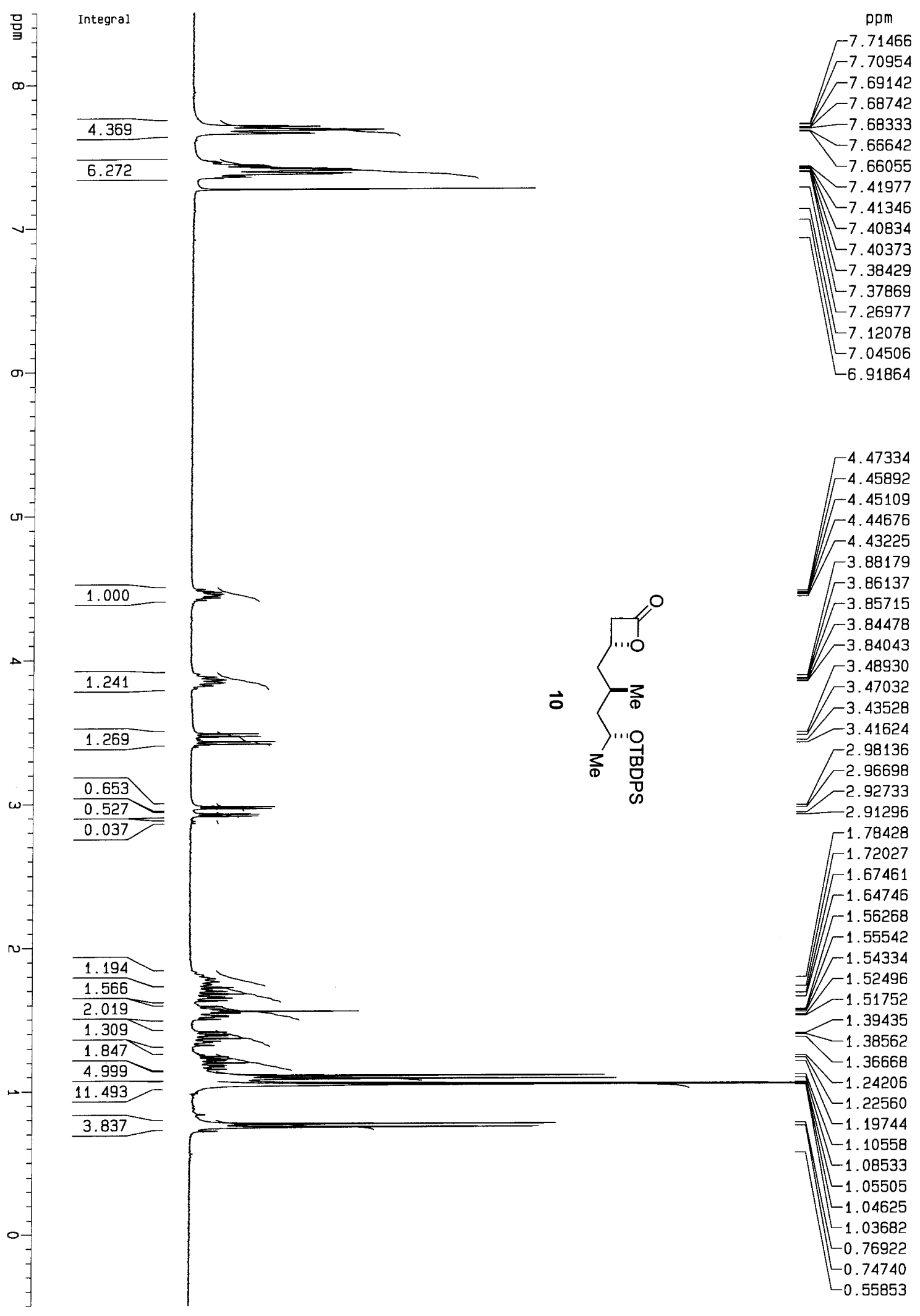




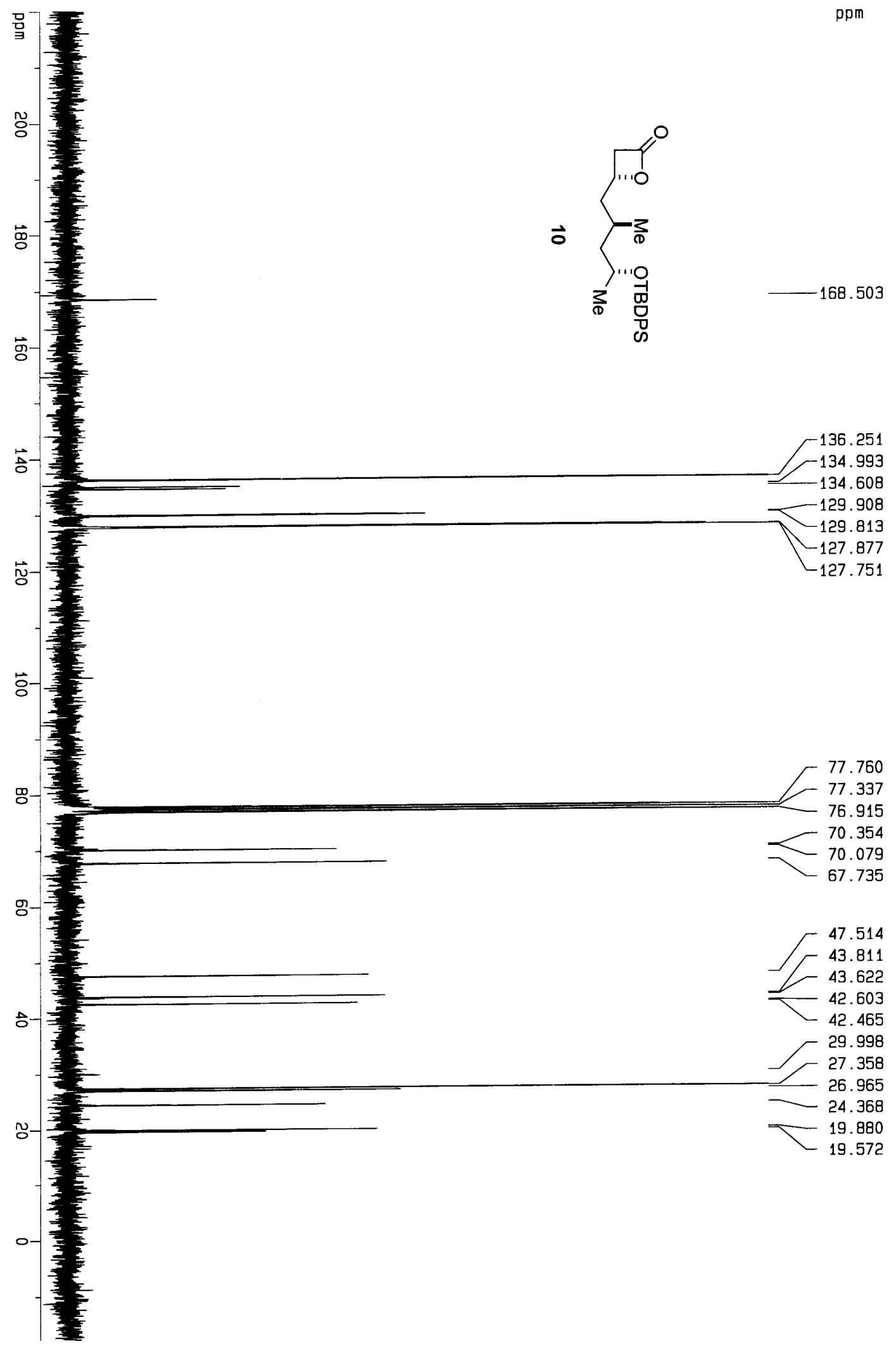




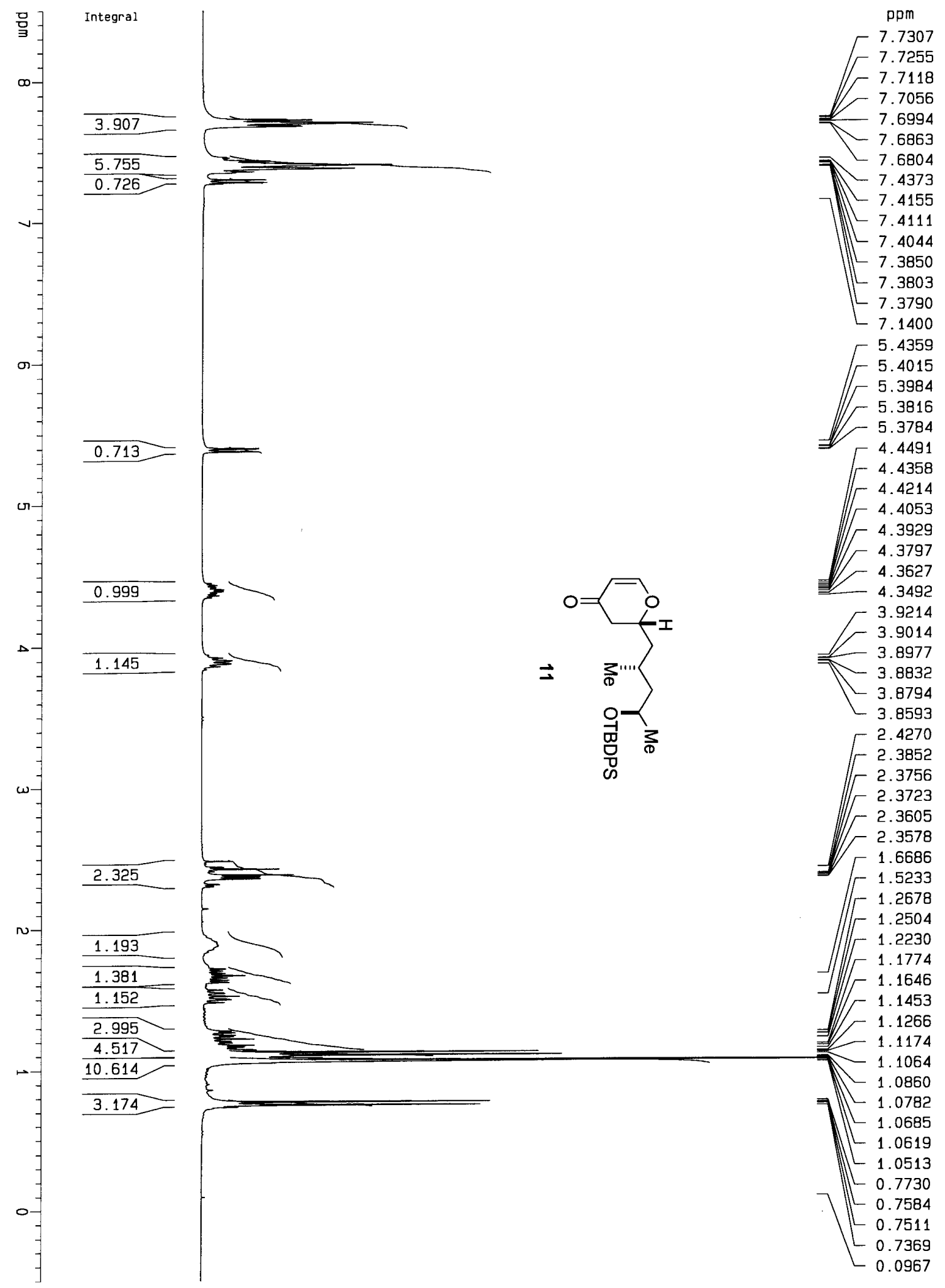




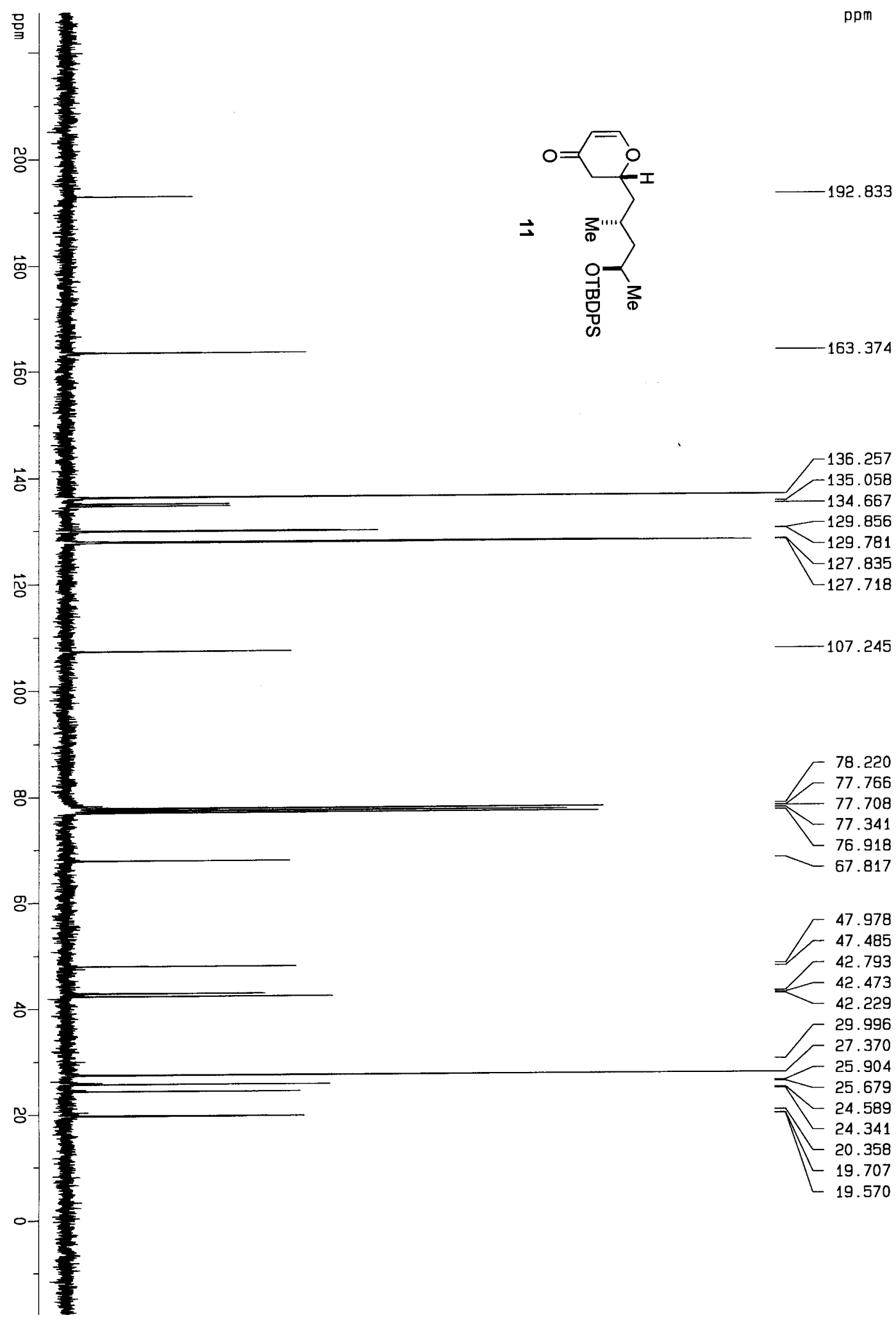




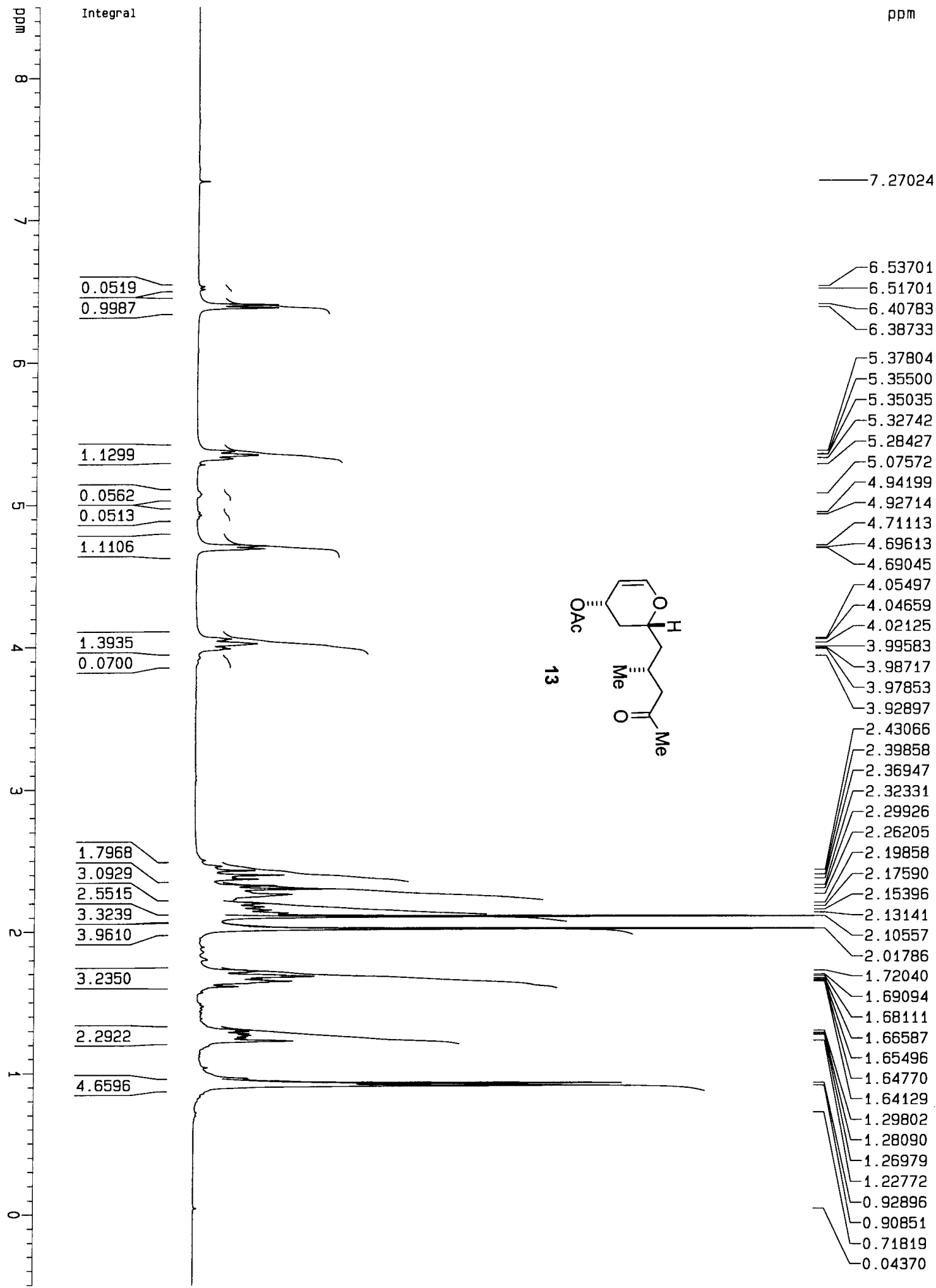




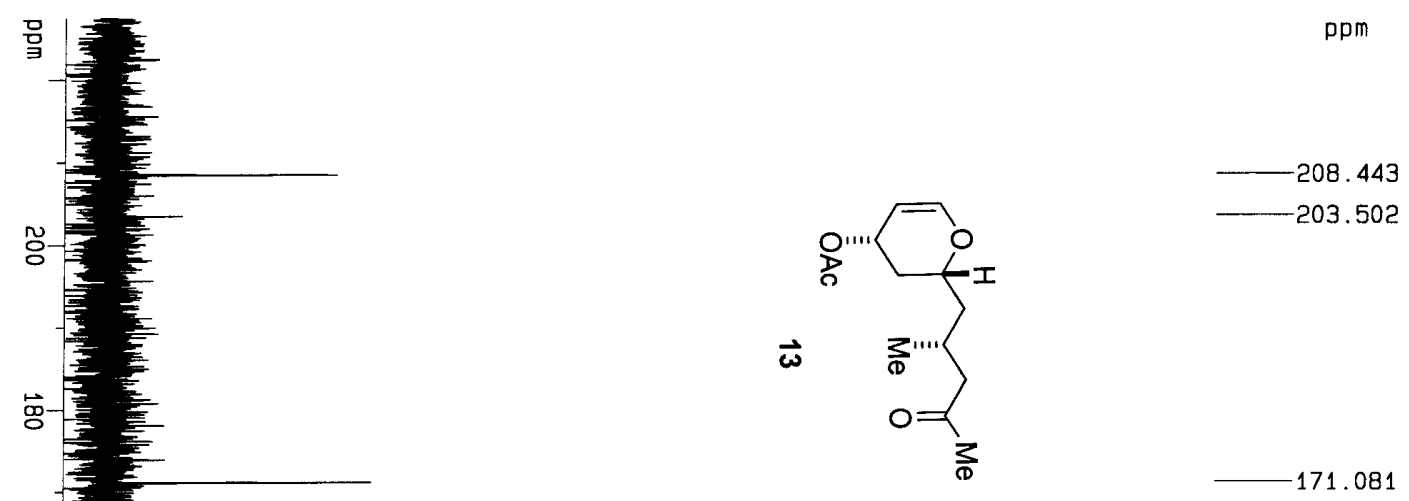

窝

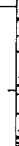

능-

용

果

을

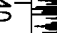
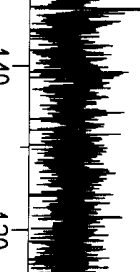

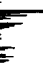




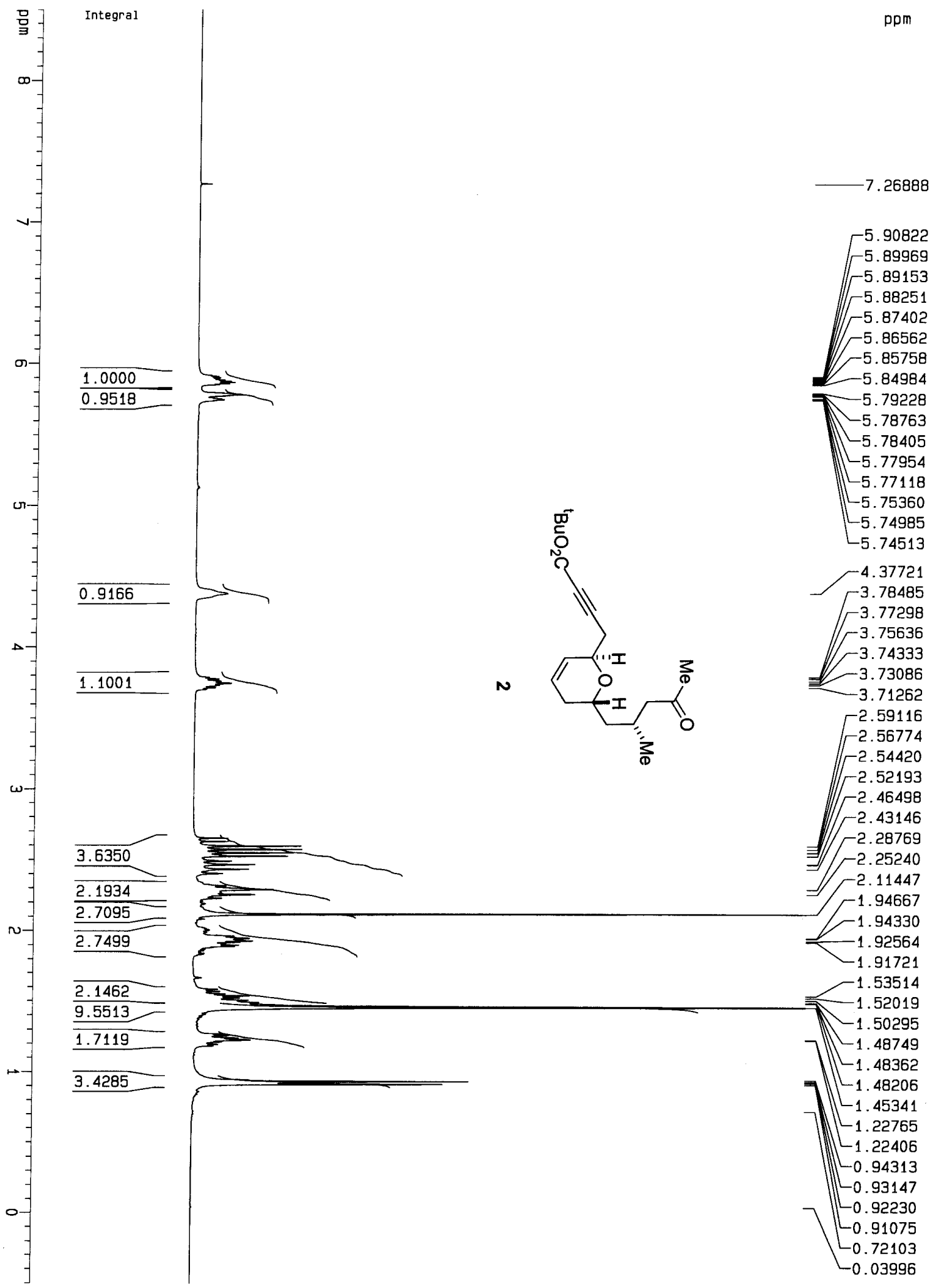




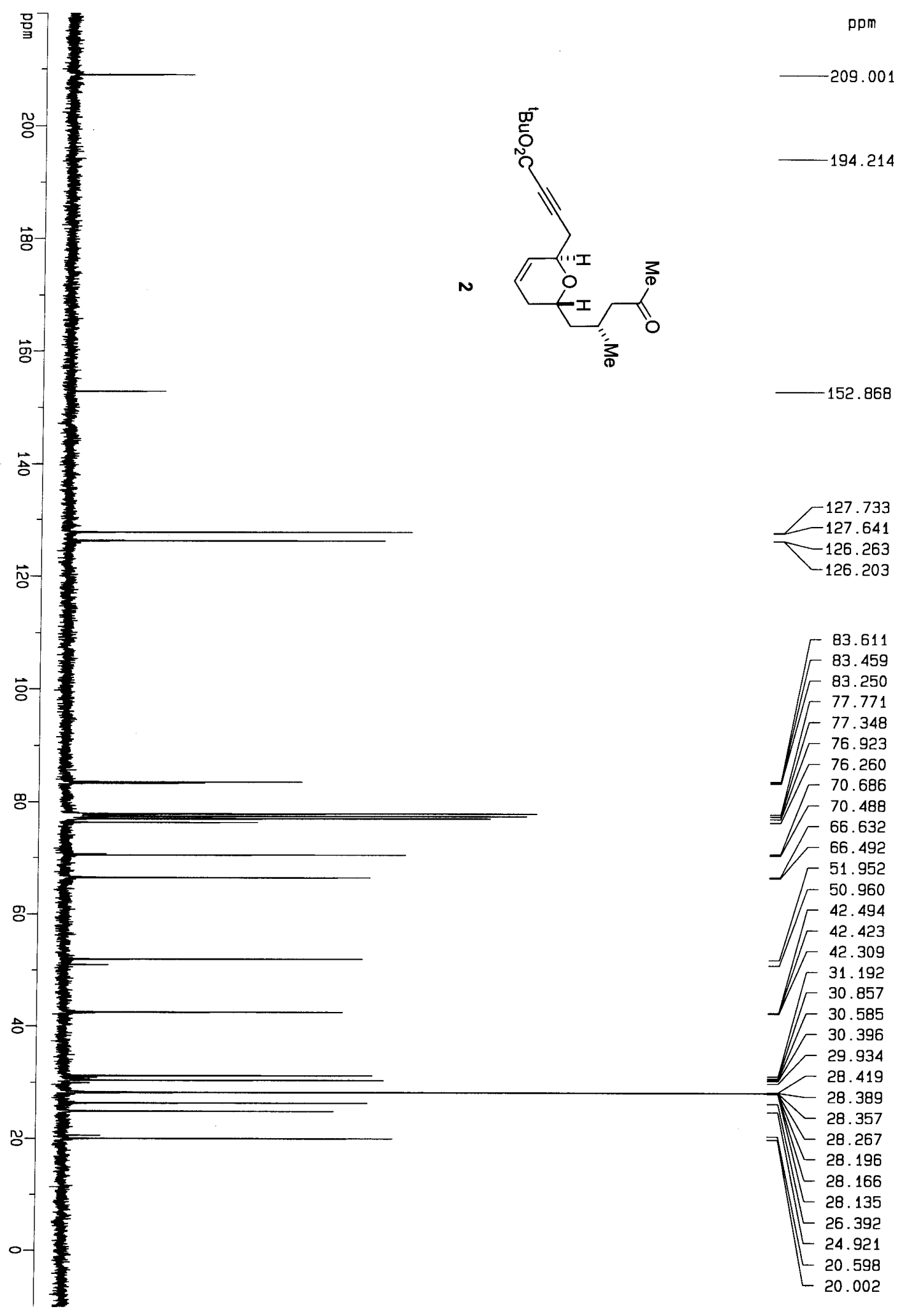




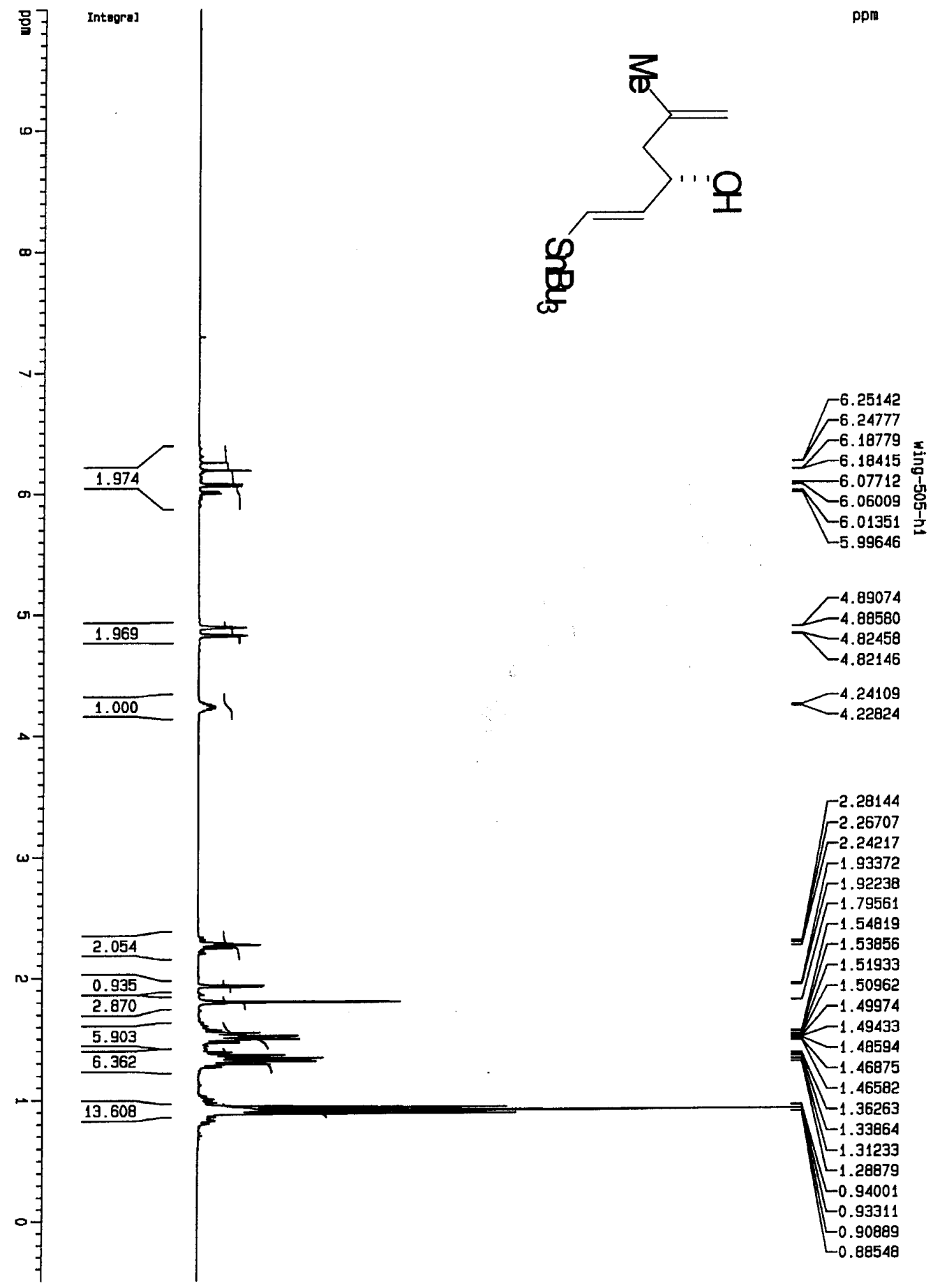



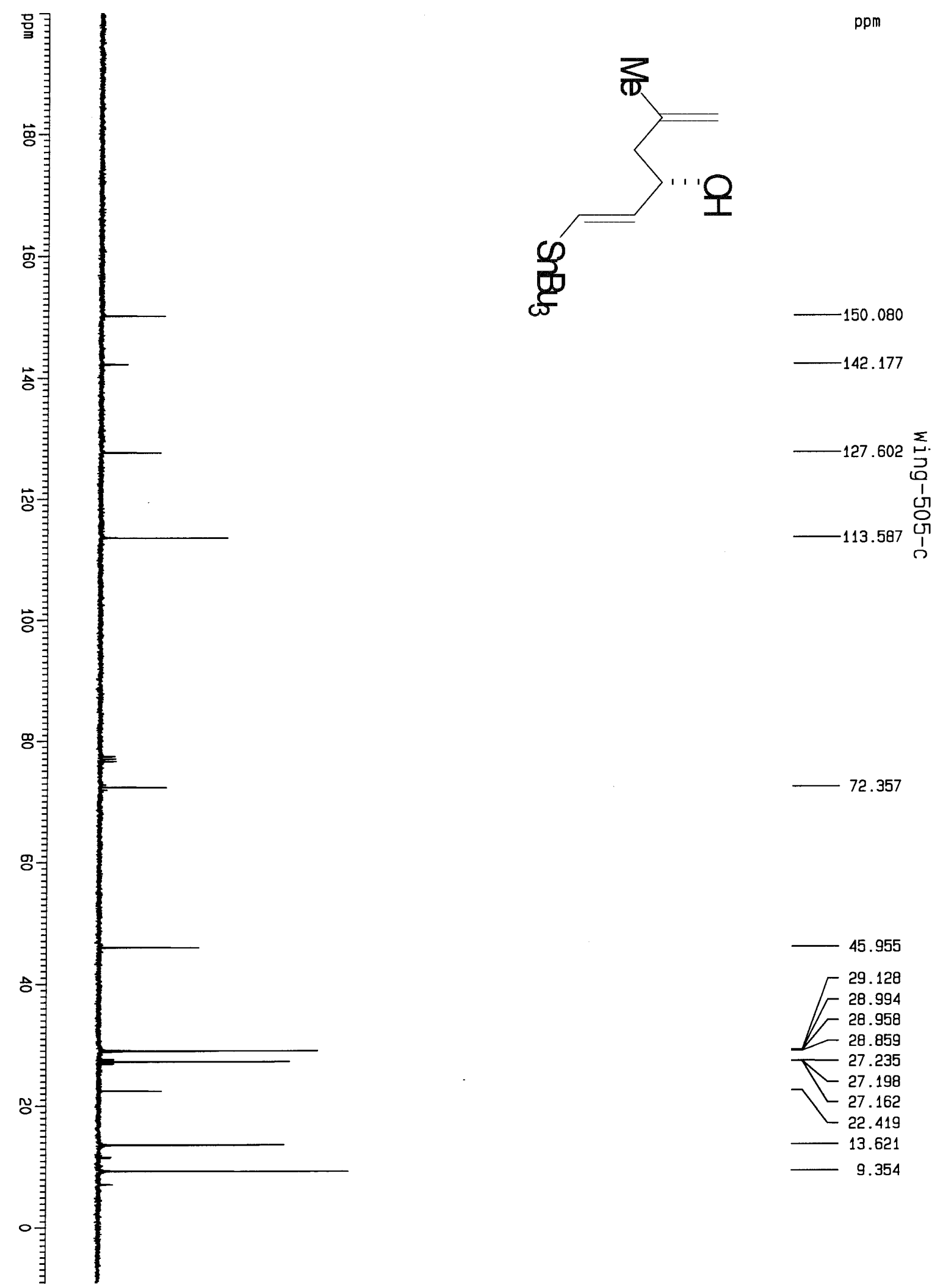

72.357

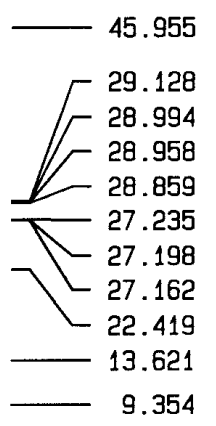




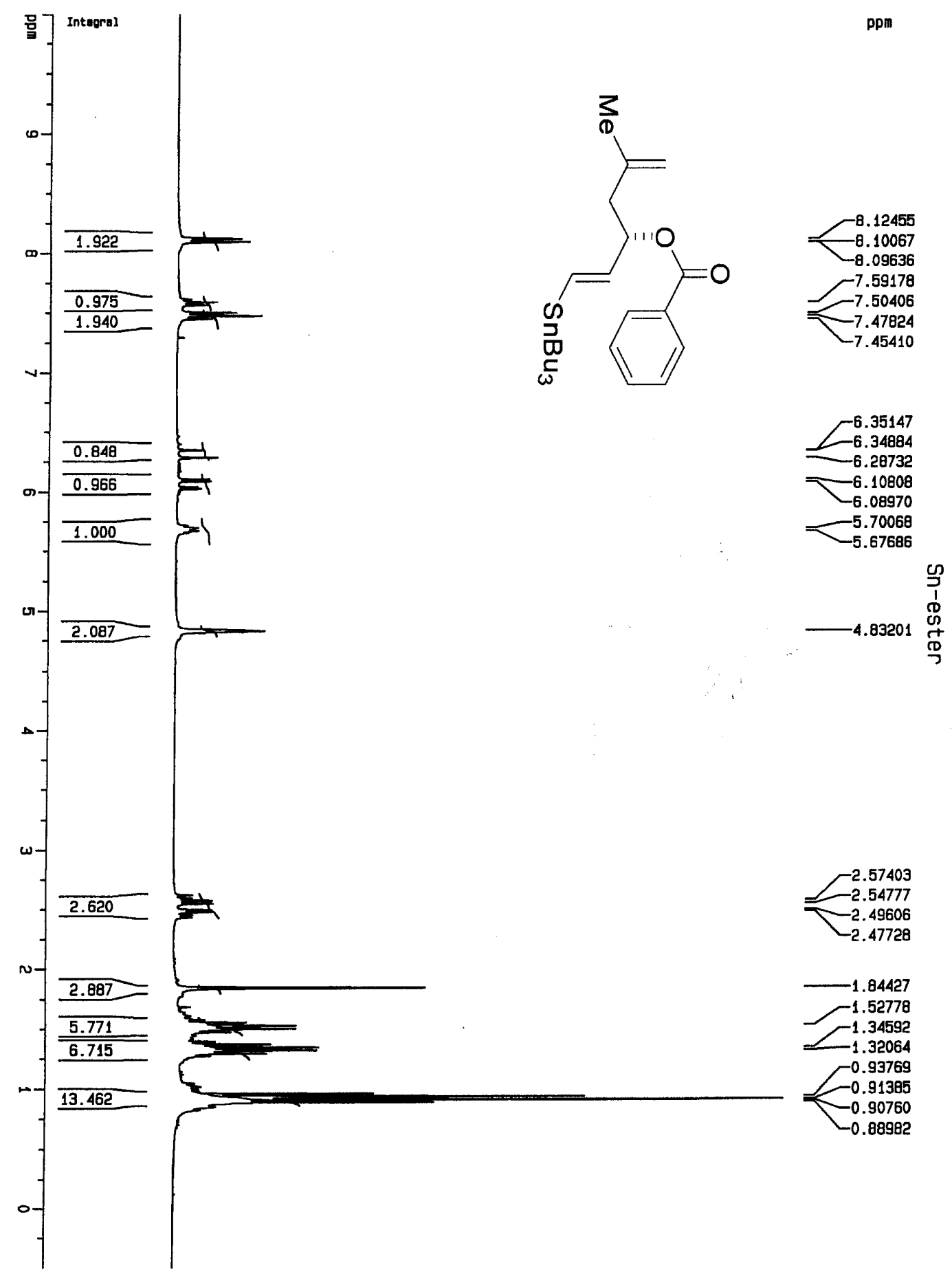



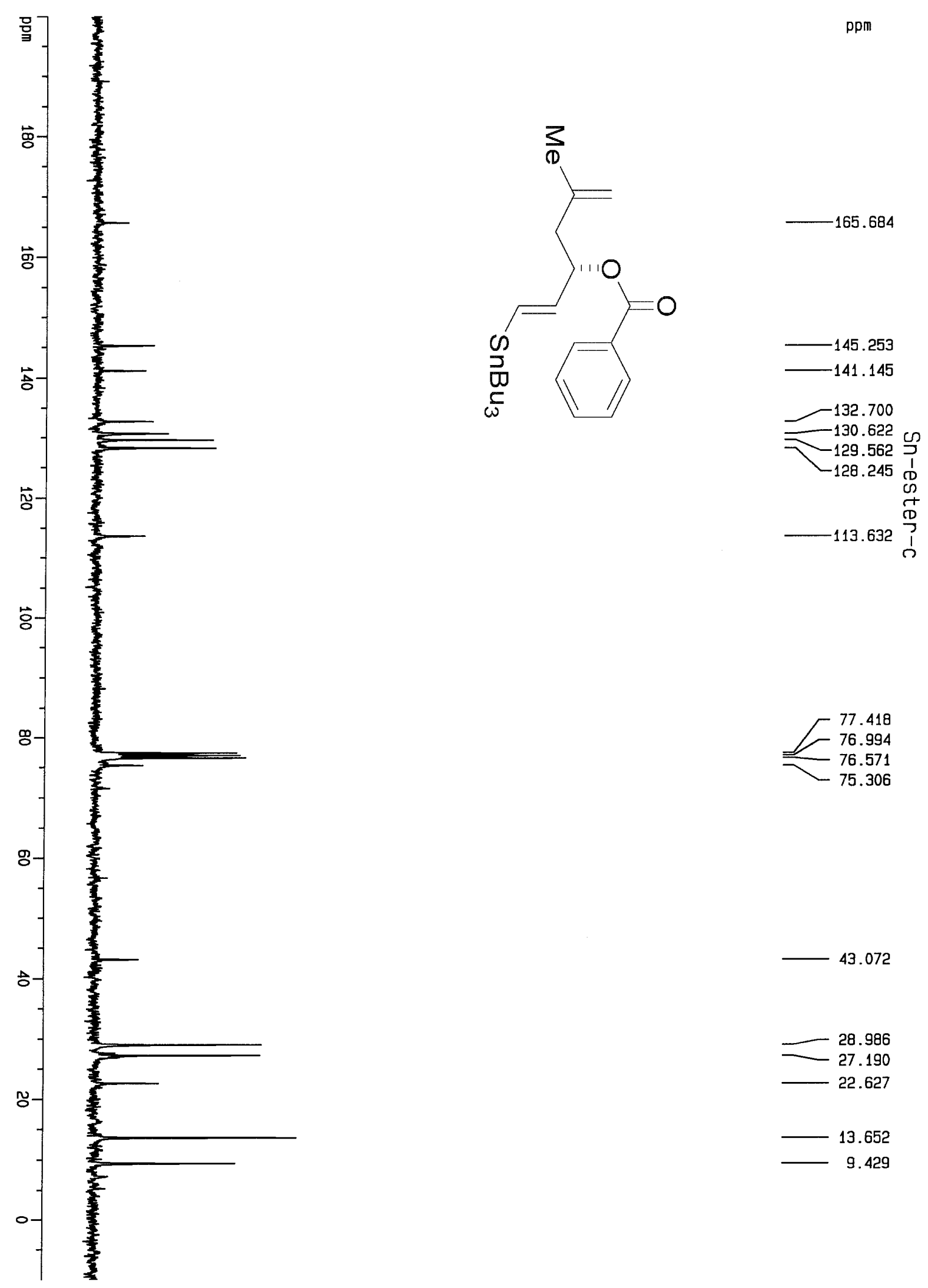

43.072

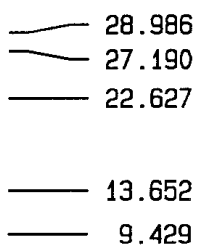




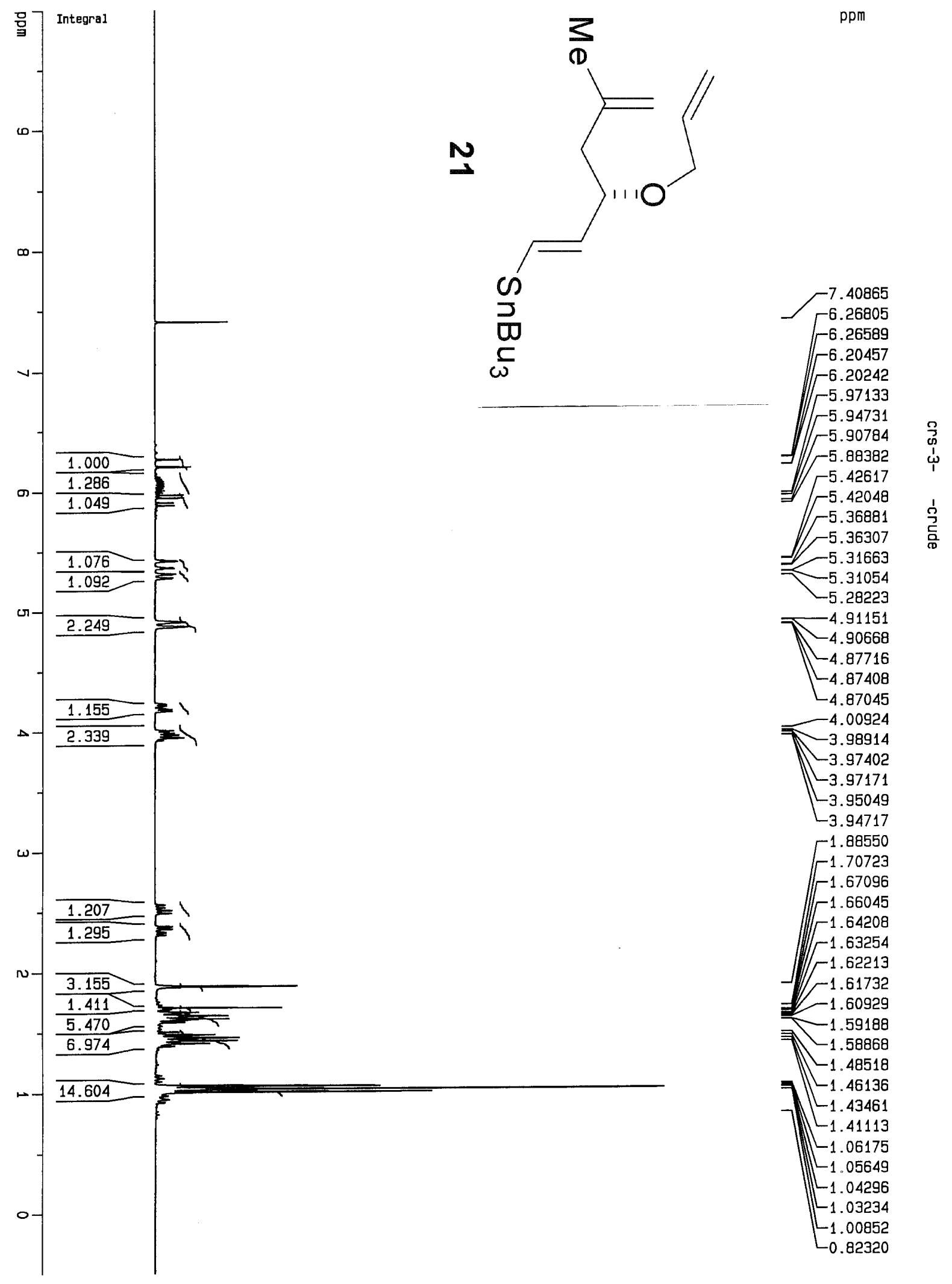




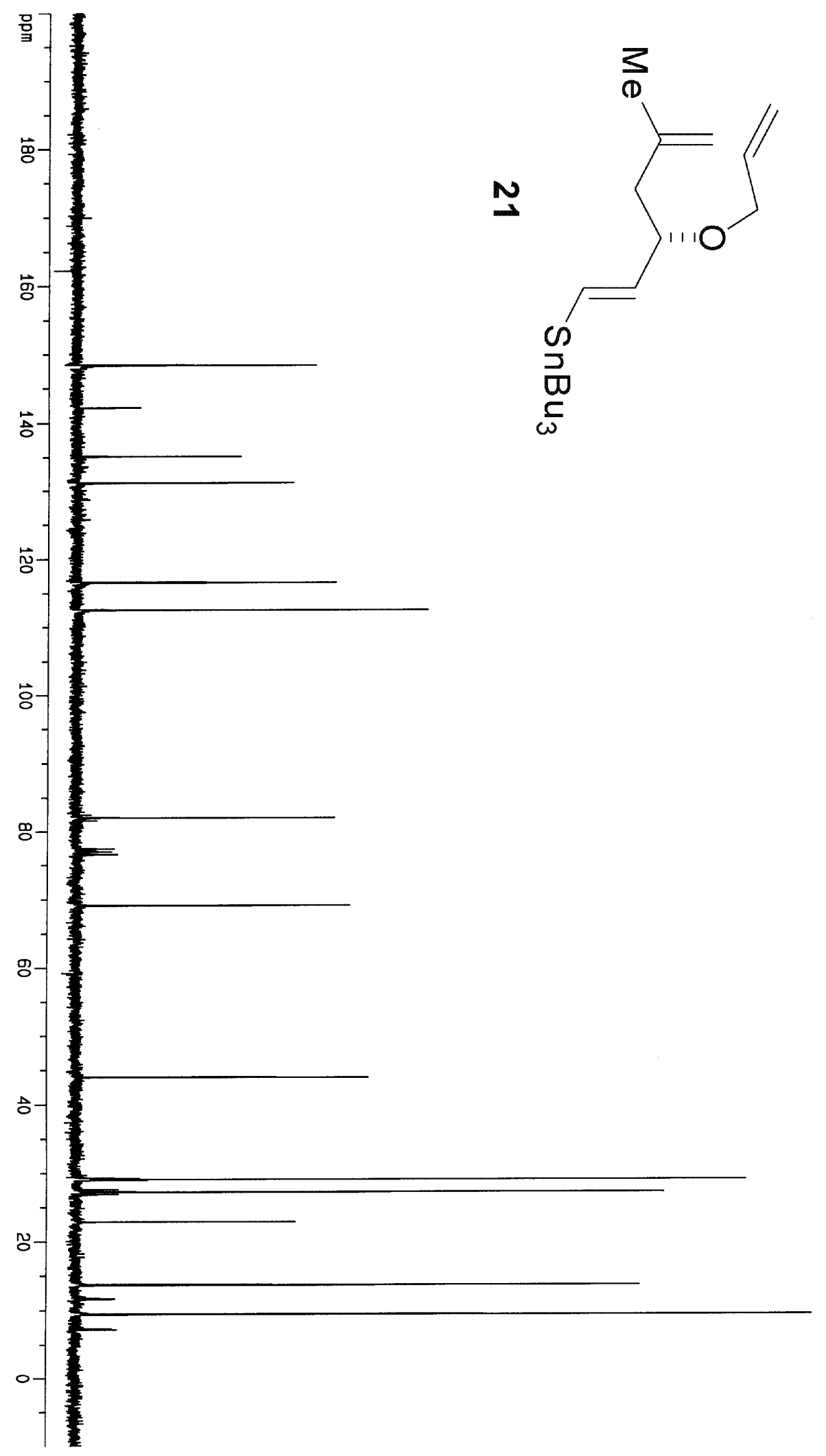

ppm
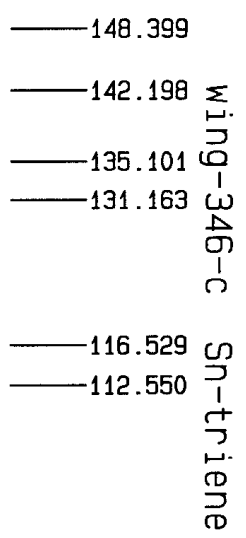

81.973

69.083

43.955

29.208

$-29.069$

28.933

= 27.552

$-27.197$

$\longleftarrow 26.850$

$\llcorner 22.863$

13.683

9.449 


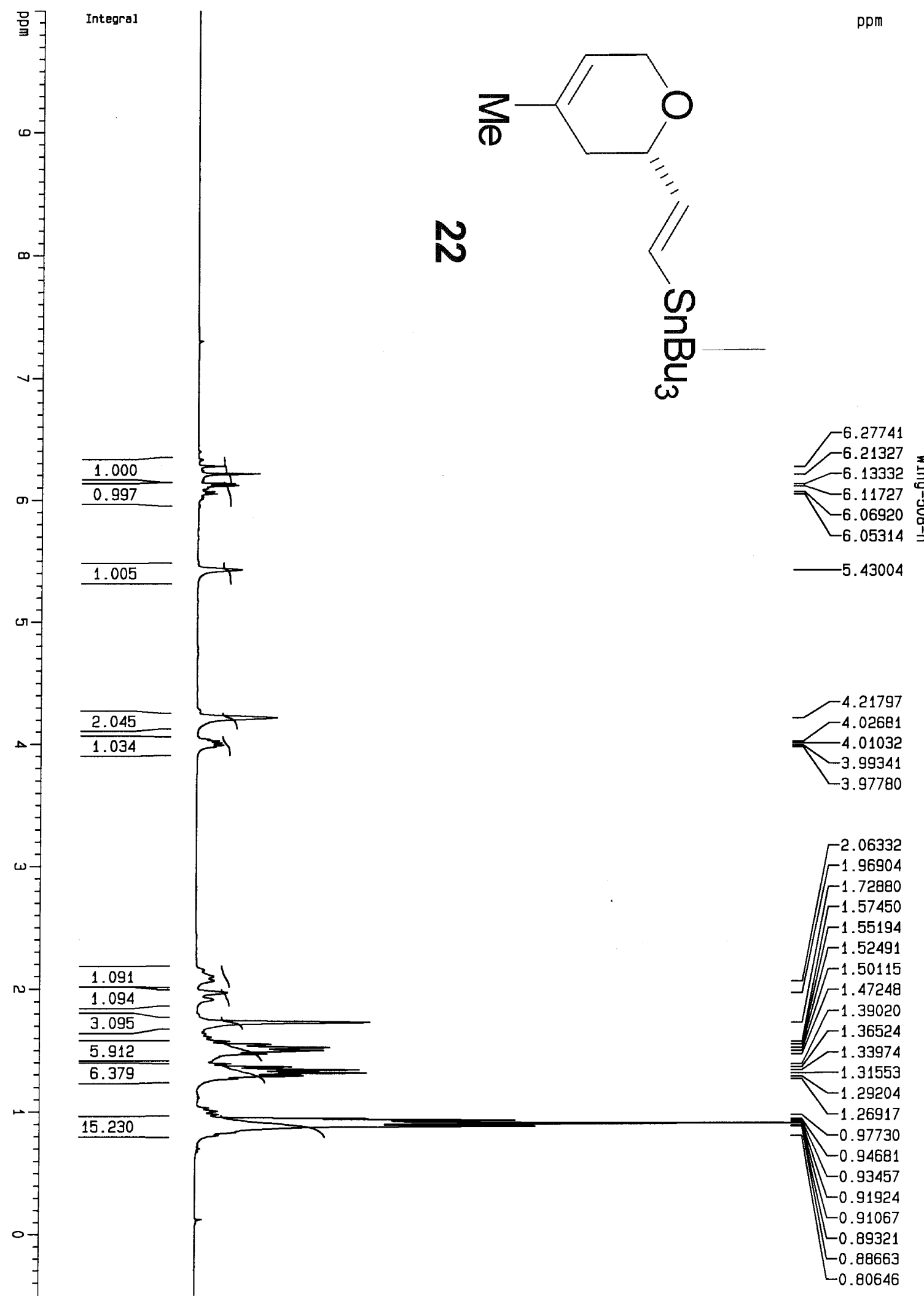



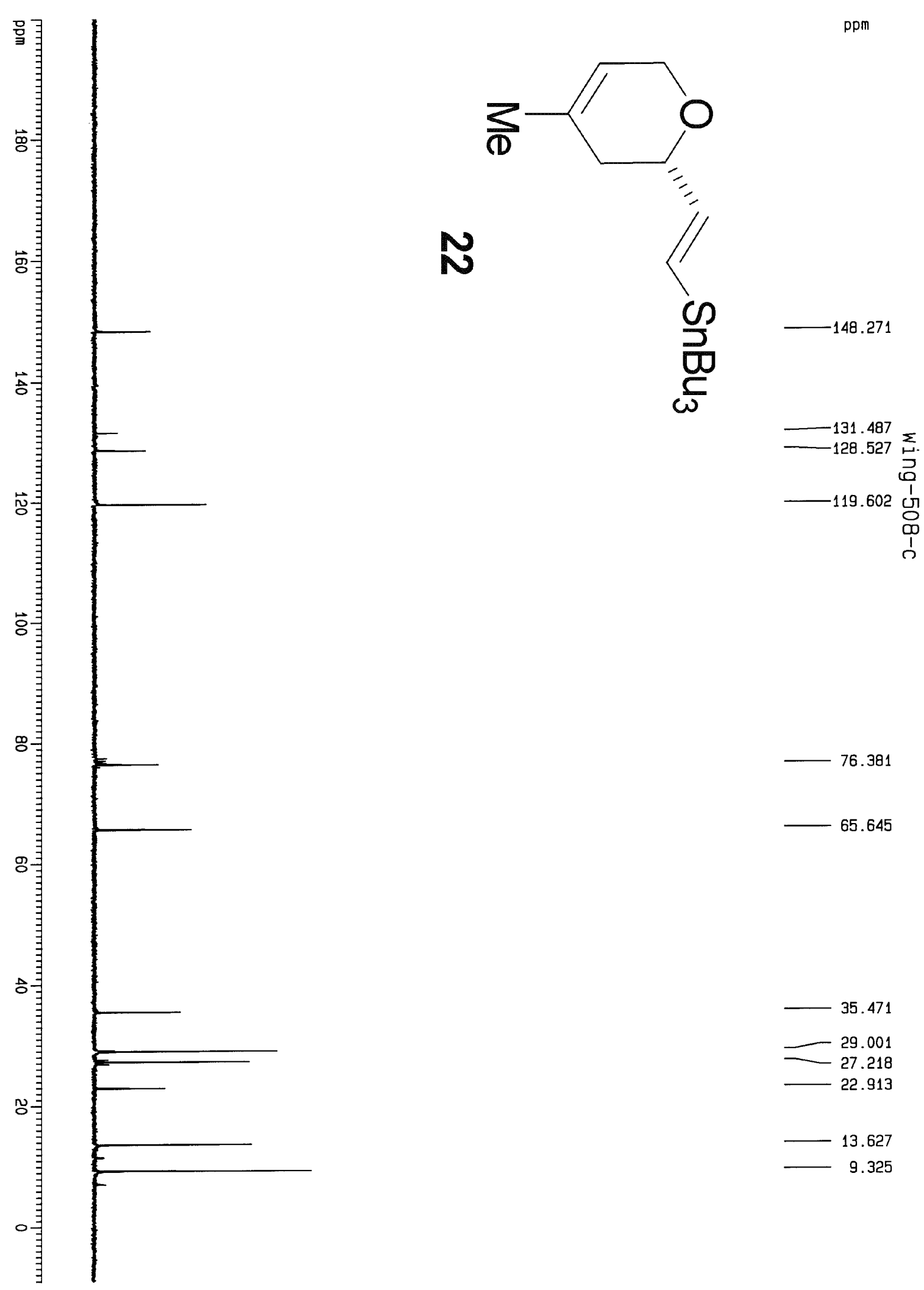


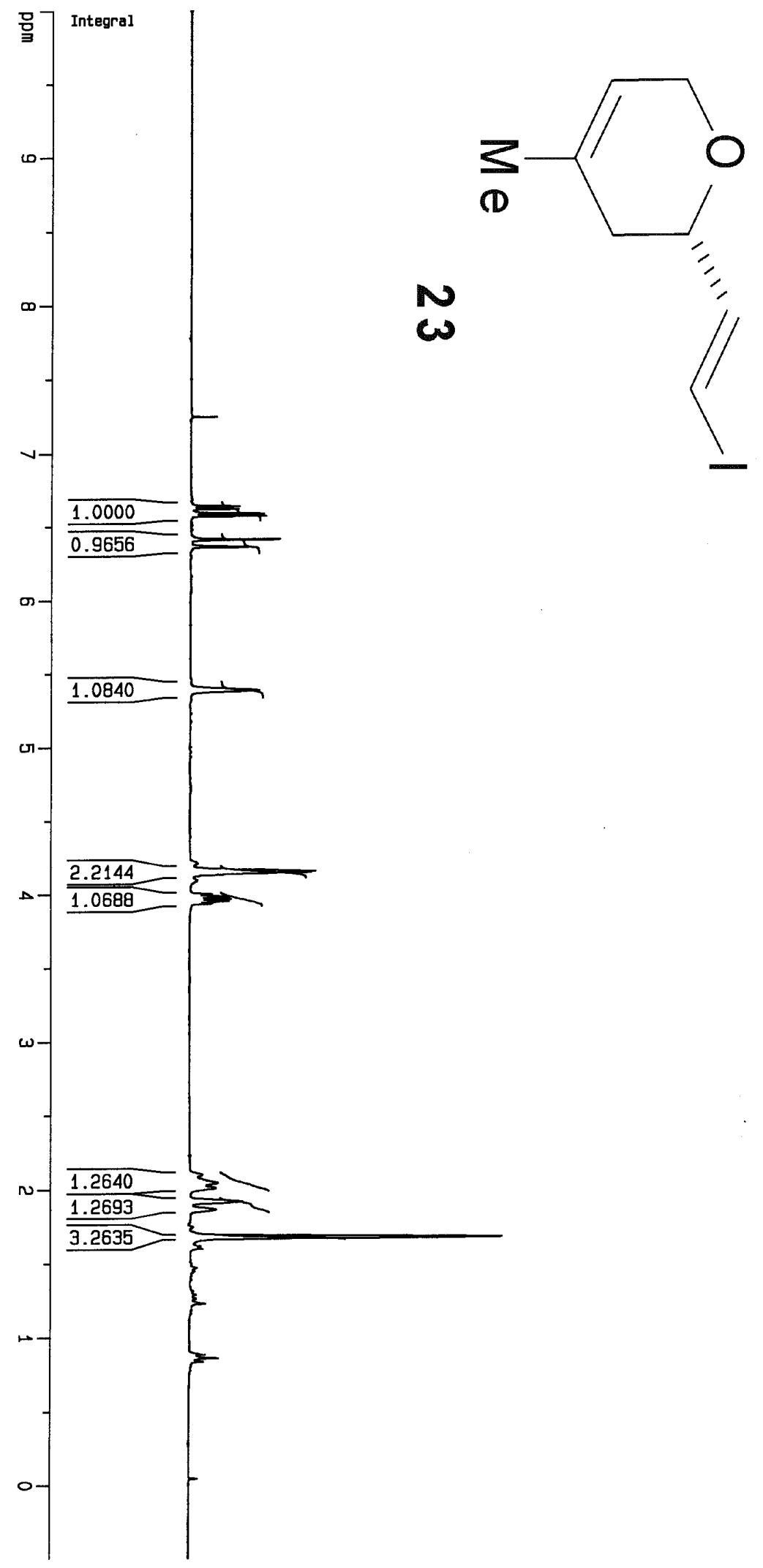

ppm

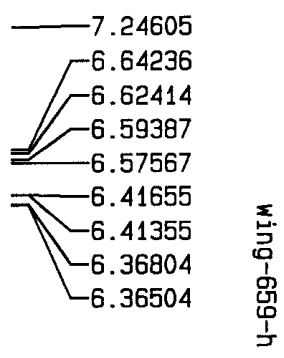

$-5.39358$

$-4.15984$

4.15277

3.98830

$-3.97145$

3.95514

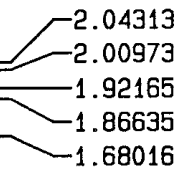

$-0.86083$ 

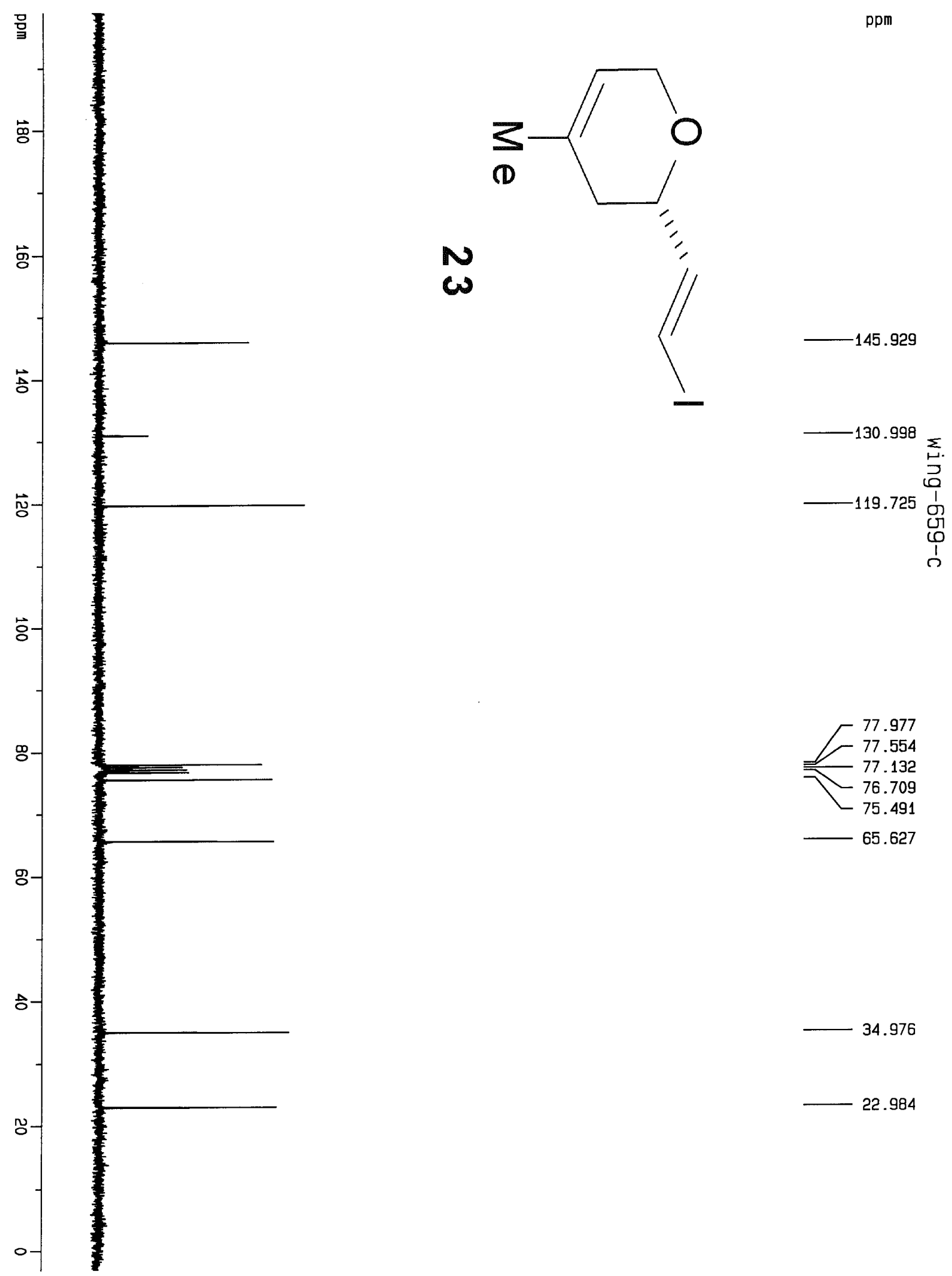

22.984 


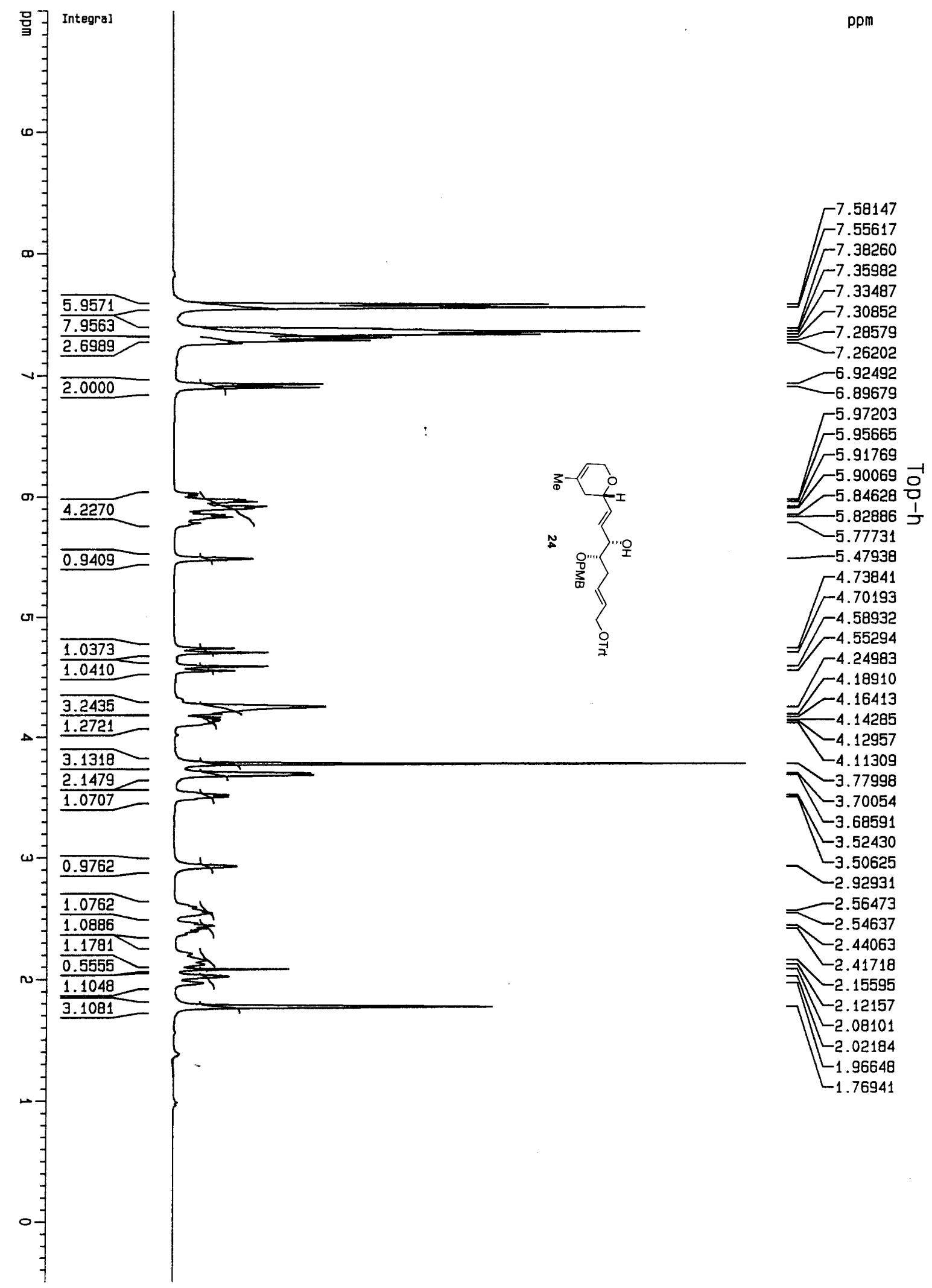




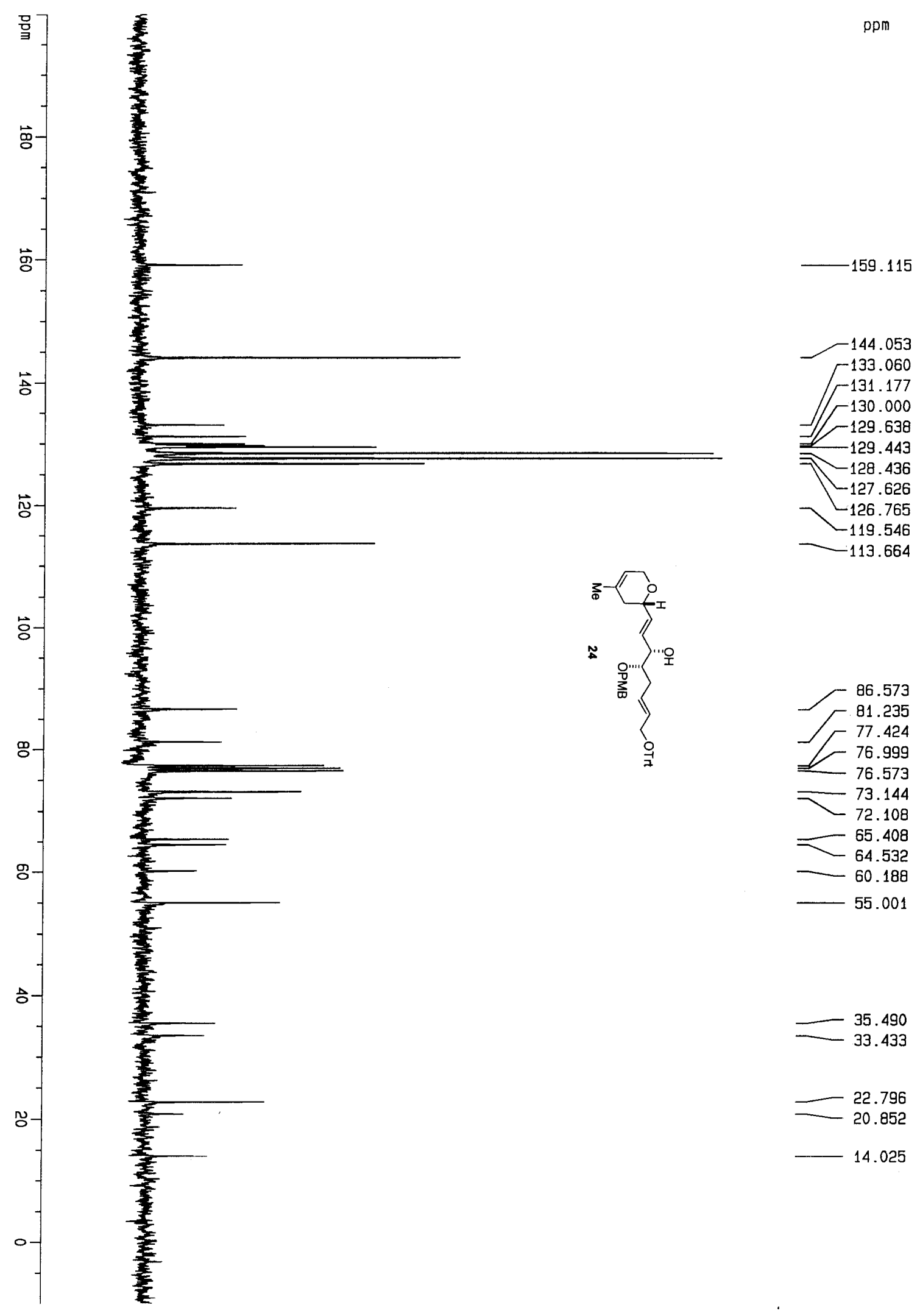




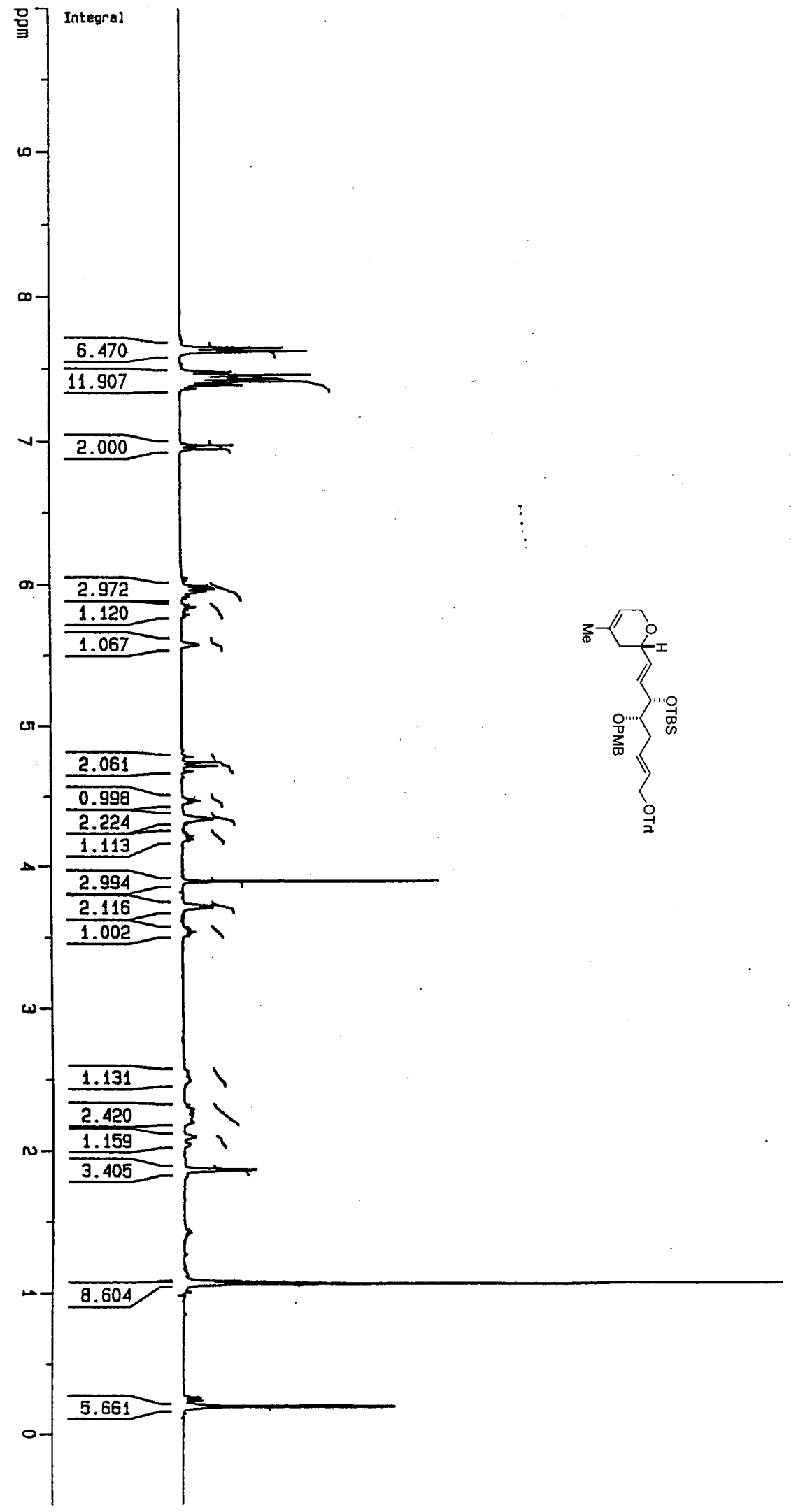

$\mathrm{ppm}$

7.6510

$-7.6467$

7.6400

7.6235

7.6200

$-7.6113$

$-7.4853$

$-7.4798$

7.4736

7.4419

7.4320

- 7.4130

$-7.4083$

- 7.3984

7.3898

$-6.9746$

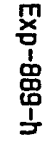

- 6.9683

$-5.9954$

5.9815

L 5.9707

5.9549

$-5.9452$

凤 $\left[\begin{array}{l}5.8437 \\ 5.5805\end{array}\right.$

] $\left[\begin{array}{l}-4.7821 \\ 4.7445\end{array}\right.$

$\left[\begin{array}{l}4.7190 \\ -4.6819\end{array}\right.$

4.6812

] $\left[\begin{array}{l}4.4855 \\ -4.4685\end{array}\right.$

]

$-4.3415$

$-4.2300$

4.1968

- 3.8957

- 3.7231

$-3.7069$

[ 3.5407

ح-2.2946

$7-2.2471$

ᄂ2.2096

$-2.1000$

1.8674

T 1.4477

1.4299
1.4242

$-1.0037$

$-1.0745$

$-1.0647$

0.2655

$-0.2431$

$-0.2165$

$-0.1992$

$-0.1936$ 


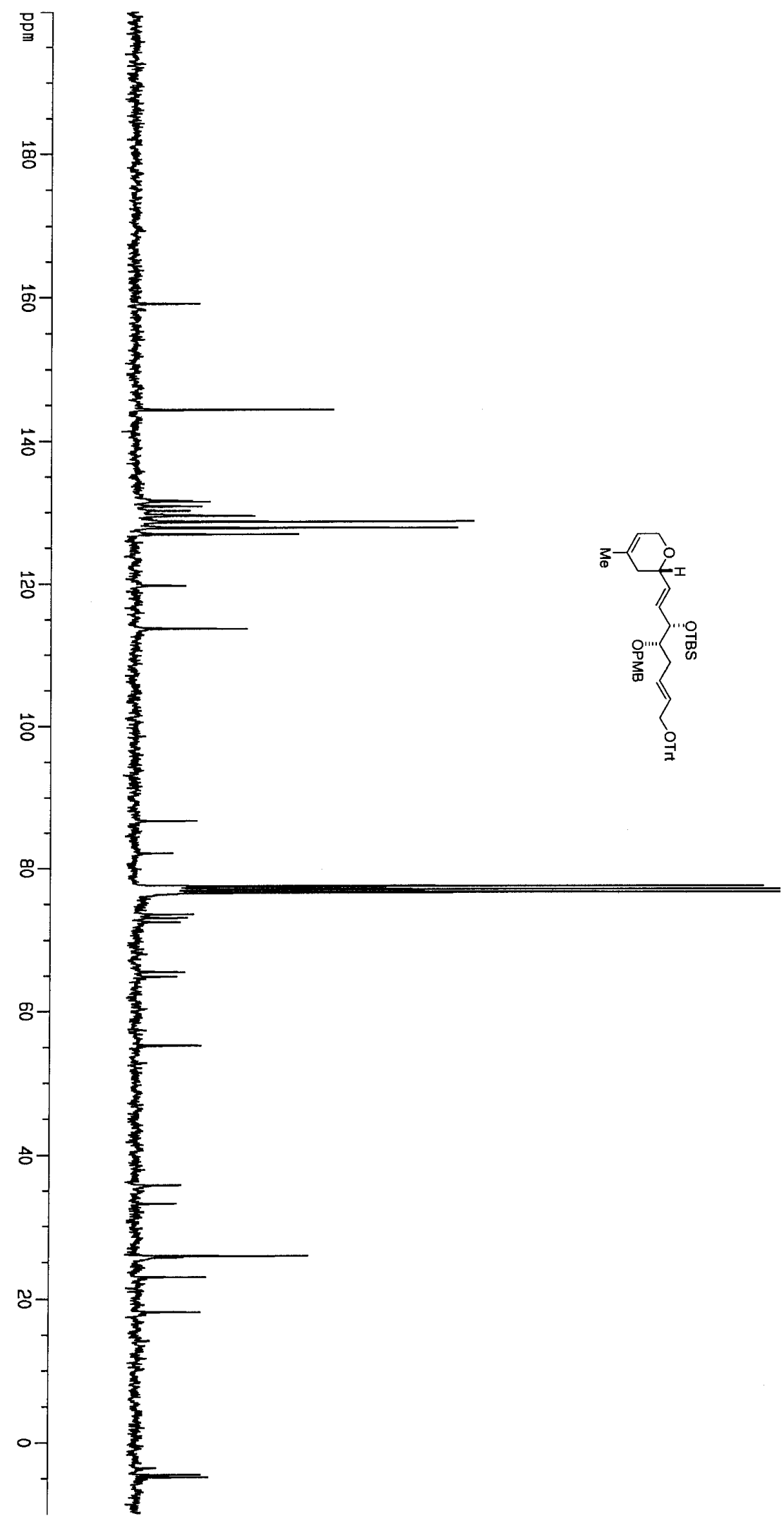

ppm
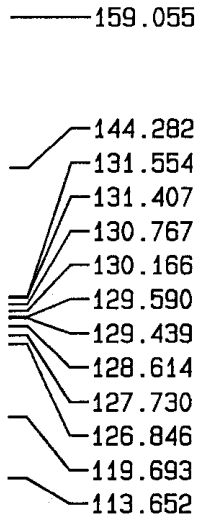

罟
$\vdots$
1
0
0
0
0
0

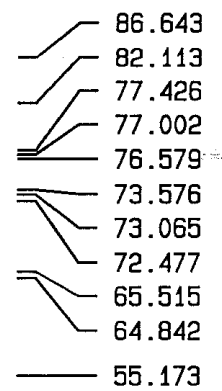

35.723

33.154

25.863

25.616

22.950

18.146

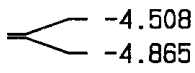




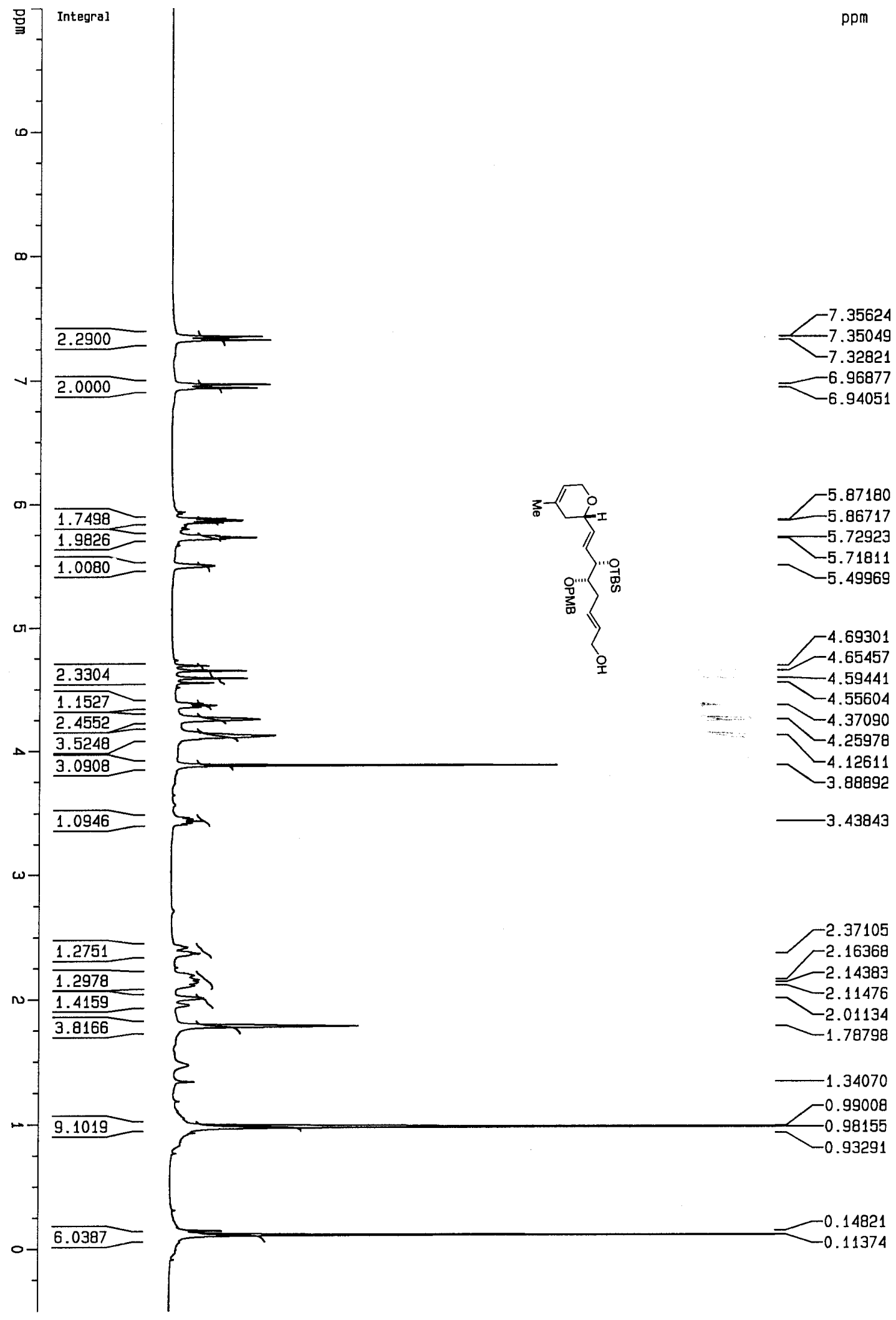




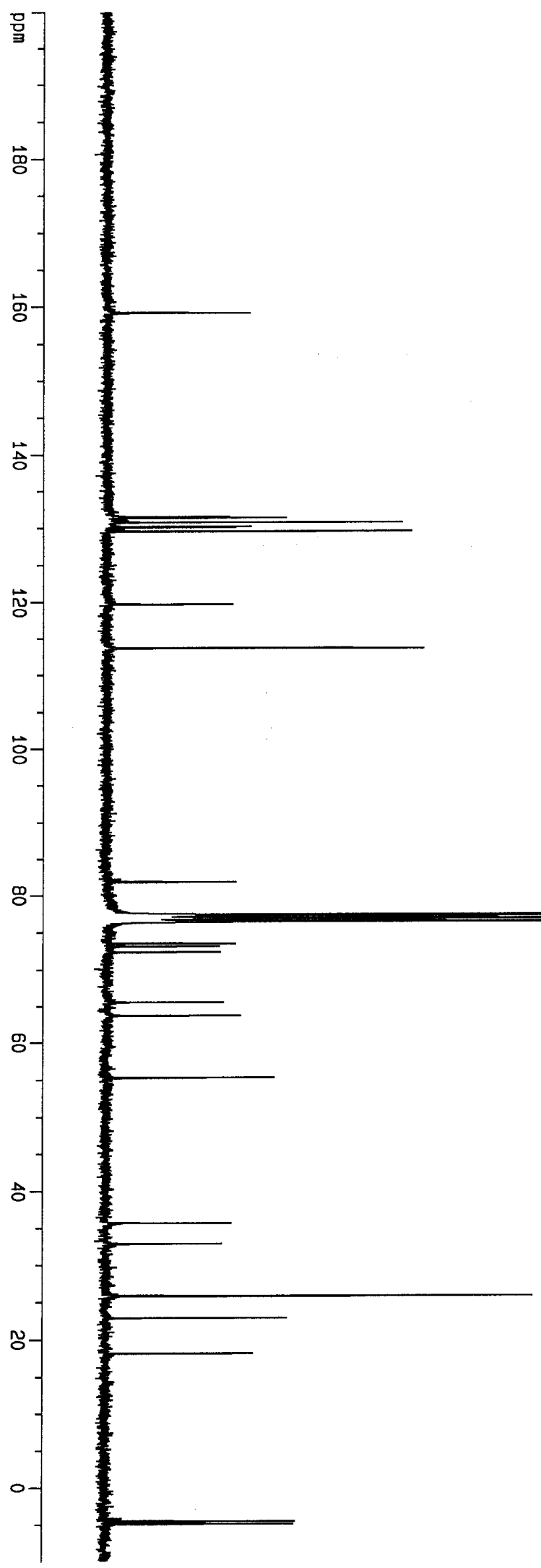

ppm
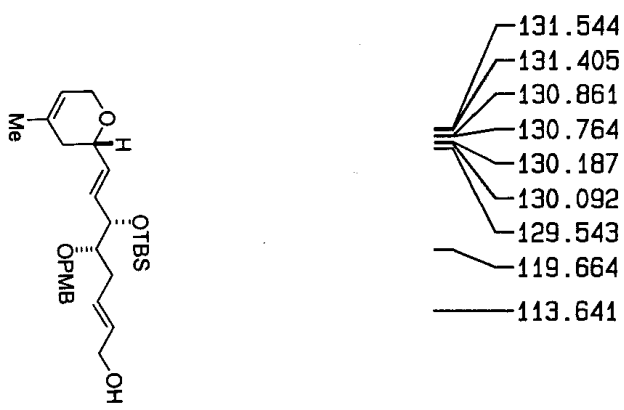

$-81.830$

r 77.427

T 77.207

$-77.003$

- 73.536

$-73.116$

72.345

$-65.555$

-63.761

55.268

$-22.952$

$-18.148$ 


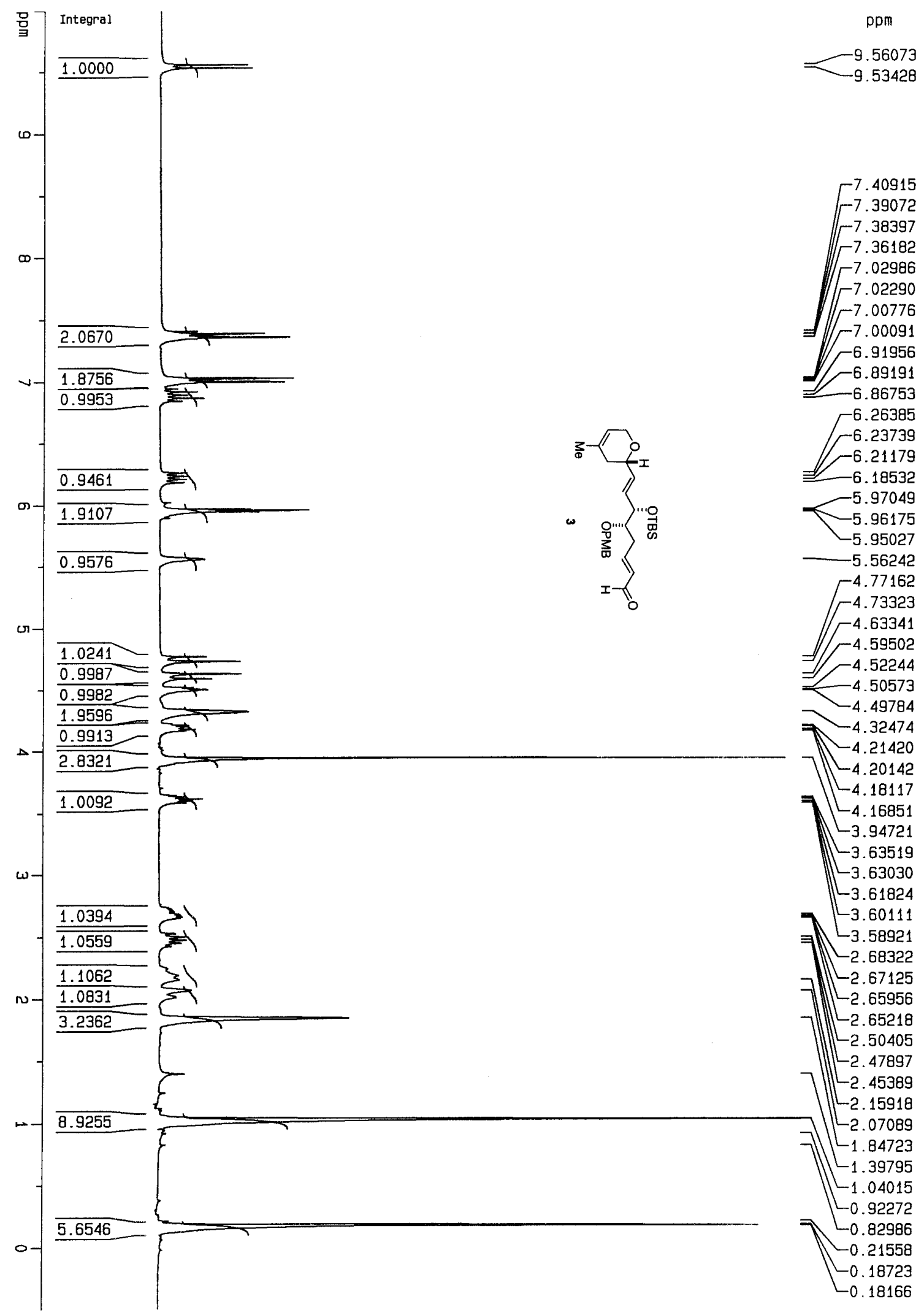



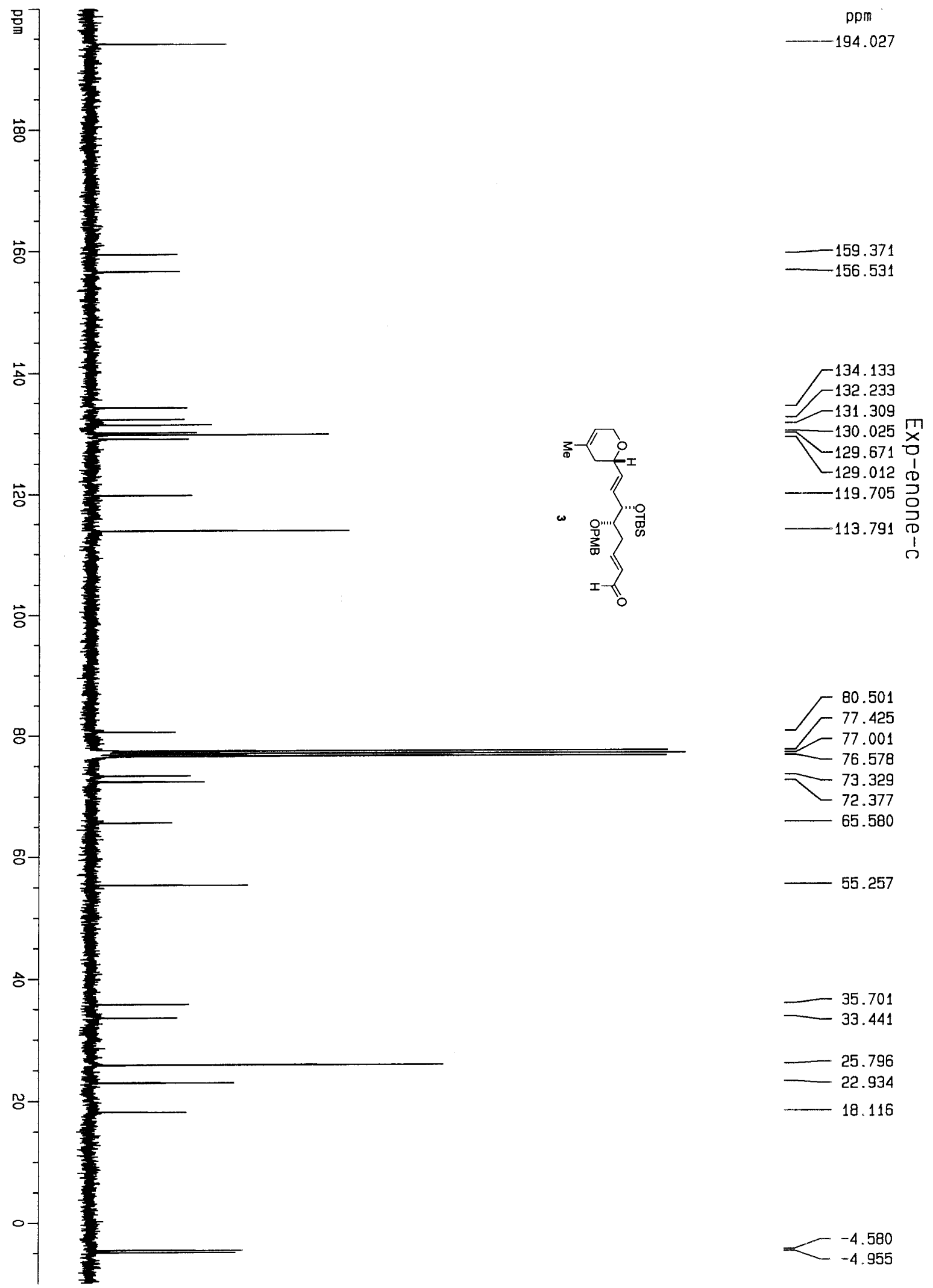

55.257

159.371

156.531

35.701

33.44

25.796

22.934

18. 116 


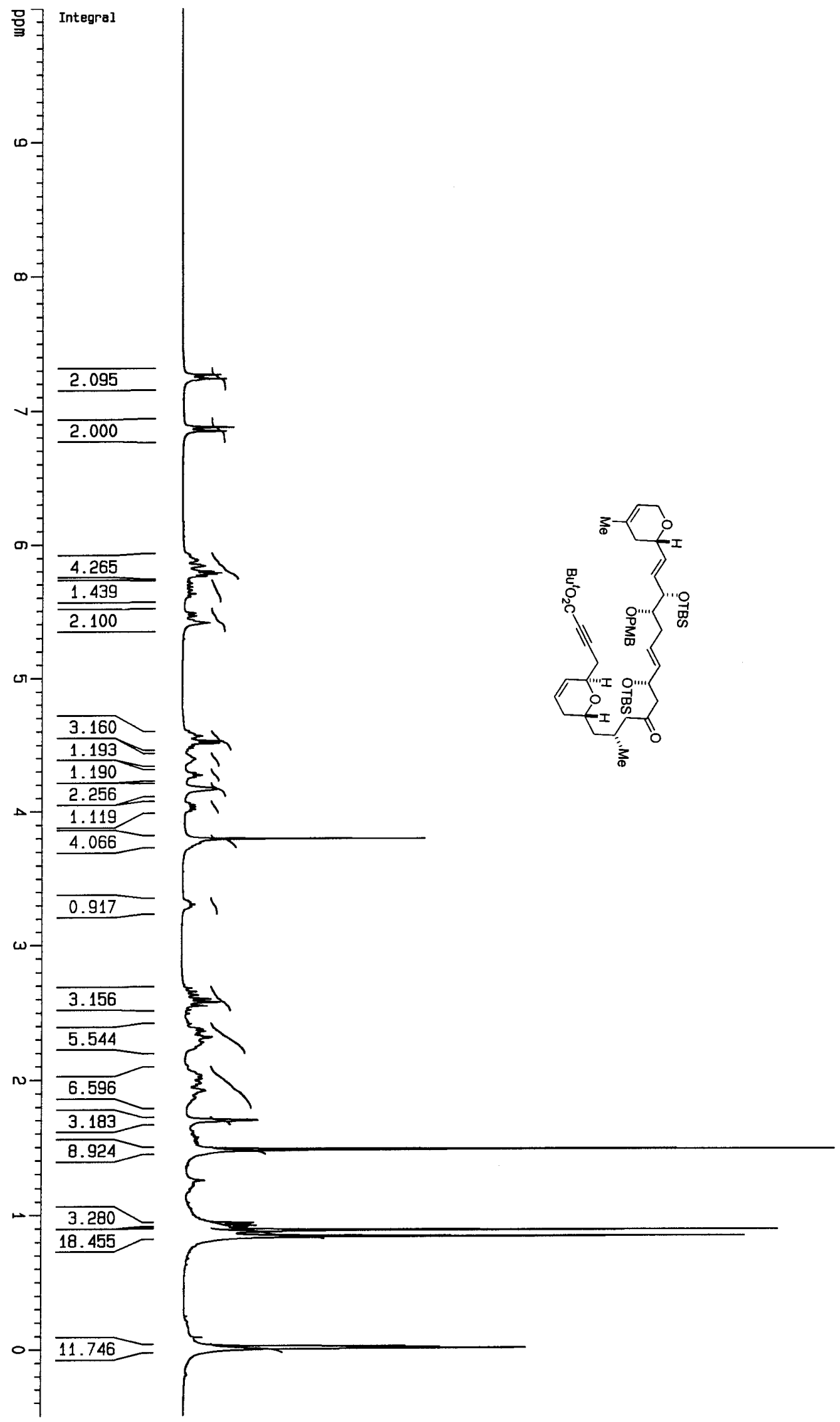

$\mathrm{ppm}$

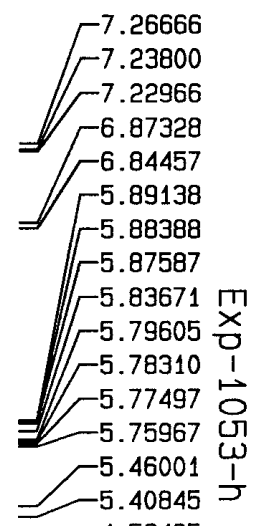

4.56485

4.52741

4.51148

4.28539

4.26919

$-4.25649$

$-3.79341$

$-3.76331$

2.62867

$-2.59876$

$-2.57548$

$-2.54974$

$-2.37634$

$-2.36030$

$-2.34015$

$\exists-2.32506$

-2.31559
-2.37836

$-2.02993$

$\approx-2.00686$

$-1.97381$

$-1.91786$

$-1.69631$

$-1.48007$

$-1.25191$

$\mathbb{Z}_{-0.93991}^{0.91969}$

$-0.90932$

$-0.88402$

$-0.83821$

$-0.08894$

$-0.01896$

$-0.01160$

$L_{0.00545}$ 


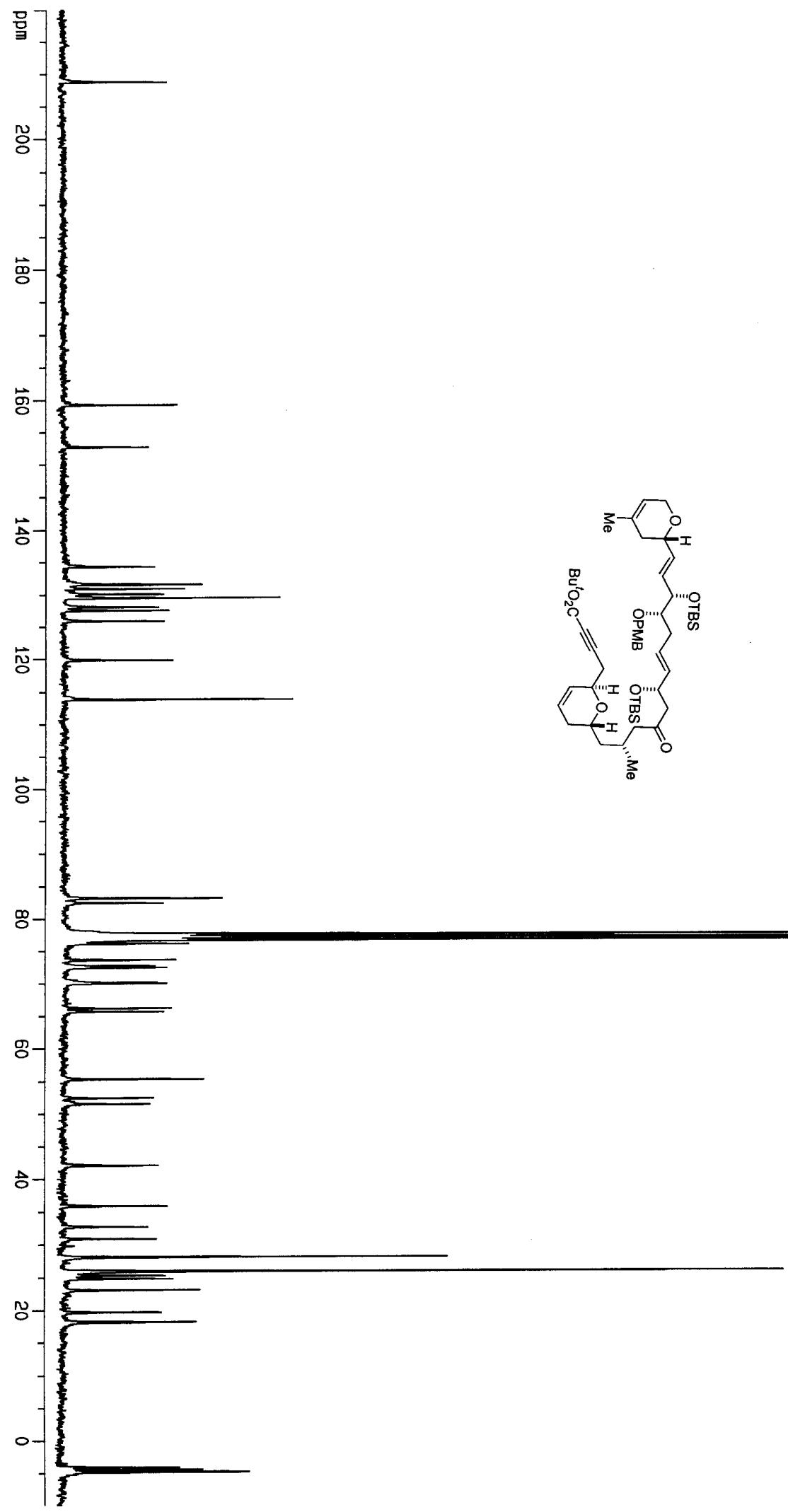

ppm

113.783

[ 83.163

82.427

77.585

F 77.161

- 76.738

- 76.165

$=-73.645$

- 72.754

- 72.466

70.224

$-70.038$

66.156

- 65.659

$-55.354$

$-52.436$

51.531

T 42.090

$\tau 5.834$

32.710

- 30.858

28.091

$\begin{array}{r}25.974 \\ -\quad 25.313 \\ \hline\end{array}$

$-24.847$

$7-23.080$

$\checkmark 19.731$

$-18.263$

$-18.178$

$F_{-}^{-4.061}$

$-4.767$ 


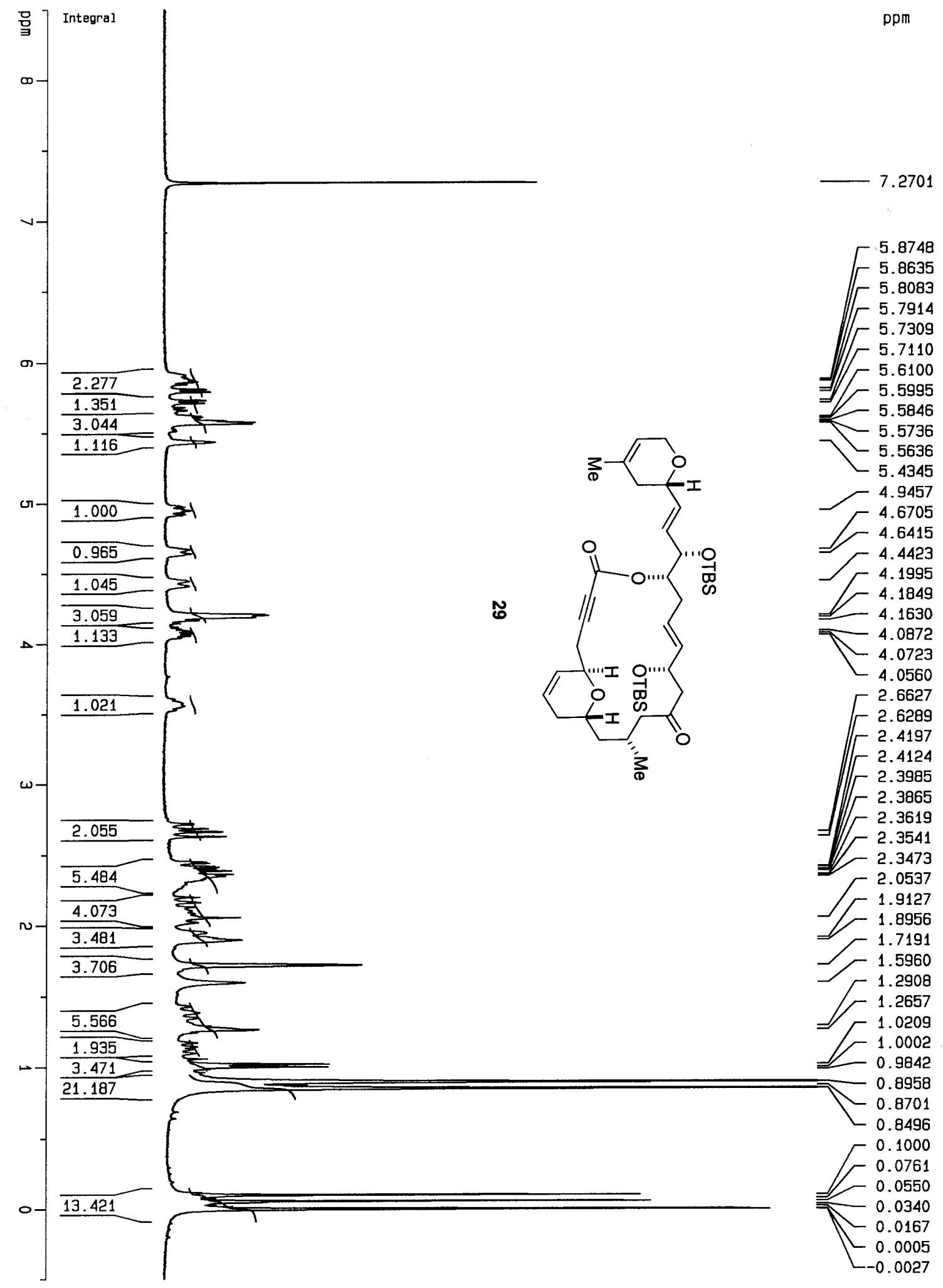




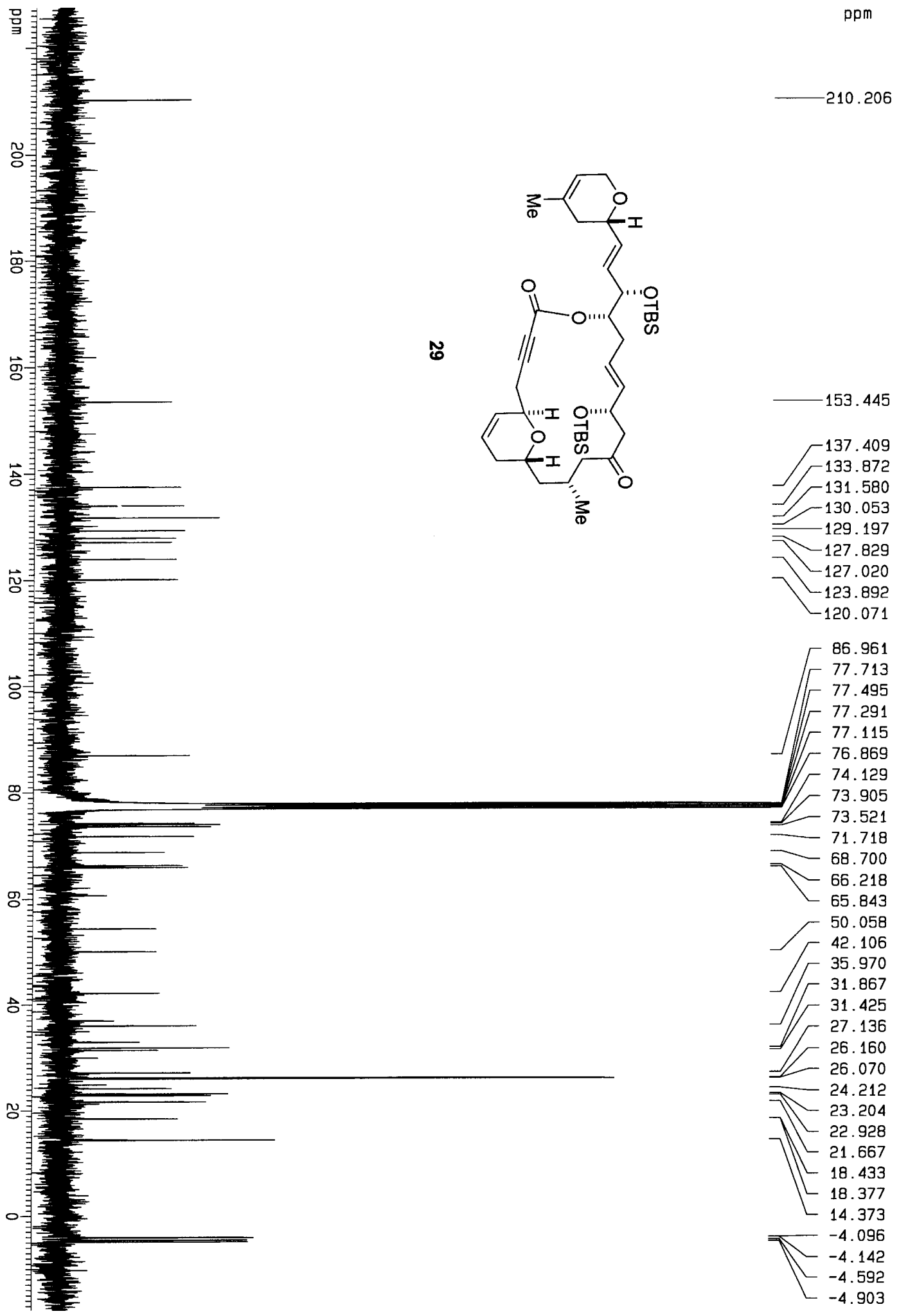




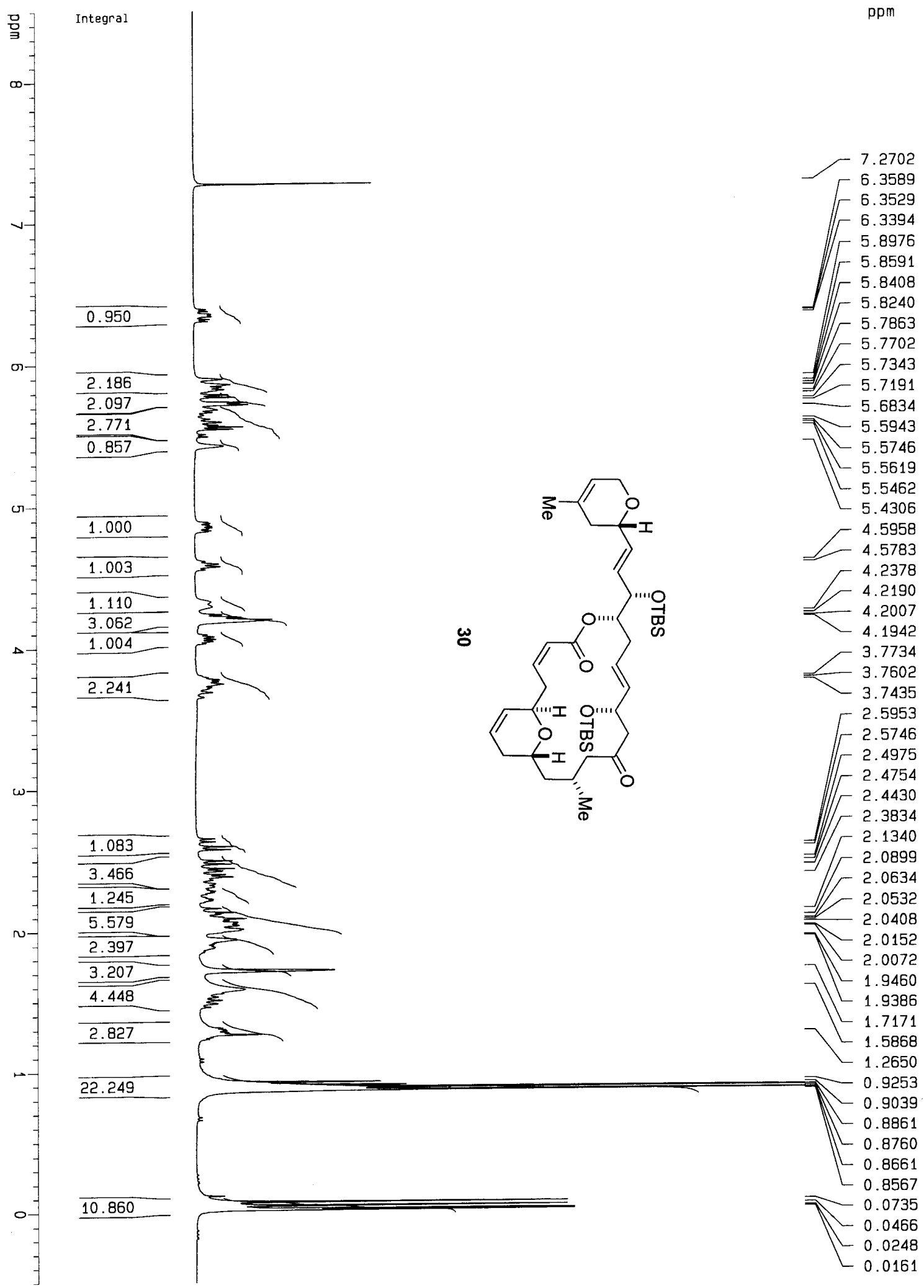


믑

㻤

ㅇ.

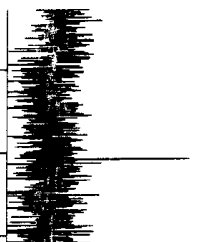

品-

앙

g)

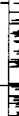

拿

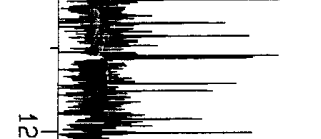

กิ

3

응

$\circ$

o

gr
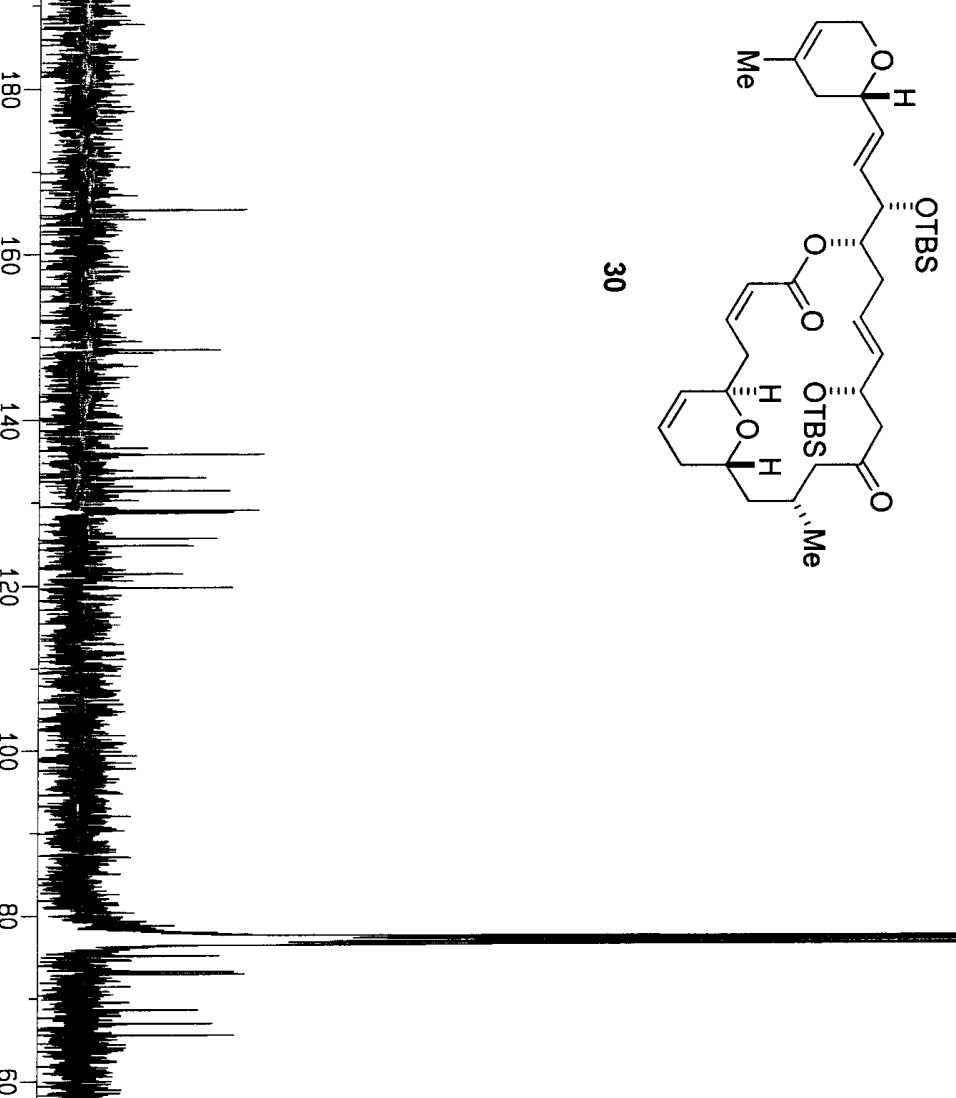

$=165.349$
-164.213

$-148.410$

$-148.039$

$\Gamma^{136.520}$

135.770

132.956

$-131.334$

$+129.043$

$-128.777$

$-125.715$

$-124.868$

$-121.445$

$-119.779$

79.352

78.813

$-78.635$

F 78.461

F 77.418

- 77.196

$-76.995$

$-76.570$

75.143

73.309
-73.243

$\leftarrow 72.958$

$-68.582$

L 66.936

65.540

$-51.778$

$-51.272$

$-42.549$

- 35.747

$-33.603$

$-31.605$

$-31.262$

$-28.744$

$-25.851$

$-25.763$

$\leftarrow 22.906$

- 20.961

L 18.130

$-18.070$

$--4.489$

$-4.910$

$-5.014$ 


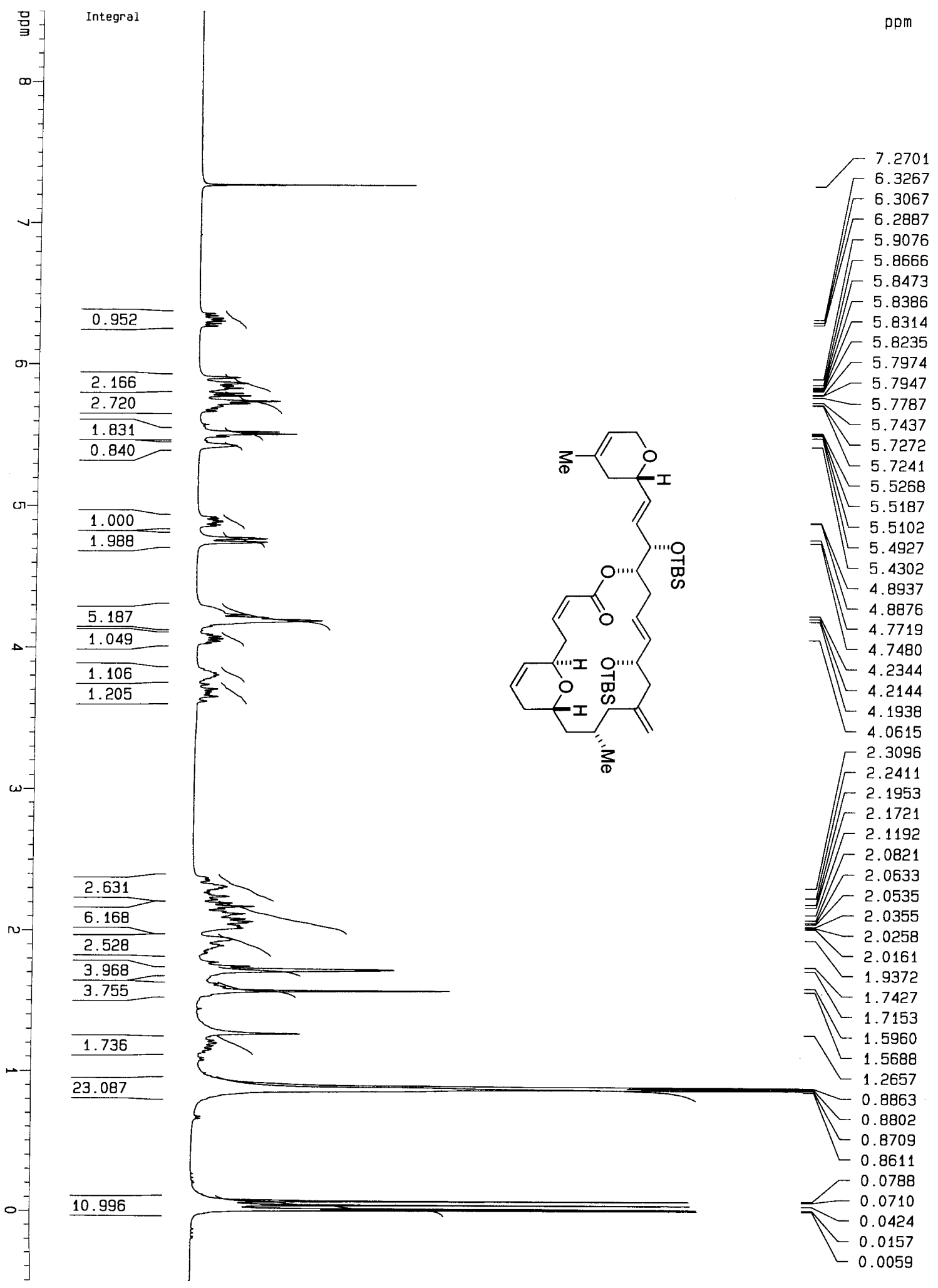




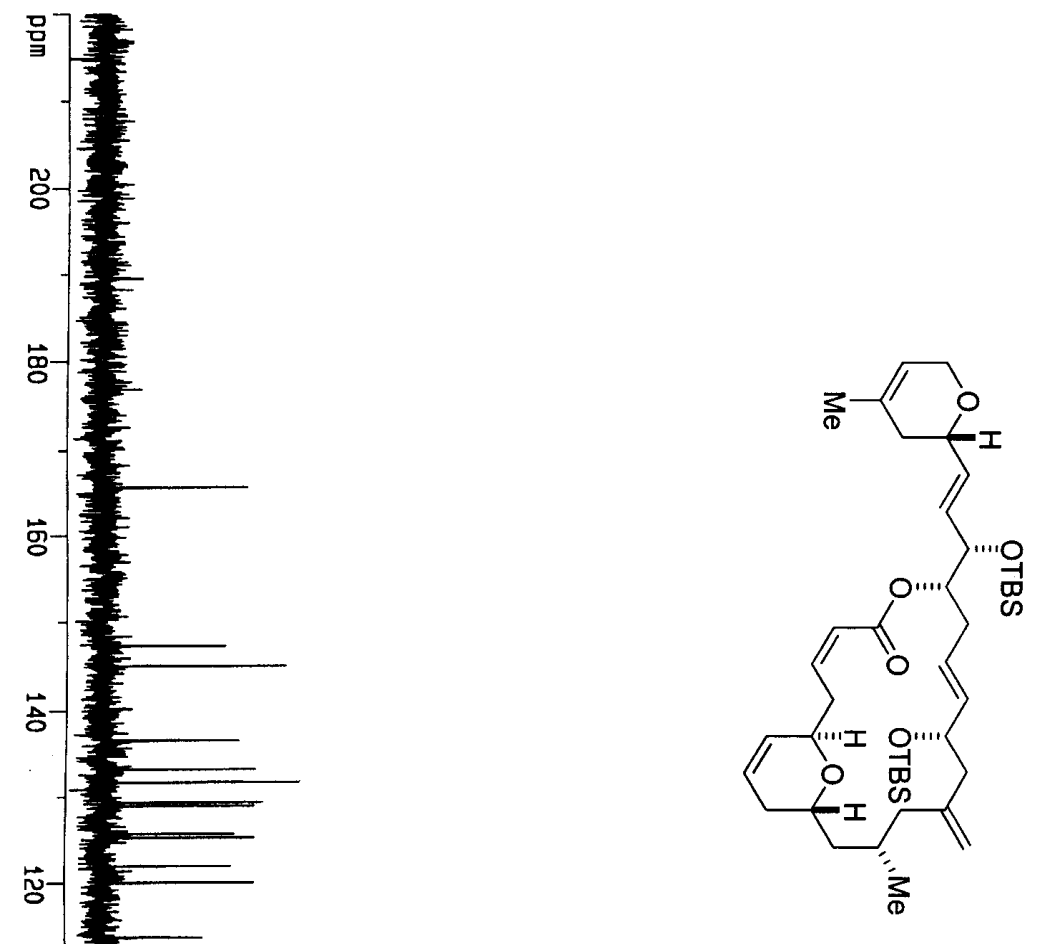

ppm

$-176.919$

165.599

$-147.351$

$-145.064$

136.581

133.121

$-131.656$

$-129.353$

$-128.945$

$-125.596$

$-125.232$

$-121.930$

$-120.052$

$-113.734$

F 78.773

$-78.210$

웅

号

- 77.739

77.516

- 77.317

- 76.893

76.676

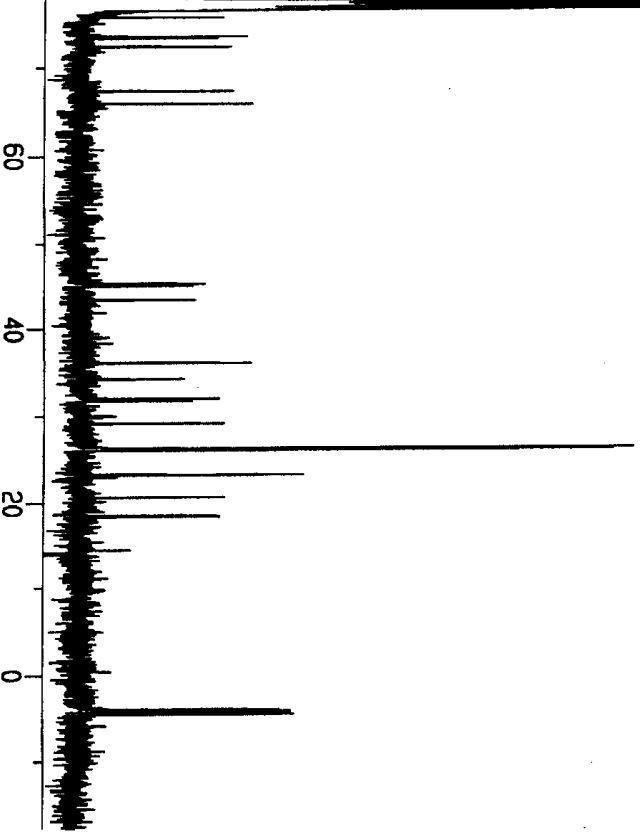

76.615

$-75.939$

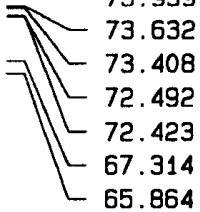

$-45.290$
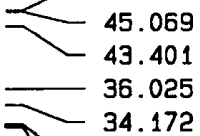

$\longrightarrow 31.939$

$7\left\lfloor\begin{array}{r}31.939 \\ 31.687\end{array}\right.$

L 29.130

$-26.207$

$L 26.059$

L 23.268

L 20.629

L 18.551

L 18.370

$-3.989$

$-4.185$

$\left[\begin{array}{l}-4.440 \\ -4.606\end{array}\right.$ 


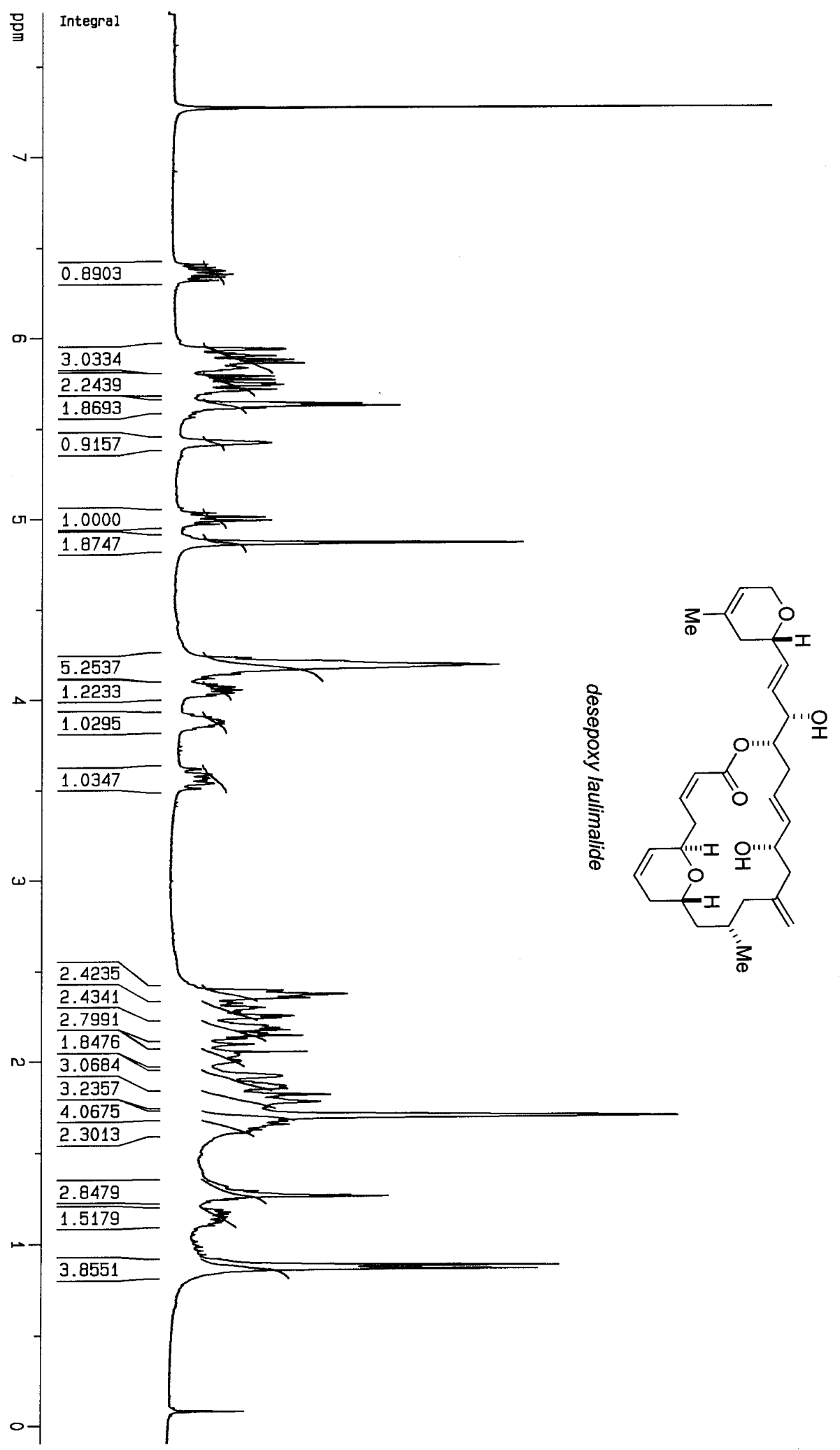

$-5.77253$

$7-5.76874$

$-5.74971$

$-5.74262$

5.71634

$-5.64138$

] -5.63330

$-5.62844$

$-5.42391$

$-5.01014$

$-4.99115$

כ -4.23008

$\checkmark 4.14080$

$-4.06791$

$-4.05200$

4.03504

$-3.87988$

-2.39292

$-2.37237$

$-2.35177$

$-2.29746$

$-2.25262$

$-2.24098$

$-2.19892$

$=-2.18423$

$\exists-2.17170$

$-2.15458$

$-2.14174$

引 -2.05347

$-1.92089$

ᄏ -1.86569

$-1.85210$

$-1.81947$

$7 L_{1.77988}$

$-1.70190$

$L_{1.67214}$

$7 L_{1.65514}$

$-1.29066$

- 1.26672

$L_{1.26028}$

-1.17204

$-0.88318$

$-0.86325$

$-0.07606$ 


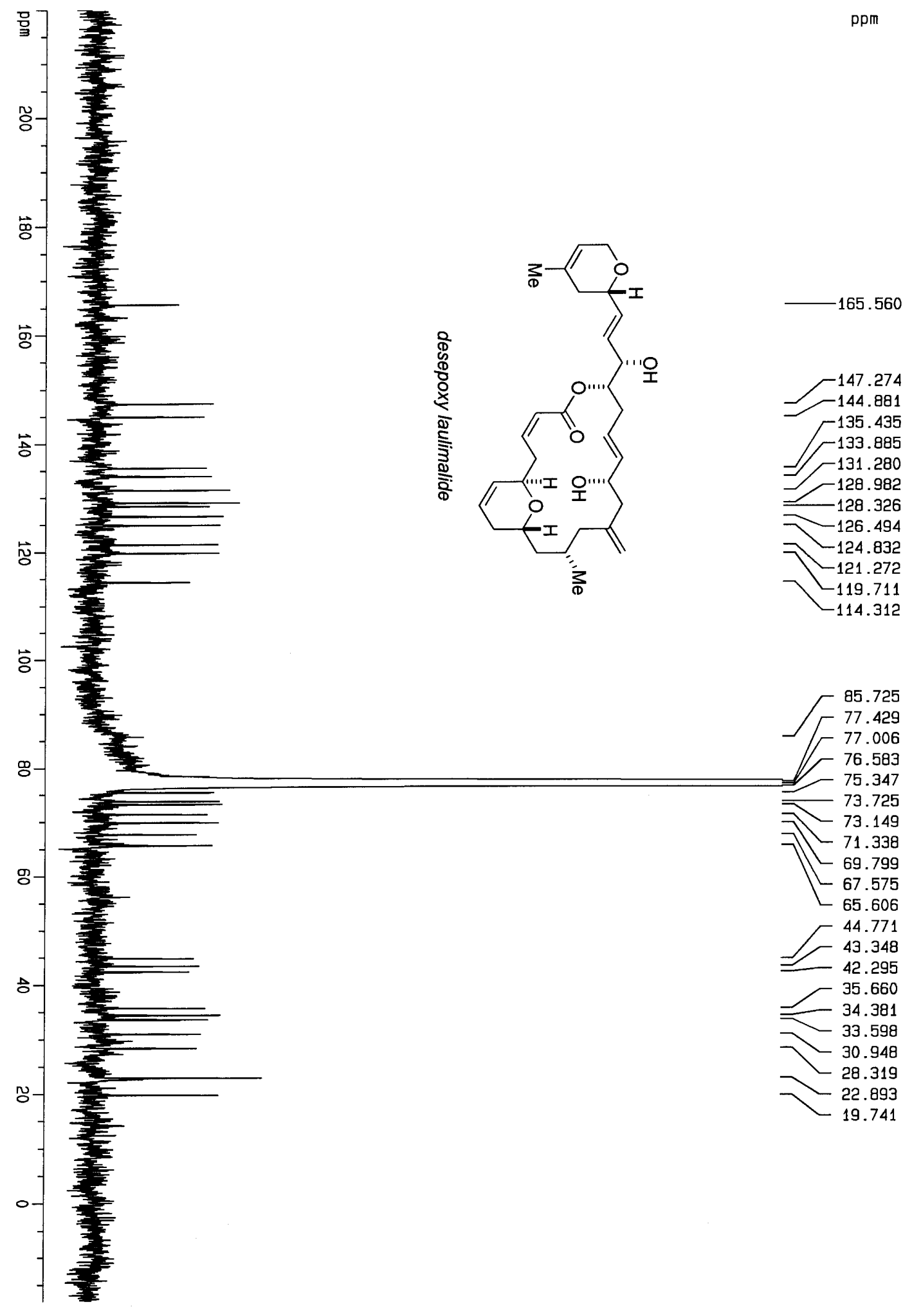



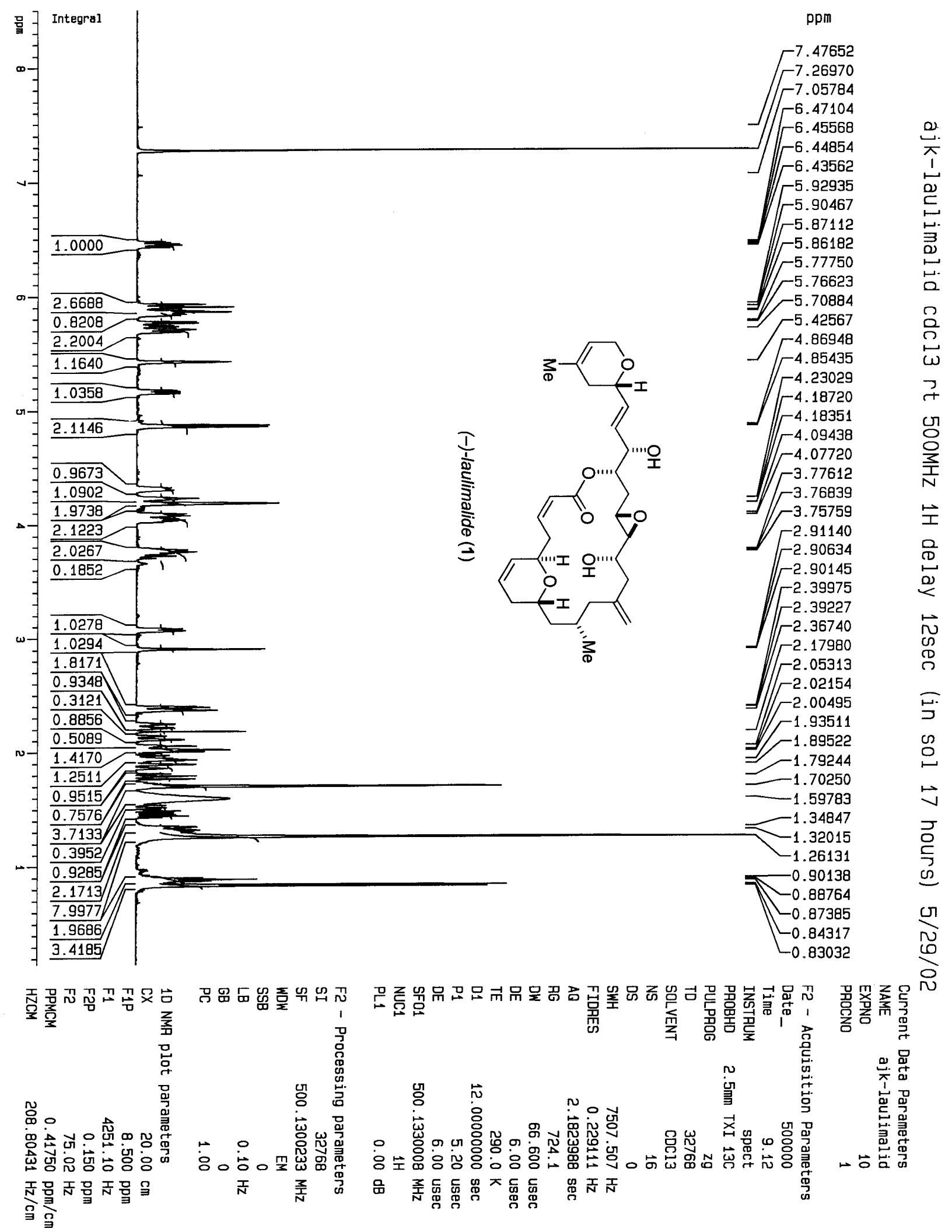


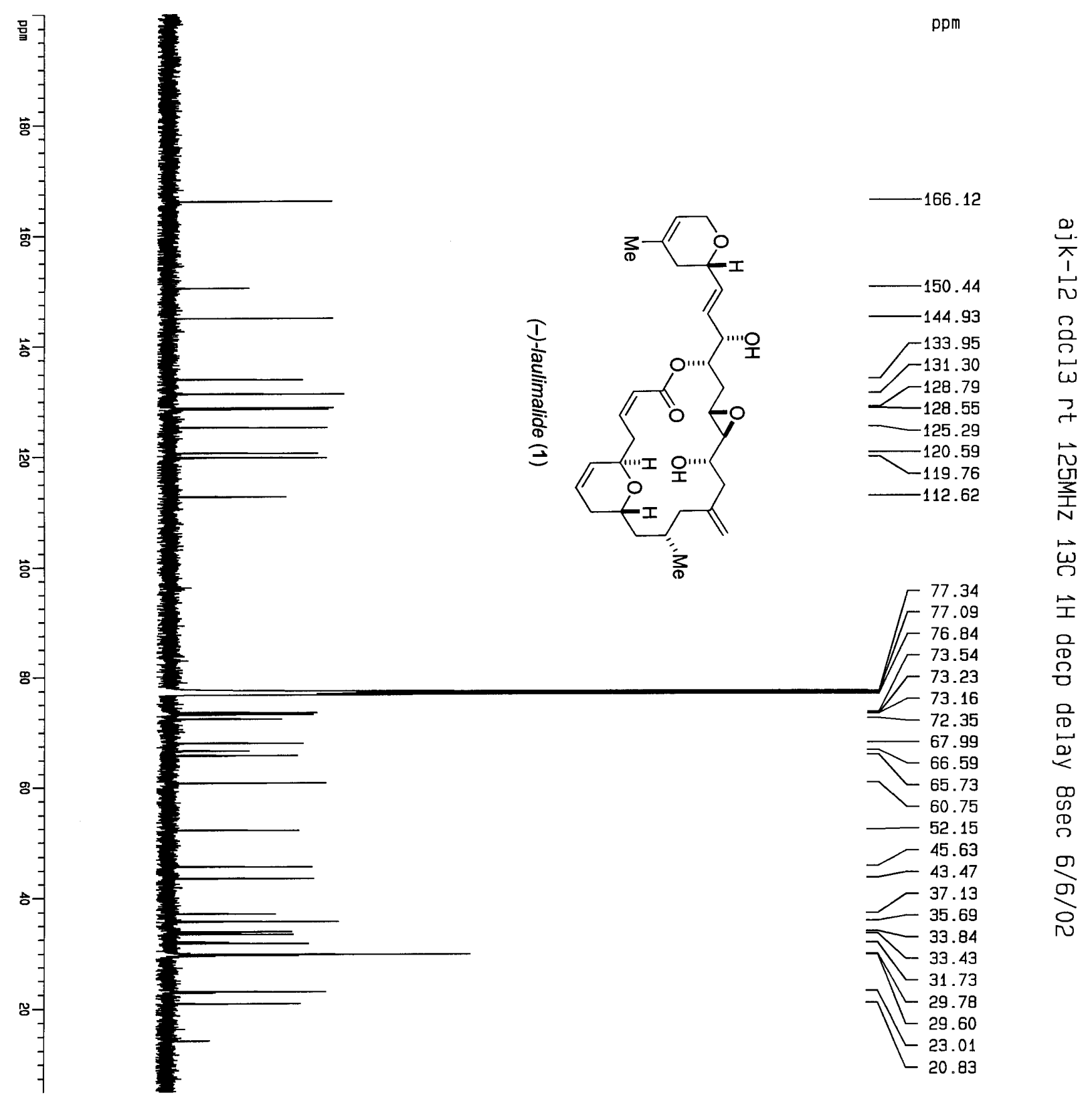

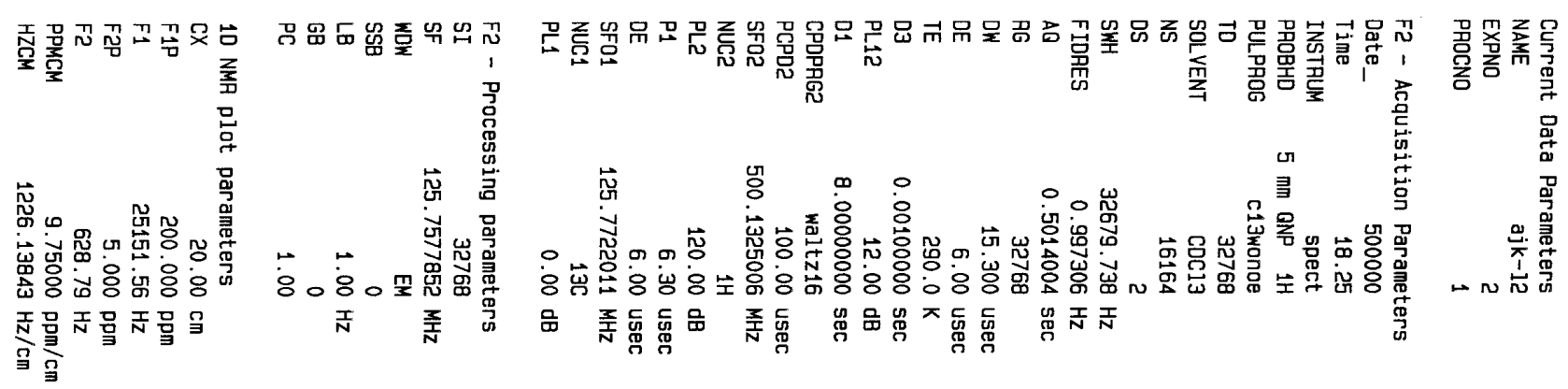

